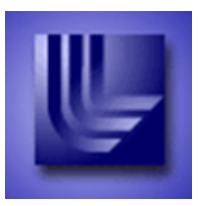

\title{
FINAL CLOSURE PLAN SURFACE IMPOUNDMENTS \\ CLOSURE, SITE 300 UCRL-SR-206943
}

The University of California

Lawrence Livermore National Laboratory

7000 East Avenue

Livermore, CA 94551 
FINAL CLOSURE PLAN

SITE 300 SURFACE IMPOUNDMENTS CLOSURE

LAWRENCE LIVERMORE NATIONAL LABORATORY

LIVERMORE, CALIFORNIA

UCRL-SR-206943

\author{
Submitted to: \\ Lawrence Livermore National Laboratory \\ 7000 East Avenue \\ L-654 P.O. Box 808 \\ Livermore, CA 94551
}

Submitted by:

Golder Associates Inc.

1009 Enterprise Way

Suite 350

Roseville, California 95678

Distribution:

(2) Copies LLNL

(1) Copy Golder Associates Inc.

February 2005

Project No. 043-7408 
This document was prepared as an account of work sponsored by an agency of the United States Government. Neither the United States Government nor the University of California nor any of their employees, makes any warranty, express or implied, or assumes any legal liability or responsibility for the accuracy, completeness, or usefulness of any information, apparatus, product, or process disclosed, or represents that its use would not infringe privately owned rights. Reference herein to any specific commercial product, process, or service by trade name, trademark, manufacturer, or otherwise, does not necessarily constitute or imply its endorsement, recommendation, or favoring by the United States Government or the University of California. The views and opinions of authors expressed herein do not necessarily state or reflect those of the United States Government or the University of California, and shall not be used for advertising or product endorsement purposes.

This work was performed under the auspices of the U.S. Department of Energy by University of California, Lawrence Livermore National Laboratory under Contract W-7405-Eng-48. 


\title{
(2) Goblder
}

\author{
FINAL CLOSURE PLAN \\ SITE 300 SURFACE IMPOUNDMENTS CLOSURE \\ LAWRENCE LIVERMORE NATIONAL LABORATORY \\ LIVERMORE, CALIFORNIA \\ UCRL-SR-206943
}

\author{
Submitted to: \\ Lawrence Livermore National Laboratory \\ 7000 East Avenue \\ L-654 P.O. Box 808 \\ Livermore, CA 94551
}

Submitted by:

Golder Associates Inc.

Golder Associates Inc.

1009 Enterprise Way

Suite 350

Roseville, California 95678
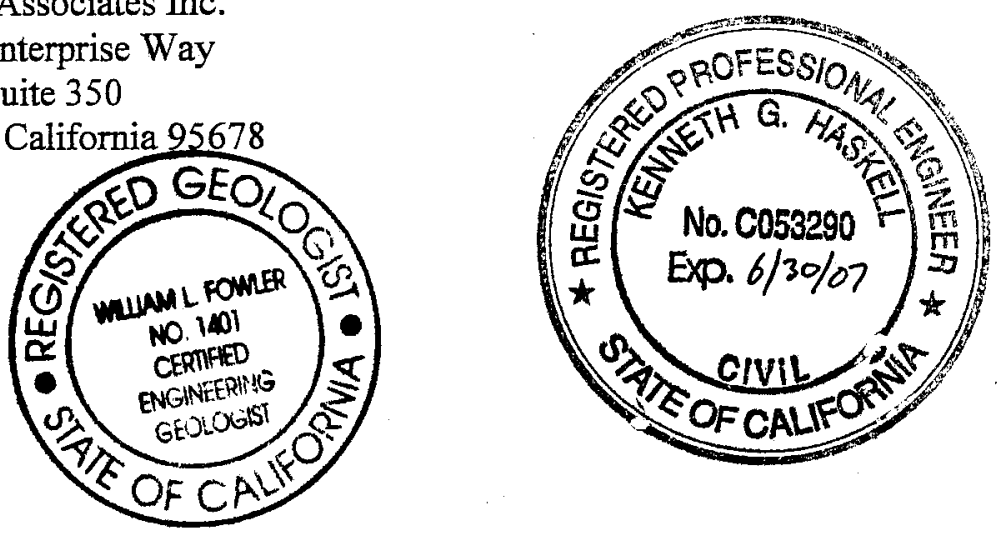

Maurent Maten

Maureen A. Mathias

Project Engineer

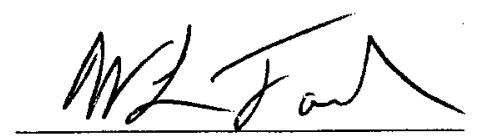

William L. Fowler, C.E.G.

Senior Consultant

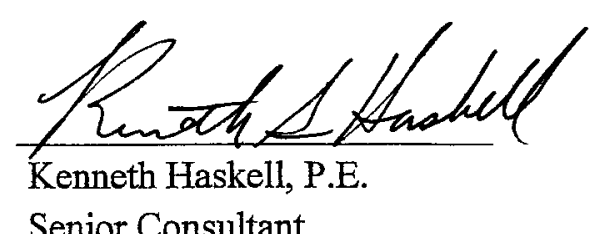

Senior Consultant

February 2005

043-7408 


\section{FINAL CLOSURE PLAN \\ SITE 300 SURFACE IMPOUNDMENTS CLOSURE}

\section{TABLE OF CONTENTS}

\section{Section}

Page

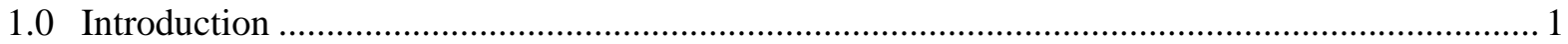

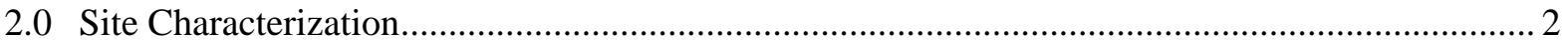

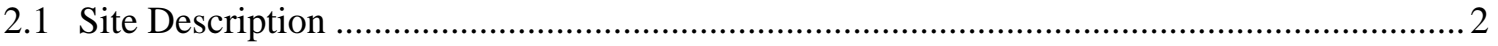

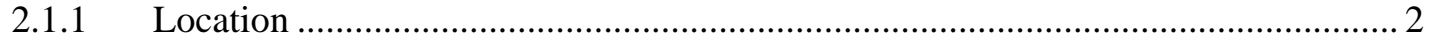

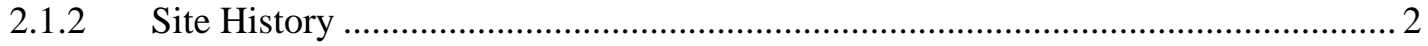

2.1.3 Current Operations .................................................................................... 2

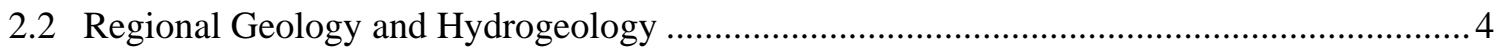

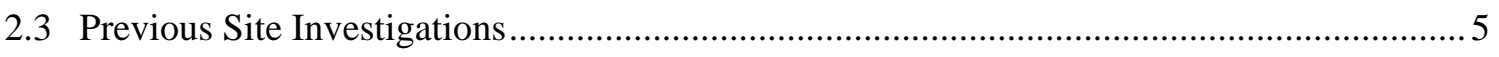

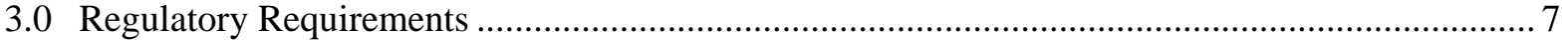

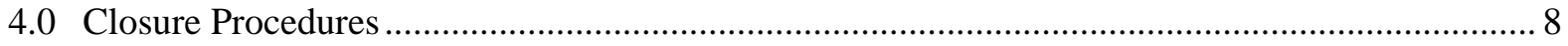

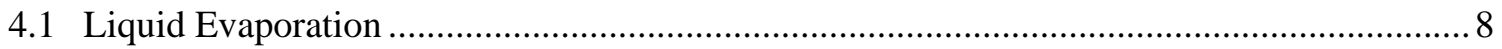

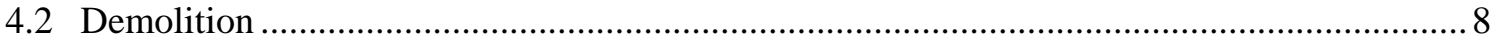

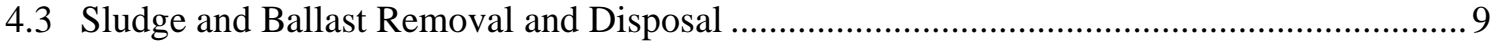

4.4 Geomembrane/Geotextile Removal and Disposal ........................................................... 9

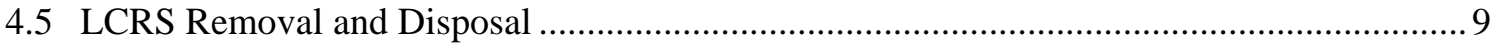

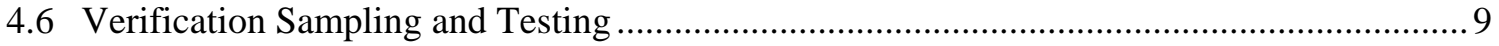

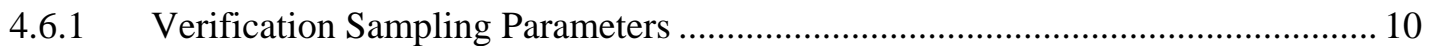

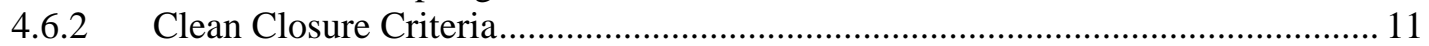

4.6.3 Clean Closure Contingency Plan ................................................................. 12

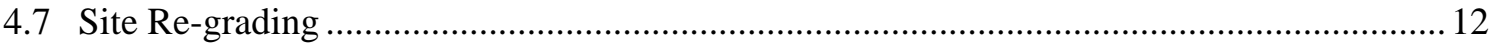

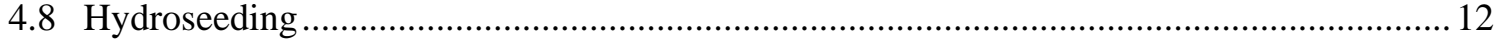

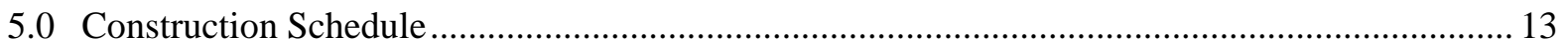

6.0 Postclosure Monitoring, Maintenance and Land Use.............................................................. 14

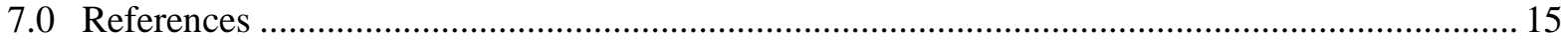


Site 300 Closure

\section{$\underline{\text { Tables }}$}

Table $1 \quad$ Wastewater Chemistry

Table 2 Sludge Chemistry

Table 3 Background Soils Chemistry and Screening Levels

Figures

Figure 1 Site Location Map

Figure 2 Site Plan

Figure 3 Existing Impoundments and Sampling Locations

Figure 4 Liner Section Schematic

Figure 5 Monitoring Well Locations

Figure $6 \quad$ Pre-existing Contaminant Source Areas and Drinking Water Wells

Figure $7 \quad$ Conceptual Closure Grades

Figure $8 \quad$ Conceptual Closure Sections

Figure 9 Construction Schedule

$\underline{\text { Appendices }}$

Appendix A Discharge Wastewater Chemistry, Spring Chemistry, and Constituents of Concern

Appendix B Sampling and Analysis Plan

Appendix C Construction Plans

Appendix D Construction Specifications 


\section{FINAL CLOSURE PLAN \\ SITE 300 SURFACE IMPOUNDMENTS CLOSURE}

\subsection{INTRODUCTION}

Lawrence Livermore National Laboratory of the University of California (LLNL) operates two Class II surface impoundments that store wastewater that is discharged from a number of buildings located on the Site 300 Facility (Site 300). The wastewater is the by-product of explosives processing. Reduction in the volume of water discharged from these buildings over the past several years has significantly reduced the wastewater storage needs. In addition, the impoundments were constructed in 1984, and the high-density polyethylene (HDPE) geomembrane liners are nearing the end of their service life. The purpose of this project is to clean close the surface impoundments and provide new wastewater storage using portable, above ground storage tanks at six locations. The tanks will be installed prior to closure of the impoundments and will include heaters for allowing evaporation during relatively cool weather.

Golder Associates (Golder) has prepared this Final Closure Plan (Closure Plan) on behalf of LLNL to address construction associated with the clean closure of the impoundments. This Closure Plan complies with State Water Resources Control Board (SWRCB) Section 21400 of the California Code of Regulations Title 27 (27 CCR §21400). As required by these regulations and guidance, this Plan provides the following information:

- A site characterization, including the site location, history, current operations, and geology and hydrogeology;

- The regulatory requirements relevant to clean closure of the impoundments;

- The closure procedures; and,

- The procedures for validation and documentation of clean closure. 


\subsection{SITE CHARACTERIZATION}

\subsection{Site Description}

\subsubsection{Location}

Site 300 occupies 11 square miles in the Altamont Hills approximately 8.5 miles southwest of Tracy, California and 15 miles southeast of Livermore, California (as shown on Figure 1). The property is owned by the United States Government (CVRWQCB, 1996).

Surface water from Site 300 drains to Corral Hollow Creek, an ephemeral stream which drains east toward the San Joaquin River basin. The source of surface water is runoff from infrequent heavy rains. Beneficial uses of groundwater in the vicinity of Site 300 are domestic, agricultural, and industrial supply. Site 300 receives an average of 10 inches of precipitation per year based on measurements at the Site 300 weather station from 1965 to 1992. The mean evapotranspiration is 54 inches per year. The facility is not within a 100-year flood plain (CVRWQCB, 1996).

\subsubsection{Site History}

The area now occupied by Site 300 was used for livestock grazing and ranching prior to development in 1955. In the late 1950s, a portion of the facility was developed for processing high explosives. Technical operations in this area included chemical formulation, mechanical pressing, and machining of high explosive compounds into shaped detonation devices, which were used in open-air detonation experiments. Solid waste from machining operations was incinerated at an Open Burn Facility located near Building 829 within the northern portion of the explosives area. Liquid waste was discharged to former unlined disposal lagoons (E. Raber, 1983). The unlined disposal lagoons were closed in 1985 under the jurisdiction of the CERCLA program (V. Madrid et al., 2002).

Sampling and analysis of on-site water supply well 6 indicated that trichloroethylene (TCE), a volatile organic compound (VOC), was leaching into the site's groundwater. The well was destroyed in March 1989 and replaced with water supply well 20, located in another area on-site. In 1984, two double-lined surface impoundments were installed in the explosives area (Figure 2). The impoundments allow dissolved explosives chemicals in process wastewater to degrade from exposure to ultraviolet rays in sunlight (V. Madrid et al., 2002). The surface impoundments are regulated by Waste Discharge Requirements (WDR) 96-248. Further detail on construction of the impoundments is provided in Section 2.1.3.1.

The Open Burn Facility was dismantled and capped following the 1997 Final Closure Plan (Lamarre et al. 1997). Three deep groundwater monitoring wells were installed for Postclosure monitoring (V. Madrid et al., 2002). Further detail on previous investigations conducted at the site is provided in Section 2.3.

\subsubsection{Current Operations}

The surface impoundments are currently being used to receive discharge wastewater from three processing areas within Site 300:

- The Explosives Processing Area;

- The Photo Process Area (formerly called Radiography Area); and,

- $\quad$ The Chemistry Area. 
Figure 2 shows the general layout of Site 300, including the three areas that discharge water to the impoundments, and Figure 3 shows the existing impoundments. LLNL staff is working with the U.S. Fish and Wildlife Service to determine if this project may affect threatened or endangered species, and if necessary, to coordinate protection of sensitive species and habitats prior to proceeding with the closure project.

The following sections provide further descriptions of the construction of the impoundments and the chemistry of the water and sludge within the impoundments.

\subsubsection{Surface Impoundments}

The surface impoundments were constructed in 1984 with the following components from top to bottom:

- A 1-foot thick layer of sand ballast;

- A 60-mils thick high-density polyethylene (HDPE) geomembrane;

- A layer of sand for the leachate collection and removal system (LCRS);

- A 2-foot thick compacted clay liner on the floor (4-foot thick on the side slopes); and,

- Soil subgrade.

Figure 4 shows a typical section of the liner. A leachate collection and removal system (LCRS) consisting of two-inch diameter slotted PVC pipes was installed at the base of the sand layer underlying the geomembrane. In addition, eight lysimeters (four in the upper pond and four in the lower pond) were installed for collection of fluid from below the clay liner. The lysimeters are not compliance monitoring points and have, in general, not functioned effectively. An experimental electrical resistivity leak detection system was also installed in the impoundment berms (i.e., a series of electrodes installed in traffic boxes).

During the lifetime of the impoundment operations, several liner defects have been identified and repaired. In 1990, leakage was discovered around the 12-inch-diameter PVC interpond conduit located on the south side of the upper impoundment (Emcon Associates, 1990a) (Figure 3). A prefabricated boot was installed to repair the leak (Emcon Associates, 1990b). In 1996, three liner defects were identified in the upper impoundment using electrical leak location methods (Leak Location Services, 1996). One defect was in the northwestern corner, one was noted in the northeastern corner, and one was located in the south central portion of the pond (Figure 3). The defects were subsequently repaired (Pers. Comm., K. Folks, 2004). In 1999, an experimental electrical resistivity survey indicated a liner defect in the northwestern corner of the upper impoundment, and liner defect near the wooden platform located in the lower pond (Daily and Ramirez, 1999). The defects were subsequently repaired (Pers. Comm., K. Folks, 2004).

In addition to the above liner defects, there have also been defects observed in the liner above the high liquid levels of the impoundments. The defects have been repaired over time as they have been discovered (Pers. Comm., K. Folks, 2004).

\subsubsection{Wastewater and Sludge Chemistry}

Wastewater from the surface impoundments was tested in 1995 and most recently in 2003, and sludge was tested in 2002 (Tables 1 and 2). The analytical results from the wastewater and sludge provide important data regarding the chemistry of the waste in the pond, how it compares and contrasts to the chemistry of the wastewater effluent to the impoundments from the processing areas (discussed in 
Section 2.1.3), and what contaminants might be expected with potential leakage from the impoundments. A qualitative review of the data indicates:

- Soluble metals from the sludge are below reporting limits except for Barium which was detected well below background levels in soil for Site 300 (background soil screening values for soluble and total metals from internal LLNL study performed on uncontaminated soils in 1995);

- Total metals analyses indicate elevated levels of Chromium, Cobalt, Nickel and Vanadium (as compared with background soil screening values) were present in the sludge from the lower surface impoundment. The first three metals are constituents of concern (COCs) for the surface impoundment groundwater monitoring program, whereas Vanadium is not a COC. It is also noted that the total metals analyses involved a digestion of sorbed metals from the solid fraction of the sludge and may not be representative of fluids that may have leaked through the liner;

- Low level detections of dinitrotoluene compounds were observed in the sludge samples;

- No volatile or semi-volatile organic compounds were detected in wastewater;

- Both wastewater and sludge show elevated levels of inorganic salts (as compared with wastewater effluent values into the ponds) associated with evaporation of water from the ponds and concentration of the salts; and,

- Arsenic, Barium, Chromium, Copper, Lead, Potassium, Silver and Zinc were all consistently detected (i.e., in almost all analyses) in the dissolved state in the impoundment wastewater.

\subsection{Regional Geology and Hydrogeology}

Site 300 is located in an area of steep northwest-southeast trending ridges and canyons that drain to the southeast. The area is underlain by Quaternary alluvial deposits from the Corral Hollow Creek drainage, Quaternary terrace deposits, Pliocene non-marine deposits (Tps), and Miocene bedrock units of the Neroly Formation.

The Quaternary deposits situated along the drainage course of Corral Hollow Creek consist mainly of unconsolidated sand and gravel alluvial deposits ranging up to 30 feet in thickness. The Quaternary terrace and Pliocene deposits primary consist of sand, silt, clay, and gravel ranging up to 100 feet in thickness. (V. Madrid et al., 2002). These units are variably saturated throughout the Explosives Processing Area and contain isolated, perched water-bearing zones.

Below the Quaternary and Pliocene deposits, there is over 400 feet of interbedded sandstone, siltstone, claystone, and conglomerates of the Neroly Formation, which has been divided into different regional stratigraphic units. There are two sandstone aquifers within the units, the Neroly Upper Blue Sandstone $\left(\mathrm{Tnbs}_{2}\right)$ and Neroly Lower Blue Sandstone $\left(\mathrm{Tnbs}_{1}\right)$. The Tnbs 2 aquifer ranges in thickness from 50 to 60 feet, while the Tnbs ${ }_{1}$ aquifer is 200 to 250 feet thick. A 100-foot-thick confining layer appears to hydraulically separate the Tnbs 2 from Tnbs 1 (V. Madrid et al., 2002).

The surface impoundments are underlain by an unsaturated zone ranging from 70 to over 130 feet thick. There are two water-bearing zones that occur beneath the impoundments: the Tps perched groundwater, and the $\mathrm{Tnbs}_{2}$ bedrock aquifer. Shallow ground water in the Tps unit occurs as localized, hydraulically isolated, perched water-bearing zones. These zones are recharged naturally by direct infiltration from rainfall and artificially through various forms of discharge from nearby 
buildings and sources such as boiler system blow down, septic systems, former HE lagoons, former dry wells, etc. The main form of discharge from Tps perched water-bearing zones is via springs (e.g., Spring 5 which discharges immediately below the impoundments) and through evapo-transpiration on nearby hillslopes. Typical Tps hydrographs exhibit 2 to 10 feet of water elevation rise in response to seasonal rainfall events (V. Madrid et al., 2002). Spring 5 was sampled and analyzed four times from October 1993 through June 1996 for many of the COCs required by WDR 96-248 (Appendix A). An additional sampling event for volatile organic compounds (VOCs) was also conducted in 1997. No energetic materials, or other anthropogenic materials were detected. Metals were generally below reporting limits or statistically based limits.

In the area of the impoundments, groundwater in the $\mathrm{Tnbs}_{2}$ is unconfined and is encountered at approximately 620 feet MSL (approximately 130 feet bgs). The primary source of recharge to the $\mathrm{Tnbs}_{2}$ aquifer is through infiltration along northwest-trending canyons where this aquifer is exposed. The main discharge for this aquifer is into the overlying alluvial aquifer, along the eastern flank of the Lone Tree syncline, where the $\mathrm{Tnbs}_{2}$ aquifer occurs beneath the alluvial aquifer. Under unstressed, natural flow conditions, $\mathrm{Tnbs}_{2}$ water levels in this discharge area are higher than water levels in the overlying alluvial aquifer, indicating an upward hydraulic gradient (V. Madrid et al., 2002).

Further details on the hydrogeology of the Explosives Processing Area is provided in the report Interim Remedial Design for the High Explosives Process Area Operable Unit at Lawrence Livermore National Laboratory Site 300 (V. Madrid et al., 2002).

\subsection{Previous Site Investigations}

A site investigation began in the early 1980s to evaluate whether wastewater discharges into the unlined lagoons resulted in contamination of the local groundwater. The investigation indicated that the lagoon waters contained concentrations of chemical explosives cyclo-1,3,5-trimethylene-2,4,6trinitramine (RDX), cyclotetramethylene tetranitramine (HMX), and trinitrotoluene (TNT) in the parts per million (ppm or milligrams per liter, $\mathrm{mg} / \mathrm{L}$ ) range. Barium was detected at $2.35 \mathrm{mg} / \mathrm{L}$ in one lagoon, and nitrate was detected at concentrations exceeding the $45 \mathrm{mg} / \mathrm{L}$ drinking water standard in three lagoons. The study concluded that discharges to the lagoons would reach groundwater within 20 years (E. Raber, 1983).

Additional investigations followed to determine the nature and extent of soil and groundwater contamination beneath the site. The additional investigations included collection and analysis of surface soil samples, subsurface soil and bedrock samples, water samples, soil vapor samples, and the installation of groundwater monitoring wells. The investigations resulted in identifying VOCs (including TCE), high explosives compounds (including HMX, RDX, and Perchlorate), and nitrate as the primary COCs in groundwater. (V. Madrid et al., 2002). An extensive system of groundwater monitoring wells has defined the contaminant plumes and provides for ongoing monitoring of plume migration (Figure 5).

Contamination in the soil and bedrock of the Explosives Processing Area (specifically in the area of buildings 806, 807, 809, 817) includes HMX and RDX at concentrations up to $29 \mathrm{mg} / \mathrm{kg}$, TCE at concentrations up to $0.24 \mathrm{mg} / \mathrm{kg}$, and leached barium at concentrations up to $28 \mathrm{mg} / \mathrm{L}$. (V. Madrid et al., 2002). Passive and active soil vapor surveys detected VOCs, including low concentrations of TCE $(<0.1 \mathrm{ppm})$.

In summary, twelve confirmed chemical release sites (source areas) have been identified to date. Among the confirmed release sites, the former TCE Hard Stand located near Building 815 is considered to be the primary source of VOCs. The HE rinse-water disposal lagoons at Buildings 806/807 and 817, and the dry well at Building 810, are considered the primary source areas for HE 
compounds, including perchlorate and nitrate (Figure 6) (V. Madrid et al., 2002). Groundwater underlying the surface impoundments is on the southwestern fringe of the identified RDX and Perchlorate plumes, and is not currently impacted with TCE. 


\subsection{REGULATORY REQUIREMENTS}

Golder developed this Closure Plan following the closure requirements for Class II surface impoundments referenced in 27 CCR §21400 and §21769. These regulations specify:

- Removal of all free liquids remaining in the surface impoundments at the time of closure;

- Discharge of all free liquids at an approved waste management unit;

- Removal of all contaminated wastes, including sludges, precipitates, settled solids, and liner materials contaminated by waste;

- Discharge of all contaminated waste to an approved waste management unit;

- Inspection of all remaining containment features for contamination;

- Dismantling of remaining containment features that are found to be free of contamination;

- Removal of contaminated natural geologic materials surrounding the closed impoundments;

- Disposal of contaminated natural geologic materials at an appropriate waste management unit;

- Notification of the RWQCB 180 days prior to closure construction and within 30 days upon completion; and,

- Successful completion of clean-closure eliminates the need for Postclosure maintenance. 


\subsection{CLOSURE PROCEDURES}

Clean closure of the surface impoundments will require evaporation of liquid from the impoundments, excavation and disposal of any sludges and the sand ballast, demolition and disposal of appurtenant above-ground structures (e.g., stairs, railings, lysimeters, etc.), removal and disposal of the geomembrane liner and LCRS sand layer, and removal and disposal of pond-related piping. The clay layer will be sampled for chemical constituents to determine whether it can remain in place, or if areas of the clay liner need to be removed. Samples will also be collected from the soils underlying the clay liner to determine if contaminated water has leaked through the liner into these materials. Once sampling has verified that the chemical constituents of concern have been removed, the impoundments will be re-graded to provide positive drainage. This will entail excavation of the existing outer embankments and replacement as engineered fill in the former ponds to establish positive grades.

Each element of the closure project is described in further detail below.

\subsection{Liquid Evaporation}

The project schedule will be managed so that liquids in the pond will be allowed to evaporate, and that no liquid removal and disposal will be required. It is anticipated that the tank construction project will be complete, and discharges to the ponds will be discontinued by late April 2005 . It is estimated that the ponds will be dry by late June, and clean closure activities will commence in late June or early July 2005. Prior to the start of construction, LLNL personnel will monitor the ponds and provide dust control by wetting as needed. In the event that all liquids cannot be evaporated, then the liquids will be pumped from the impoundments by the subcontractor, tested for discharge limit parameters (see Sampling and Analysis Plan, Appendix B), and disposed under the auspices of LLNL's sewer permit (Wastewater Discharge Permit \#1250, issued by the City of Livermore Water Resources Division), or at an alternate approved waste management unit.

\subsection{Demolition}

Prior to start of grading, various appurtenant structures associated with the impoundments will be demolished and removed, and disposed at an approved waste management unit (Class II or Class III). Identified structures include, but are not necessarily limited to:

- Concrete stairs with galvanized steel railings;

- Lysimeter control boxes, valves, etc.;

- Traffic boxes (valves, electrical leak detection leads, etc.);

- Galvanized steel frame located in upper pond;

- Wooden stairs in lower pond; and,

- Concrete vault box for LCRS piping.

Subsurface piping, wiring, etc. associated with the above ground vault boxes will also require removal and disposal. The subcontractor shall be responsible for determining appropriate equipment, methods and procedures for removal of subsurface piping. LLNL and/or its authorized representative shall approve the proposed methods and equipment. 


\subsection{Sludge and Ballast Removal and Disposal}

Prior to excavation of waste materials, the subcontractor shall construct an equipment decontamination area within the approved project containment area. Any equipment coming in contact with waste materials shall be decontaminated prior to leaving the project containment area to prevent the spread of waste materials outside the containment area. Decontamination requires a steam cleaner pressure wash, or an approved alternate method. All rinse water shall be contained for disposal under the auspices of the permit issued by the Livermore Water Reclamation Plant for discharges to the sanitary sewer system at the Livermore site. LLNL may require analytical testing of the rinse water prior to disposal.

Prior to excavation of the sludge and sand ballast, the construction area will be prepped for dust control either by wetting or by application of tackifier or a similar method. The specific method and materials for dust control will be decided upon by the subcontractor and approved by LLNL and/or their authorized representative.

It is anticipated that approximately 240 cubic yards (cy) of sludge will be removed from within the impoundments, along with approximately 1050 cy of sand ballast that lies on top of the geomembrane. The subcontractor will determine an appropriate method and equipment for removal of the ballast and sludge. The methods and equipment shall be approved by LLNL and/or their authorized representative. Based on the estimated volume above, six to eight composite grab samples will be collected from the excavated sludge and sand ballast (i.e., a minimum of four composite samples for every 750 cy based on typical soil acceptance requirements at Class II disposal facilities). The composite samples will be submitted for appropriate analytical testing to demonstrate the material is non-hazardous (as specified by the selected disposal facility). The sampling and analytical testing program is discussed in more detail in the Sampling and Analysis Plan (Appendix B).

\subsection{Geomembrane/Geotextile Removal and Disposal}

Upon completion of the removal of the sludge and sand ballast, the HDPE geomembrane and underlying geotextile will be removed. The subcontractor will be responsible for determining an appropriate method and equipment for removal of the HDPE and geotextile. Proposed methods and equipment shall be approved by LLNL and/or their authorized representative. The geomembrane and geotextile will be disposed of at the selected disposal facility. It is assumed that the geomembrane and geotextile will meet disposal requirements based on the results from the sludge/ballast testing, however, this will be confirmed prior to disposal.

\subsection{LCRS Removal and Disposal}

It is anticipated that approximately 1,425 cy of sand from the leachate collection and removal system will be removed from within the impoundments. The analytical results of the sludge and sand ballast will be used to characterize this sand for disposal at the selected disposal facility.

\subsection{Verification Sampling and Testing}

The clay liner will be inspected for visual evidence of contamination, and sampled and analyzed to determine if leaks through the geomembrane have contaminated the clay above acceptable levels. Samples from the native soils underlying the clay liner will also be collected and analyzed to verify the integrity of the lining system.

A minimum of 16 samples (total) will be analyzed from the clay liner in the upper and lower impoundments. Five samples are proposed near known areas of leakage in both the upper and lower impoundments. The remaining eleven samples are distributed to give areal coverage of the liner in 
both impoundments. Figure 3 shows the distribution of the 16 total sample in the upper and lower impoundments.

A minimum of six samples (total) will be analyzed from the native soils underlying the liner in the upper and lower impoundments. The subcontractor will be responsible for providing a backhoe and operator to work with the LLNL personnel to excavate the test sample locations. The Sampling and Analysis Plan (Appendix B) provides further details on the sampling locations, depths, and sample handling procedures. The proposed verification sampling parameters and criteria for clean closure are described in more detail below.

\subsubsection{Verification Sampling Parameters}

Clean closure indicator parameters for the clay liner and underlying soils will consist of a select list of "indicator parameter" COCs from the existing discharge wastewater monitoring program currently required by the WDR 96-248. In addition, data provided from analytical testing of impounded water and sludge that was conducted in 2002 was also evaluated and considered in the selection of the indicator parameters. The intent of the indicator parameters is to test for known waste constituents that are persistent (i.e., not subject to rapid degradation), and that would be indicative of a release. Based on these criteria, the recommended list of indicator monitoring parameters for the clean closure activities consist of:

- $\quad$ Barium, Total in Soil (USEPA Method 6010B);

- Chromium, Total in Soil (USEPA Method 6010B);

- Nickel, Total in Soil (USEPA Method 6010B);

- Zinc, Total in Soil (USEPA Method 6010B);

- $\quad$ Chloride, Total in Soil (USEPA Method 300.0);

- Sulfate, Total in Soil (USEPA Method 300.0); and,

- RDX/HMX (USEPA Method 8330).

In general, the heavy metals and the HE compounds are the primary constituents of concern that are detected in the effluent waste streams. Barium, Chromium, Nickel, and Zinc are frequently detected above reporting limits (RLs) in the effluent, and were also detected at elevated levels in sampling of the sludge contained in the wastewater ponds. In addition, Chromium and Nickel concentrations have exceeded their statistically based limits in site groundwater samples. Although other metals are detected in the effluent waste streams and the impoundment wastewater (e.g., Arsenic, Cadmium, Cobalt, Copper, Lead, Manganese, Molybdenum, Potassium, Silver and Vanadium), these metals generally occur at lower concentrations relative to RLs, were not detected in sludge samples, and have not been observed above statistically based limits in site groundwater samples. In summary, Barium, Chromium, Nickel, and Zinc are believed to represent a suitable and representative suite of the metals present in the effluent wastewater stream and impoundment wastewater, and are therefore recommended as indicator parameters for the trace heavy metals.

Concentrations of RDX/HMX have been consistently detected in wastewater discharged to the impoundments. Although these compounds do degrade fairly rapidly, there were trace detections in the sludge from the impoundments. Because these compounds are anthropogenic, and are ubiquitous in the wastestream, it is recommended that they be used as indicator parameters. 
Although the inorganic salts are not part of the COC list for the effluent discharge, evaporation processes associated with the impoundments have resulted in elevated concentrations of inorganic salts in the wastewater and sludge. Therefore it is recommended that chloride and sulfate be used as representative indicator parameters for the inorganic salts.

No testing is proposed for volatile or semi-volatile compounds since they have generally not been detected in effluent samples and they would be subject to rapid volatilization and/or degradation in the impoundments. No testing is proposed for the nitrogen compounds (nitrate, ammonia, and TKN) since they are not COCs, and the general geochemical complexity of the impoundments would make it very difficult to evaluate the resulting data. In addition, there is no available background data for site soils, and there is a recognized widespread presence of nitrogen compounds in the Explosives Processing Area.

\subsubsection{Clean Closure Criteria}

Clean closure will be considered complete if the verification samples from the clay liner have concentrations less than or equal to background concentrations from the clay liner background testing program and/or established site background concentrations for heavy metals in soil (Table 3). Should concentrations from the samples collected from the upper portion of the clay liner exceed background concentrations, samples collected from the lower portion of the clay liner will be submitted for laboratory analyses.

The clay liner will be removed to the depth at which concentrations in the clay exceed background concentrations. For example, if there is contamination found in the samples collected from the upper clay liner (0 to 6 inches), and no contamination is found in the samples collected from the lower portion of the clay liner (12 to 18 inches), the upper foot of the clay liner will be removed within that area. If contamination is found in samples from both depths, the entire 2-feet of clay will be removed from that area. As with the overlying layers, the clay removed from the impoundments will be subject to analytical testing prior to disposal at an approved facility.

Six (6) background samples for the clay will be collected from the clay liner at locations around the top of the impoundments above the high wastewater elevation. These samples will be analyzed for the verification sampling parameters using the test methods presented above. Background sampling will be conducted prior to the start of clean closure activities.

Six (6) samples from the native soils underlying the clay liner will also be tested for the verification sampling parameters. The concentrations will be compared against established site background concentrations for heavy metals in soil (Table 3). No suitable background is available for chloride or sulfate in soil, consequently they are not recommended as verification parameters for the native soils.

If exceedances of background for naturally occurring inorganics (i.e., metals) are observed in native soils, then additional testing will be performed to determine if there is a potential threat to groundwater. The Designated Level Methodology (DLM) (CRWQCB, 1986) will be utilized to determine if water percolating through the subgrade soils will exceed the lowest water quality objective for each COC. For this application, it is recommended that the extraction be preformed using de-ionized water since the future source of any percolation through native soils is naturally occurring rainfall. Although there is no background concentration for RDX and HMX, the DLM would also be performed for RDX and HMX to determine the threat to groundwater if they were detected. The analytical parameters, methods, and reporting limits are discussed in further detail in the Sampling and Analysis Plan (Appendix B). 


\subsubsection{Clean Closure Contingency Plan}

In the event that concentrations of verification parameters collected from the soils underlying the clay liner exceed background concentrations and the DLM indicates that water percolating through the subgrade soils will exceed the lowest water quality objective for the subject COCs, it is recommended that the full list of COCs applicable to the effluent and LCRS (Tables 3 and 6, M\&RP 96-248 (Appendix A)) be performed to evaluate whether: 1) the contamination is associated with pond leakage or, 2) is related to prior activities in the Explosives Processing Area. If the contamination is localized and clearly related to leakage from the ponds (e.g., one or two locations), then limited overexcavation and re-sampling is recommended to remove the contamination. In this case, the lateral extent and depth of over-excavation will be proposed to the RWQCB for concurrence and approval.

If the contamination is limited in depth (less than five feet) and aerial extent, then over-excavation of the pond area may be warranted. However, if contamination in the native soils appears to occur over a large area, and/or extends to depths exceeding five feet below the base of the liner system (i.e., below bottom of clay liner), it is recommended that LLNL (and its technical representatives) and the RWQCB meet to develop an alternative strategy to the proposed clean closure. In the latter case, one alternative that should be considered is to continue the closure as proposed, and that groundwater monitoring be continued as a Postclosure activity.

The groundwater beneath the ponds is known to be impacted with RDX/HMX, Perchlorate, VOCs and Nitrate, and a groundwater remediation program has been proposed to mitigate the contaminant plume (V. Madrid et al., 2002). In the event that the surface impoundments are not clean closed (as discussed above), ongoing monitoring of the groundwater in this area in association with the CERCLA remediation program could be performed in lieu of closure as a landfill. If the monitoring indicates that there are groundwater impacts related to the surface impoundments, then the existing groundwater remediation program could be evaluated and augmented, as necessary, to account for the surface impoundment source contribution.

\subsection{Site Re-grading}

Upon removal of the impoundment construction materials, and confirmation that the remaining soils meet the clean closure criteria discussed in Section 4.6.2, the site will be regraded. The existing berms will be excavated and the general fill materials will be utilized to fill in the former impoundment areas in a balanced cut and fill approach (i.e., no materials will be imported for fill). The proposed final grades will result in a relatively gentle, flat surface across the top of the ridge. The graded area will drain to the east-southeast at an approximate grade of $6 \%$ in the upper impoundment area and $4 \%$ in the lower impoundment area. The engineered fill will be placed in a controlled fashion and will meet specifications as outlined in the attached Construction Plans and Construction Specifications (Appendix C and D). Figures 7 and 8 present the proposed final grades for the surface impoundment areas.

\subsection{Hydroseeding}

All disturbed areas of the clean closure site will be re-vegetated with a seed mix developed by LLNL to best match native species. It is anticipated that the re-vegetation will be performed by hydroseeding with an appropriate mixture of seed, fertilizer, tackifier and/or mulch. Straw wattles may be used in local areas to further protect against erosion. The subcontractor shall be responsible for specifying the methodology and equipment for application of the hydroseed, the installation of the wattles, and the appropriate timing to ensure germination of the seed. The methods and equipment shall be approved by LLNL and/or their authorized representative. 


\subsection{CONSTRUCTION SCHEDULE}

LLNL is currently coordinating with the U.S. Fish and Wildlife Service for relevant permits related to protection of potential California Tiger Salamander habitat. The requirements of the permits will determine the actual start date of the clean closure project. For planning purposes, LLNL is assuming that the clean closure project will occur in the summer of 2005 . The replacement tanks will be installed between March 2005 and May 2005 since there are no habitat issues associated with this portion of the project.

Figure 9 shows the proposed construction schedule, assuming clean closure of the impoundments can begin in the summer of 2005. The replacement tanks will be installed between March 2005 and April 2005. Once the tanks have been constructed, process water from the various site operations will be diverted to the tanks, and liquids will be evaporated from the impoundments. After evaporation of the liquids has occurred, the sludge and sand ballast within the impoundments will be sampled and analyzed to ensure they meet criteria for disposal at a Class II landfill (Altamont Landfill).

Following removal and disposal of the sludge, sand ballast, geomembrane, and LCRS sand, samples will then be collected from the clay liner and the underlying soils. The subcontractor shall allow for a six-week period in the construction schedule to allow for sampling and analysis of the clay liner and underlying soils. The analytical results will determine the need for any removal of these materials. Following excavation of any impacted subgrade materials, the site will be re-graded and hydroseeded.

The anticipated duration for the entire project is eight months including the tank installation project, pond evaporation, and the grading of the impoundments. The tank installation project is estimated at approximately 8 weeks from March 2005 to the end of April 2005. The grading portion of the impoundment closure will start in early July and extend to mid to late September 2005. Hydroseeding will be performed in mid October concurrent with the onset of the winter 2005-2006 rainy season. 


\subsection{POSTCLOSURE MONITORING, MAINTENANCE AND LAND USE}

Postclosure land use will be open space. No construction or new facilities are currently anticipated for the former surface impoundment areas; however, LLNL is not precluded from future development or use of the impoundment site.

Maintenance of the clean closure area will be minimal, and will entail visual observation by LLNL staff for evidence of run on, excessive run off, or erosion. If areas of significant erosion are observed, appropriate actions will be implemented to correct the observed conditions.

It is recommended that the surface impoundment groundwater monitoring program be terminated, and the WDR associated with the impoundments rescinded, following successful completion of the clean closure project. If contamination is encountered in native soils underlying the surface impoundments, and the site is not clean closed, then it is recommended that groundwater monitoring activities related to the CERCLA monitoring and remediation project be continued in lieu of closure as a landfill. If the monitoring indicates that there are groundwater impacts related to the surface impoundments, then the existing groundwater remediation program could be evaluated and augmented, as necessary, to account for the surface impoundment source contribution. 


\subsection{REFERENCES}

California Regional Water Quality Control Board, Central Valley Region (CVRWQCB), 1986. The Designated Level Methodology for Waste Classification and Cleanup Level Determination. October 1986, updated June 1989.

California Regional Water Quality Control Board, Central Valley Region (CVRWQCB), 1996. Order No. 96-248, Waste Discharge Requirements for University of California Lawrence Livermore National Laboratory, Experimental Test Site (Site 300) and U.S. Department of Energy Evaporation and Percolation Ponds and Class II Surface Impoundments, Alameda and San Joaquin Counties. 1996.

Daily, B. and Ramirez, A., 1999. EOM Results from the Process Ponds. August 24, 1999.

Emcon Associates, 1990. Letter Report, Liner Repair, HE Process Area, Site 300. March 21, 1990.

Emcon Associates, 1990. Letter Report, Certification Report, HE Process Area, Evaporation Pond HDPE Pipe Boot Installation, Site 300. March 21, 1990.

Lawrence Livermore National Laboratory, Environmental Protection Department, Operations and Regulatory Affairs Division, 2002. LLNL Experimental Test Site 300, Compliance Monitoring Program for Waste Discharge Requirements 96-248, Annual/Fourth Quarter Report 2002. 2002.

Leak Location Services, Inc., 1996. Report for Electrical Leak Location Survey of Site 300 Holding Pond. January 5, 1996.

V. Madrid, L. Ferry, A. Ritcey, J. Valett, M. Verce, 2002. UCRL-AR-147095 Interim Remedial Design for the High Explosives Process Area Operable Unit at Lawrence Livermore National Laboratory Site 300. August 2002 (197 pp - 16.1 MB).

Oregon Climate Service (OCS), 1995. http://www.wrcc.dri.edu/pcpn/ca_north.gif. 1995.

Raber, E. 1983. Chemical and Hydrogeological Evaluation of High-explosive Process Wastewater Discharges at Site 300, Lawrence Livermore National Laboratory, Livermore, California. (UCID19753).

State Water Resources Control Board (SWRCB), 1999. Fact Sheet for Water Quality Order 99-08DWQ, NPDES General Permit for Storm Water Discharge Associated with Construction Activity. 1999.

State Water Resources Control Board (SWRCB), 1999. Order No. 99-08-DWQ, NPDES General Permit CAS000002, Waste Discharge Requirements (WDRs) for Discharges of Storm Water Run-off Associated with Construction Activity. 1999.

Western Regional Climate Center, 2004. Northern California Precipitation Frequency Map. http://www.wrcc.dri.edu/pcpnfreq.html.

State Water Resources Control Board (SWRCB), 1997. California Code of Regulations Title 27 Section 21400, Closure Requirements for Surface Impoundments. July 18, 1997.

State Water Resources Control Board (SWRCB), 1997. California Code of Regulations Title 27 Section 21769, Closure and Postclosure Maintenance Plan Requirements. July 18, 1997. 
TABLES 
TABLE 1

WASTEWATER CHEMISTRY

\begin{tabular}{|c|c|c|c|c|c|}
\hline $\begin{array}{l}\text { Sample Designation } \\
\text { Sample Date }\end{array}$ & $\begin{array}{l}\text { Lower Surface } \\
\text { Impoundment } \\
\text { 13-Apr-95 }\end{array}$ & $\begin{array}{c}\text { Upper Surface } \\
\text { Impoundment } \\
\text { 13-Apr-95 }\end{array}$ & $\begin{array}{c}\text { Upper Surface } \\
\text { Impoundment } \\
\text { 30-Jun-95 }\end{array}$ & $\begin{array}{l}\text { Lower Surface } \\
\text { Impoundment } \\
\text { 17-Nov-03 }\end{array}$ & $\begin{array}{l}\text { Lower Surface } \\
\text { Impoundment } \\
\text { (Duplicate) } \\
\text { 17-Nov-03 }\end{array}$ \\
\hline
\end{tabular}

\section{General Minerals, etc.}

Bicarbonate Alk (as CaCO3)

Calcium

Carbonate Alk (as CaCO3)

Chloride

Fluoride

Magnesium

Nitrate as NO3

Nitrate as NO3

Nitrate/Nitrite

Ortho-phosphate

Perchlorate

Phosphorus (total)

Potassium

Sodium

Specific Conductance

Sulfate

Surfactant (MBAS)

Total Alkalinity (as $\mathrm{CaCO} 3$ )

Total Hardness (as $\mathrm{CaCO} 3$ )

Total dissolved solids (TDS)

Zinc

$\mathrm{pH}$

\begin{tabular}{cl} 
Method & Units \\
\hline 310.1 & $\mathrm{mg} / \mathrm{L}$ \\
260.7 & $\mathrm{mg} / \mathrm{L}$ \\
310.1 & $\mathrm{mg} / \mathrm{L}$ \\
300 & $\mathrm{mg} / \mathrm{L}$ \\
5.8 & $\mathrm{mg} / \mathrm{L}$ \\
200.7 & $\mathrm{mg} / \mathrm{L}$ \\
353 & $\mathrm{mg} / \mathrm{L}$ \\
353.2 & $\mathrm{mg} / \mathrm{L}$ \\
353.2 & $\mathrm{mg} / \mathrm{L}$ \\
365.1 & $\mathrm{mg} / \mathrm{L}$ \\
314 & $\mathrm{mg} / \mathrm{L}$ \\
365.4 & $\mathrm{mg} / \mathrm{L}$ \\
200.7 & $\mathrm{mg} / \mathrm{L}$ \\
200.7 & $\mathrm{mg} / \mathrm{L}$ \\
120.1 & $\mathrm{umhos} / \mathrm{cm}$ \\
300 & $\mathrm{mg} / \mathrm{L}$ \\
425.1 & $\mathrm{mg} / \mathrm{L}$ \\
310.1 & $\mathrm{mg} / \mathrm{L}$ \\
$\mathrm{SM} .234 . \mathrm{B}$ & $\mathrm{mg} / \mathrm{L}$ \\
160.1 & $\mathrm{mg} / \mathrm{L}$ \\
$6010 \mathrm{~B}$ & $\mathrm{mg} / \mathrm{L}$ \\
$\mathrm{pH}$ & $\mathrm{Units}$
\end{tabular}

Metals (EPA Method 6000/7000)

Aluminum
Aluminum
Antimony
Arsenic
Barium
Beryllium
Cadmium
Chromium
Hexavalent Chromium
Cobalt
Copper
Copper

Copper

ns
ns
ns
$n s$
$n s$
$n s$
$n s$
$n s$
$n s$
$n s$
$n s$
$n s$
$n s$
$n s$
$n s$
$n s$
$n s$
$n s$
$n s$
$n s$
$n s$
$n s$

$\begin{array}{cc}\text { ns } & 1400 \\ \text { ns } & 1.7 \\ \text { ns } & 580 \\ \text { ns } & 740 \\ \text { ns } & 2.3 \\ \text { ns } & 0.93 \\ \text { ns } & \text { ns } \\ \text { ns } & \text { ns } \\ \text { ns } & \text { ns } \\ \text { ns } & \text { ns } \\ \text { ns } & \text { ns } \\ \text { ns } & \text { ns } \\ \text { ns } & 65 \\ \text { ns } & 2300 \\ \text { ns } & 7600 \\ \text { ns } & 1300 \\ \text { ns } & <0.5 \\ \text { ns } & 2000 \\ \text { ns } & 8 \\ \text { ns } & 6000 \\ \text { ns } & 0.051 \\ \text { ns } & 9.7\end{array}$

$\begin{array}{cc}870 & 1400 \\ 5.4 & 5.5 \\ 3900 & 5700 \\ 2280 & 3070 \\ 5.8 & 6.8 \\ 1.1 & 2.1 \\ <0.4 & <0.4 \\ <0.1 & <0.1 \\ <0.1 & <0.1 \\ 1.1 & 0.083 \\ <0.004 & 0.004 \\ 2.5 & 2.4 \\ 220 & 220 \\ 4900 & 6700 \\ 19100 & 26500 \\ 2560 & 5040 \\ 0.69 & \mathrm{~ns} \\ 4800 & 7100 \\ 18 & 21 \\ 12800 & 18400 \\ <0.5 & \mathrm{~ns} \\ 10.0 & 9.91\end{array}$

$\begin{array}{ccccc}<0.2 & <0.2 & <0.2 & <0.5 & <0.5 \\ \mathrm{~ns} & \mathrm{~ns} & \mathrm{~ns} & <0.5 & \mathrm{~ns} \\ <0.005 & <0.005 & 0.028 & \mathrm{~ns} & \mathrm{~ns} \\ 0.021 & 0.014 & 0.01 & \mathrm{~ns} & \mathrm{~ns} \\ 0.036 & 0.057 & 0.05 & \mathrm{~ns} & \mathrm{~ns} \\ <0.0005 & <0.0005 & <0.0005 & \mathrm{~ns} & \mathrm{~ns} \\ <0.0005 & <0.0005 & <0.0005 & \mathrm{~ns} & \mathrm{~ns} \\ 0.0019 & 0.0017 & 0.0016 & \mathrm{~ns} & \mathrm{~ns} \\ <0.01 & <0.01 & \mathrm{~ns} & \mathrm{~ns} & \mathrm{~ns} \\ <0.025 & <0.025 & <0.025 & \mathrm{~ns} & \mathrm{~ns} \\ 0.011 & 0.012 & 0.003 & <0.1 & \mathrm{~ns} \\ \mathrm{~ns} & \mathrm{~ns} & \mathrm{~ns} & <0.1 & \mathrm{~ns}\end{array}$


TABLE 1

WASTEWATER CHEMISTRY

\begin{tabular}{|c|c|c|c|c|c|c|}
\hline $\begin{array}{l}\text { Sample Designation } \\
\text { Sample Date }\end{array}$ & & $\begin{array}{c}\text { Lower Surface } \\
\text { Impoundment } \\
\text { 13-Apr-95 }\end{array}$ & $\begin{array}{l}\text { Upper Surface } \\
\text { Impoundment } \\
\text { 13-Apr-95 }\end{array}$ & $\begin{array}{c}\text { Upper Surface } \\
\text { Impoundment } \\
\text { 30-Jun-95 }\end{array}$ & $\begin{array}{c}\text { Lower Surface } \\
\text { Impoundment } \\
\text { 17-Nov-03 }\end{array}$ & $\begin{array}{c}\text { Lower Surface } \\
\text { Impoundment } \\
\text { (Duplicate) } \\
\text { 17-Nov-03 }\end{array}$ \\
\hline Iron & $200.7 \mathrm{mg} / \mathrm{L}$ & ns & ns & $\mathrm{ns}$ & $<0.5$ & ns \\
\hline Lead & $\mathrm{mg} / \mathrm{L}$ & 0.0069 & 0.0069 & $<0.002$ & ns & ns \\
\hline Lithium & 200.7 mg/L & ns & ns & ns & 0.51 & ns \\
\hline Manganese & $\mathrm{mg} / \mathrm{L}$ & 0.051 & $<0.03$ & $<0.03$ & $<0.1$ & ns \\
\hline Manganese & 200.7 mg/L & ns & ns & ns & $<0.1$ & ns \\
\hline Mercury & $7470 \mathrm{mg} / \mathrm{L}$ & $<0.0002$ & $<0.0002$ & $<0.0002$ & ns & ns \\
\hline Molybdenum & $\mathrm{mg} / \mathrm{L}$ & $<0.025$ & $<0.025$ & 0.065 & ns & ns \\
\hline Nickel & $\mathrm{mg} / \mathrm{L}$ & $<0.005$ & $<0.005$ & 0.014 & $<0.5$ & ns \\
\hline Nickel & 200.7 mg/L & ns & ns & ns & $<0.5$ & ns \\
\hline Potassium & $\mathrm{mg} / \mathrm{L}$ & 83 & 61 & 62 & ns & ns \\
\hline Selenium & $\mathrm{mg} / \mathrm{L}$ & $<0.002$ & $<0.002$ & $<0.002$ & ns & ns \\
\hline Silver & $\mathrm{mg} / \mathrm{L}$ & 0.0057 & 0.0019 & 0.0024 & ns & ns \\
\hline Thallium & $\mathrm{mg} / \mathrm{L}$ & $<0.005$ & $<0.005$ & $<0.004$ & ns & ns \\
\hline Vanadium & $\mathrm{mg} / \mathrm{L}$ & $<0.025$ & $<0.025$ & $<0.025$ & ns & ns \\
\hline Zinc & $\mathrm{mg} / \mathrm{L}$ & 0.021 & $<0.02$ & 0.072 & $<0.5$ & ns \\
\hline Zinc & 200.7 mg/L & ns & ns & ns & $<0.5$ & ns \\
\hline Energetic Materials (EPA Method 8330 & $\underline{\text { Units }}$ & & & & & \\
\hline All compounds below method detection limits. & $\mathrm{mg} / \mathrm{kg}$ & & & ns & ns & ns \\
\hline VOCs (EPA Method 624) & $\underline{\text { Units }}$ & & & & & \\
\hline All compounds below method detection limits. & $\mu \mathrm{g} / \mathrm{L}$ & & & ns & ns & ns \\
\hline SVOCs (EPA Method 625) & $\underline{\text { Units }}$ & & & & & \\
\hline All compounds below method detection limits. & $\mu \mathrm{g} / \mathrm{L}$ & & & ns & ns & ns \\
\hline \multicolumn{7}{|c|}{$\begin{array}{l}\mathrm{mg} / \mathrm{L} \text { - milligrams per liter (parts per million) } \\
\mu \mathrm{g} / \mathrm{L} \text { - micrograms per liter (parts per billion) } \\
\mathrm{mg} / \mathrm{kg} \text { - milligrams per kilogram (parts per million) } \\
\text { umhos/com - microsiemens per centimeter } \\
\mathrm{ns} \text { - no sample collected for this analysis } \\
\text { Duplicate samples collected from lower impoundment in November, } 2003 .\end{array}$} \\
\hline
\end{tabular}


TABLE 2

SLUDGE CHEMISTRY

\begin{tabular}{|c|c|c|c|c|}
\hline $\begin{array}{l}\text { Sample Designation } \\
\text { Sample Date }\end{array}$ & Reporting Limit & $\begin{array}{c}\text { Upper Surface } \\
\text { Impoundment } \\
\text { 31-May-02 }\end{array}$ & $\begin{array}{c}\text { Upper Surface } \\
\text { Impoundment } \\
\text { (Duplicate) } \\
\text { 31-May-02 } \\
\end{array}$ & $\begin{array}{r}\text { Lower S } \\
\text { Impounı } \\
\text { 31-Ma } \\
\end{array}$ \\
\hline
\end{tabular}

Soluble Minerals

$\mathrm{pH}$

Perchlorate

Bicarb alkalinity (as $\mathrm{CaCO} 3$ )

Hydroxide alkalinity (as $\mathrm{CaCO} 3$ )

Carbonate alkalinity (as $\mathrm{CaCO}$ )

Total alkalinity (as $\mathrm{CaCO}$ )

Aluminum

Calcium

Chloride

Fluoride

Iron

Magnesium

Nitrate (as NO3)

Nitrite (as N)

Ortho-ohosphate

Potassium

Sodium

Specific conductance

Sulfate

Surfactants

Total dissolved solids (TDS)

Total hardness

Total phosphate

$\begin{array}{lcc}\text { Units } & & \\ \text { units } & 0.1 & 9.7 \\ \mathrm{mg} / \mathrm{L} & 0.004 & \mathrm{nd} \\ \mathrm{mg} / \mathrm{L} & 1 & 190 \\ \mathrm{mg} / \mathrm{L} & 1 & \mathrm{nd} \\ \mathrm{mg} / \mathrm{L} & 1 & 120 \\ \mathrm{mg} / \mathrm{L} & 1 & 310 \\ \mathrm{mg} / \mathrm{L} & 0.2 & 0.8 \\ \mathrm{mg} / \mathrm{L} & 0.5 & 0.8 \\ \mathrm{mg} / \mathrm{L} & 0.5 & 110 \\ \mathrm{mg} / \mathrm{L} & 0.05 & 1.4 \\ \mathrm{mg} / \mathrm{L} & 0.1 & 0.9 \\ \mathrm{mg} / \mathrm{L} & 0.5 & \mathrm{nd} \\ \mathrm{mg} / \mathrm{L} & 1 & 42 \\ \mathrm{mg} / \mathrm{L} & 0.1 & \mathrm{nd} \\ \mathrm{mg} / \mathrm{L} & 0.02 & 0.68 \\ \mathrm{mg} / \mathrm{L} & 1 & 20 \\ \mathrm{mg} / \mathrm{L} & 5 & 260 \\ \mu \mathrm{mh} o s / \mathrm{cm} & 10 & 1400 \\ \mathrm{mg} / \mathrm{L} & 10 & 130 \\ \mathrm{mg} / \mathrm{L} & 0.5 & \mathrm{nd} \\ \mathrm{mg} / \mathrm{L} & 2 & 850 \\ \mathrm{mg} / \mathrm{L} & 1 & 2 \\ \mathrm{mg} / \mathrm{L} & 0.2 & 0.7\end{array}$

\begin{tabular}{|c|c|}
\hline ns & $9 . \mathrm{c}$ \\
\hline ns & 0.01 \\
\hline ns & 16( \\
\hline ns & nd \\
\hline ns & 22( \\
\hline ns & 380 \\
\hline ns & 3.: \\
\hline ns & $1 . \approx$ \\
\hline ns & 11( \\
\hline ns & 1.4 \\
\hline ns & 3.4 \\
\hline ns & $0 . \subseteq$ \\
\hline ns & 51 \\
\hline ns & nd \\
\hline ns & 1.4 \\
\hline ns & 24 \\
\hline ns & 321 \\
\hline ns & 170 \\
\hline ns & 131 \\
\hline ns & $0 . \epsilon$ \\
\hline ns & 100 \\
\hline ns & 7 \\
\hline ns & 1. $\epsilon$ \\
\hline
\end{tabular}


TABLE 2

SLUDGE CHEMISTRY

\begin{tabular}{|c|c|c|c|c|c|}
\hline $\begin{array}{l}\text { Sample Designation } \\
\text { Sample Date }\end{array}$ & & Reporting Limit & $\begin{array}{c}\text { Upper Surface } \\
\text { Impoundment } \\
\text { 31-May-02 }\end{array}$ & $\begin{array}{c}\text { Upper Surface } \\
\text { Impoundment } \\
\text { (Duplicate) } \\
\text { 31-May-02 }\end{array}$ & $\begin{array}{r}\text { Lower S } \\
\text { Impounı } \\
\text { 31-Ma' }\end{array}$ \\
\hline STLC Soluble Metals (EPA Method 6000/7000) & Units & & & & \\
\hline CAM 17 Barium & $\mathrm{mg} / \mathrm{L}$ & 0.6 & $1.7 / 1.7$ & ns & $1 . \xi$ \\
\hline
\end{tabular}

All other compounds below method detection limits.

\section{CAM 17 Total Metals (EPA Method 6000/7000)}

\section{Barium}

Beryllium

Cadmium

Chromium

Cobalt

Copper

Lead

Nickel

Silver

Vanadium

Zinc

All other compounds below method detection limits.

$\underline{\text { TCLP Volatile Organics (EPA Method 0311/8260B) }}$

All compounds below method detection limits.

\section{$\underline{\text { TCLP SemiVolatile Organics (EPA Method 1311/8270B) }}$}

All compounds below method detection limits. $\underline{\text { Units }}$

$\mathrm{mg} / \mathrm{kg}$

$\mathrm{mg} / \mathrm{kg}$

$\mathrm{mg} / \mathrm{kg}$

$\mathrm{mg} / \mathrm{kg}$

$\mathrm{mg} / \mathrm{kg}$

$\mathrm{mg} / \mathrm{kg}$

$\mathrm{mg} / \mathrm{kg}$

$\mathrm{mg} / \mathrm{kg}$

$\mathrm{mg} / \mathrm{kg}$

$\mathrm{mg} / \mathrm{kg}$

$\mathrm{mg} / \mathrm{kg}$

5.0

0.1

0.2

5.0

0.5

4.0

5.0

5.0

0.1

5.0

5.0

35

nd

nd

6.1

2.9

5.1

nd

5.2

0.97

25

22

$\begin{array}{cc}35 & 11 ! \\ \text { nd } & 0.3 \\ \text { nd } & 0.4 \\ 6.1 & 101 \\ 2.7 & 27 \\ 5.7 & 34 \\ \text { nd } & 16 \\ <5.0 & 111 \\ 1.6 & \mathrm{nc} \\ 23 & 11 ! \\ 23 & 7 \varepsilon\end{array}$

1

27

$1 \epsilon$

111

11

$7 \varepsilon$ 
TABLE 2

SLUDGE CHEMISTRY

\begin{tabular}{|c|c|c|c|c|c|}
\hline $\begin{array}{l}\text { Sample Designation } \\
\text { Sample Date }\end{array}$ & & Reporting Limit & $\begin{array}{c}\text { Upper Surface } \\
\text { Impoundment } \\
\text { 31-May-02 }\end{array}$ & $\begin{array}{c}\text { Upper Surface } \\
\text { Impoundment } \\
\text { (Duplicate) } \\
\text { 31-May-02 } \\
\end{array}$ & $\begin{array}{r}\text { Lower S } \\
\text { Impoun } \\
\text { 31-Ma } \\
\end{array}$ \\
\hline \multicolumn{6}{|c|}{ Energetic Materials (EPA Method 8330) } \\
\hline 2-Amino-4,6-dinitrotoluene & $\mathrm{mg} / \mathrm{kg}$ & 0.08 & nd & 0.0366 & 0.03 \\
\hline p-nitrotoluene & $\mathrm{mg} / \mathrm{kg}$ & 0.08 & nd & nd & 0.08 \\
\hline o-nitrotoluene & $\mathrm{mg} / \mathrm{kg}$ & 0.08 & 0.0925 & 0.11 & 0 \\
\hline TATB & $\mathrm{mg} / \mathrm{kg}$ & 0.099 & nd & nd & \\
\hline
\end{tabular}

All other compounds below method detection limits.

mg/L - milligrams per liter (parts per million)

$\mathrm{mg} / \mathrm{kg}$ - milligrams per kilogram (parts per million)

nd - Not detected or detected below background screening level or reporting limit

ns - No sample taken

Duplicate samples collected from upper impoundment in May, 2002. 
TABLE 3

BACKGROUND SOILS CHEMISTRY AND SCREENING LEVELS

\begin{tabular}{|c|c|c|c|c|}
\hline & & $\begin{array}{c}\text { Clay Liner } \\
\text { Background } \\
\text { Sampling Data }\end{array}$ & $\begin{array}{c}\text { LLNL } \\
\text { Background } \\
\text { Soils Data }\end{array}$ & $\begin{array}{c}\text { PRGs for Soil } \\
\text { Screening } \\
\text { Levels }\end{array}$ \\
\hline Explosives (EPA 8330) & Units & & & \\
\hline HMX & $\overline{\mathrm{mg} / \mathrm{kg}}$ & tbd & na & na \\
\hline RDX & $\mathrm{mg} / \mathrm{kg}$ & tbd & na & na \\
\hline Inorganics & $\underline{\text { Units }}$ & & & \\
\hline TDS & $\mathrm{mg} / \mathrm{kg}$ & tbd & na & na \\
\hline Total Metals (EPA 6000/7000) & $\underline{\text { Units }}$ & & & \\
\hline Chromium (total) & $\overline{\mathrm{mg} / \mathrm{kg}}$ & tbd & 45.6 & 38 \\
\hline Nickel & $\mathrm{mg} / \mathrm{kg}$ & tbd & 66 & 130 \\
\hline
\end{tabular}

Clay Liner Background Sampling Data to be determined (tbd) by background sampling and anaylsis of liner materials prior to impoundment closure

LLNL Background Soils Data from internal LLNL investigations (Pers. Comm., R. Brown, 2004)

PRGs - Preliminary Remediation Goals issued by USEPA Region 9, 2002. Values for Total Metals based

on Soil Screening Levels "Migration to Groundwater" and Dilution Attenuation Factor (DAF) of 20.

$\mathrm{mg} / \mathrm{kg}$ - milligrams per kilogram (parts per million)

na - not appblicable 
FIGURES 


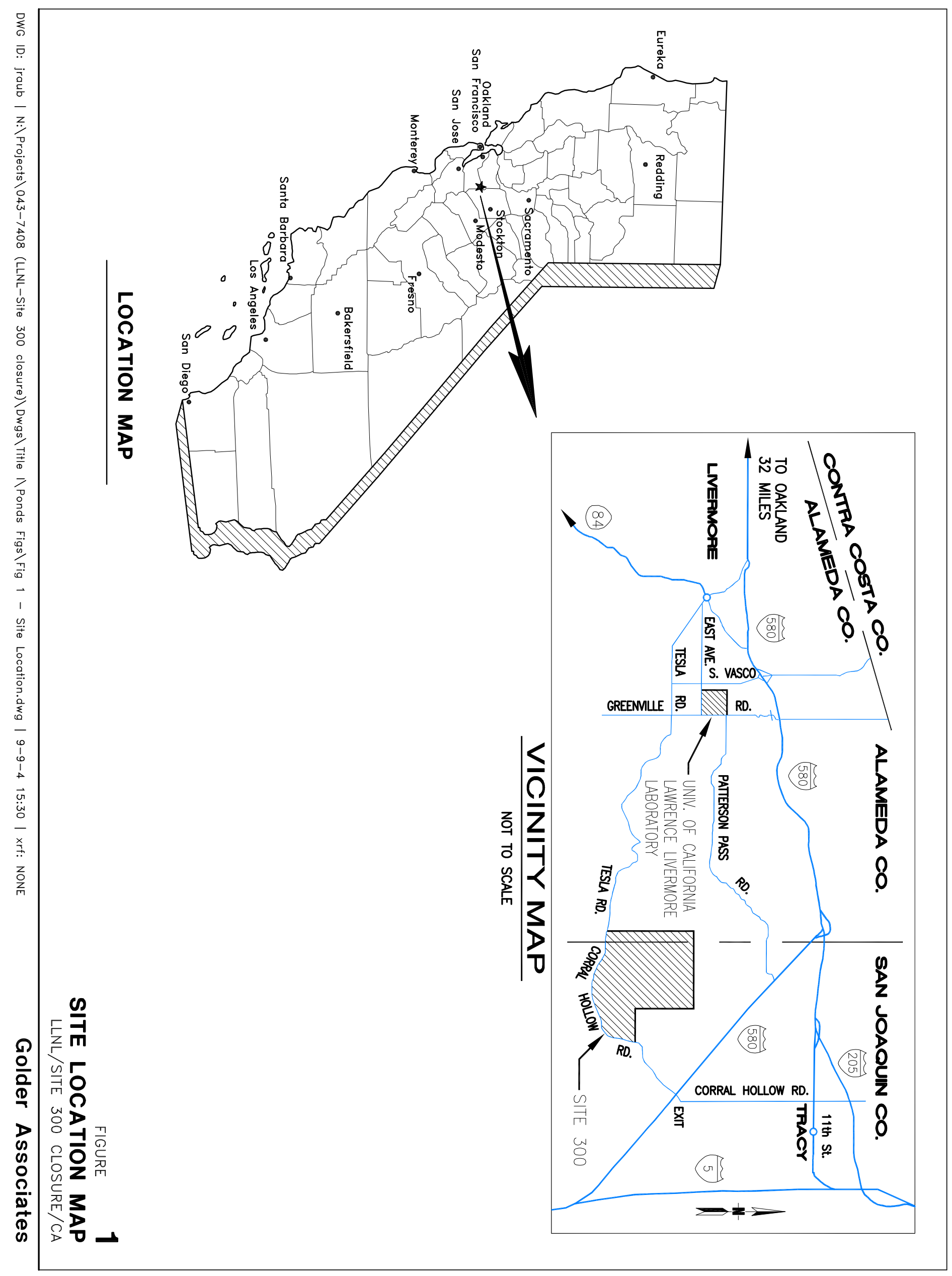




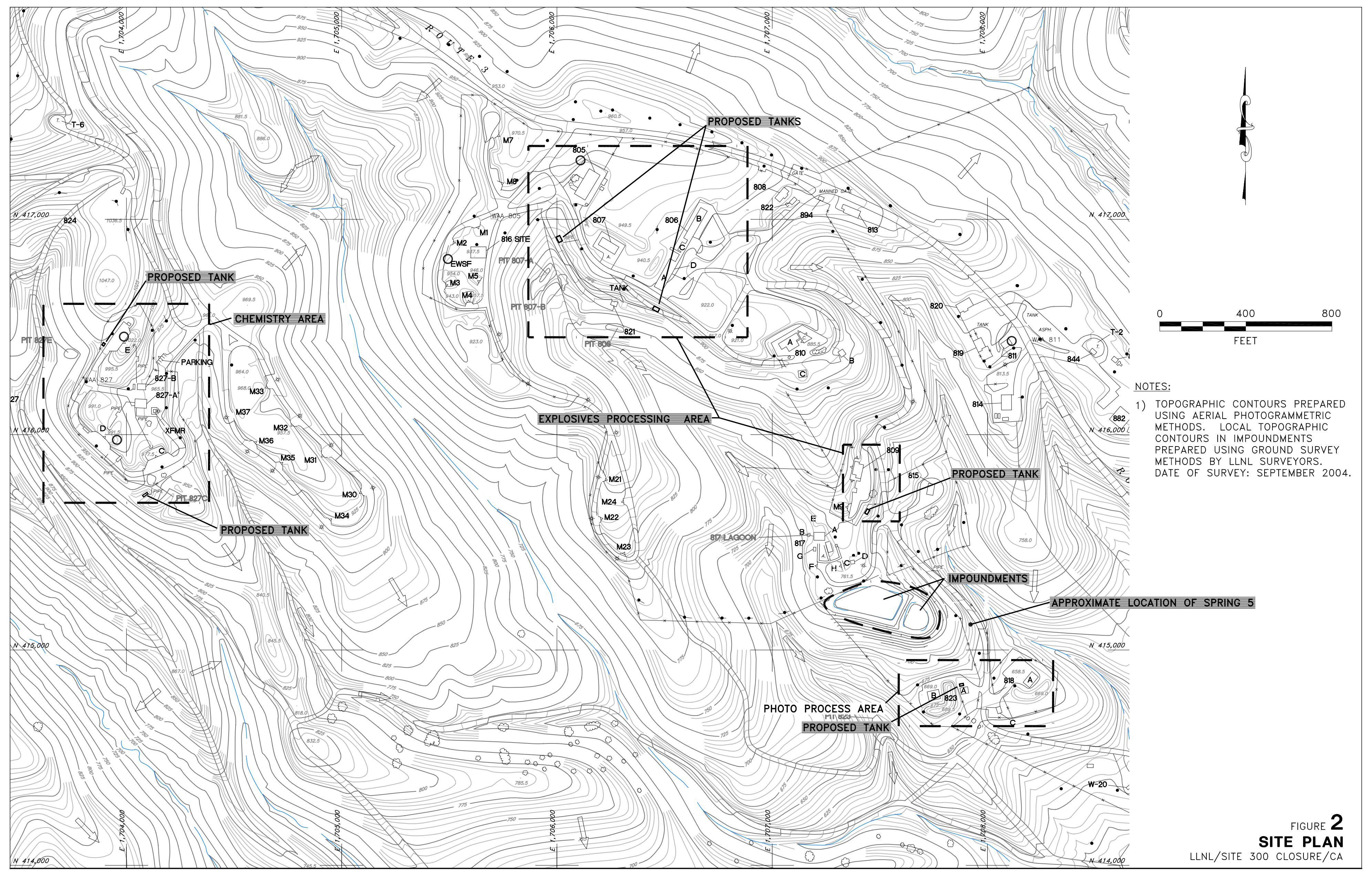

DWG ID: jraub | N: Projects $043-7408$ (LLNL-Site 300 closure) \Closure Plan\Closure plan Final 2-03-05) Figures\Fig 2 - Site Plan.dwg | 2-23-5 9:33 | xr:: PSZ2004-0300-00020_00070 


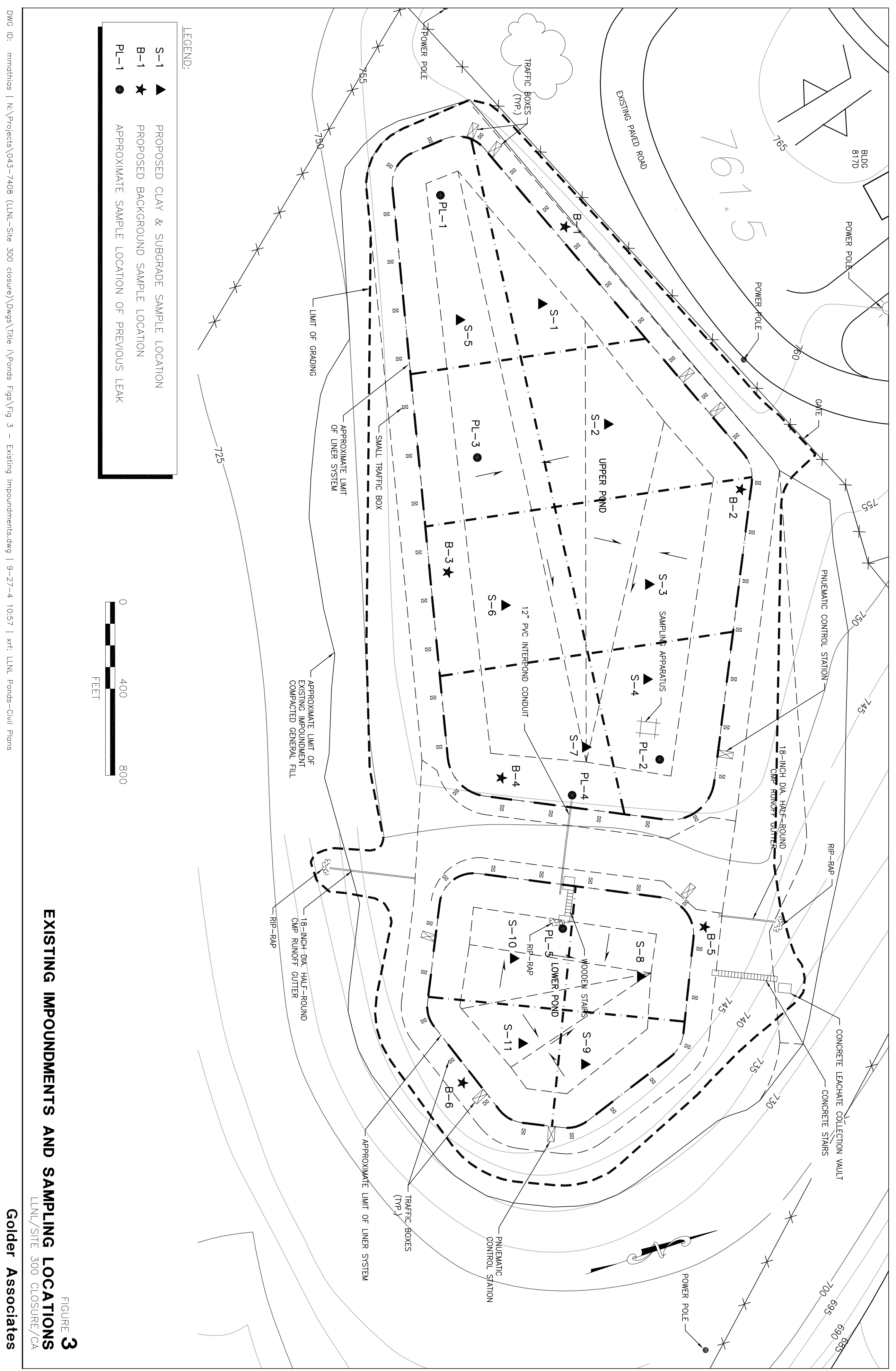




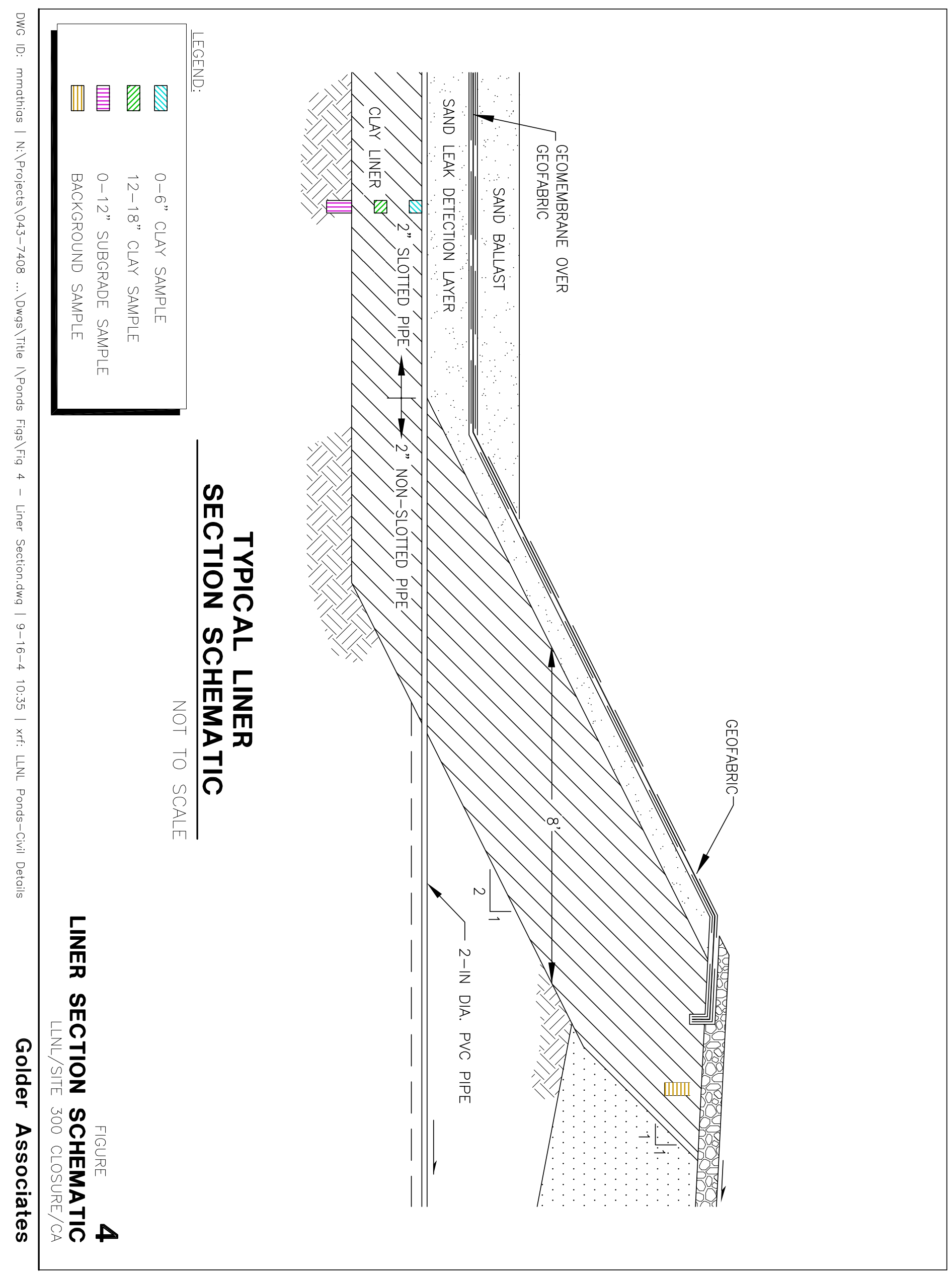




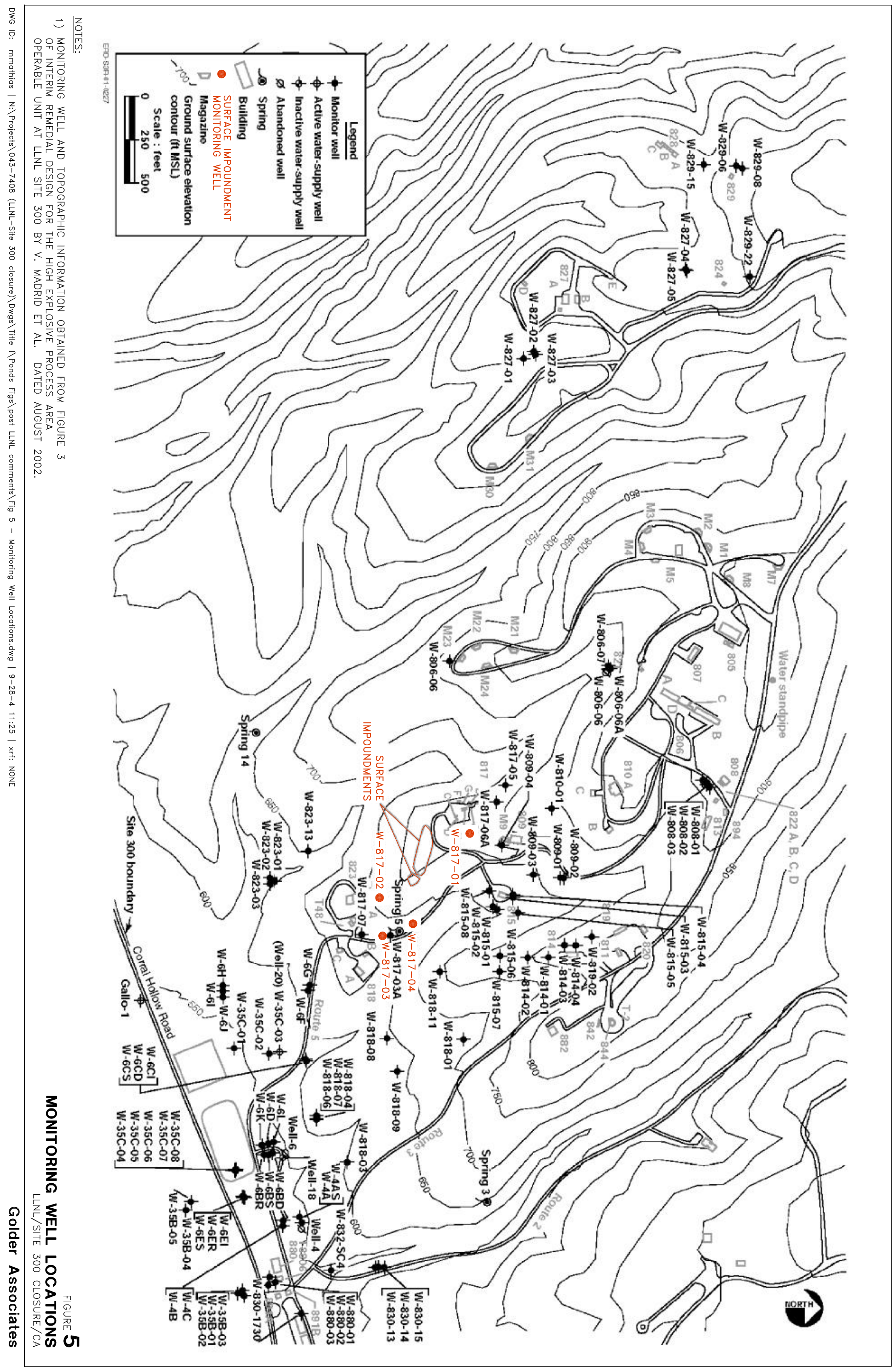




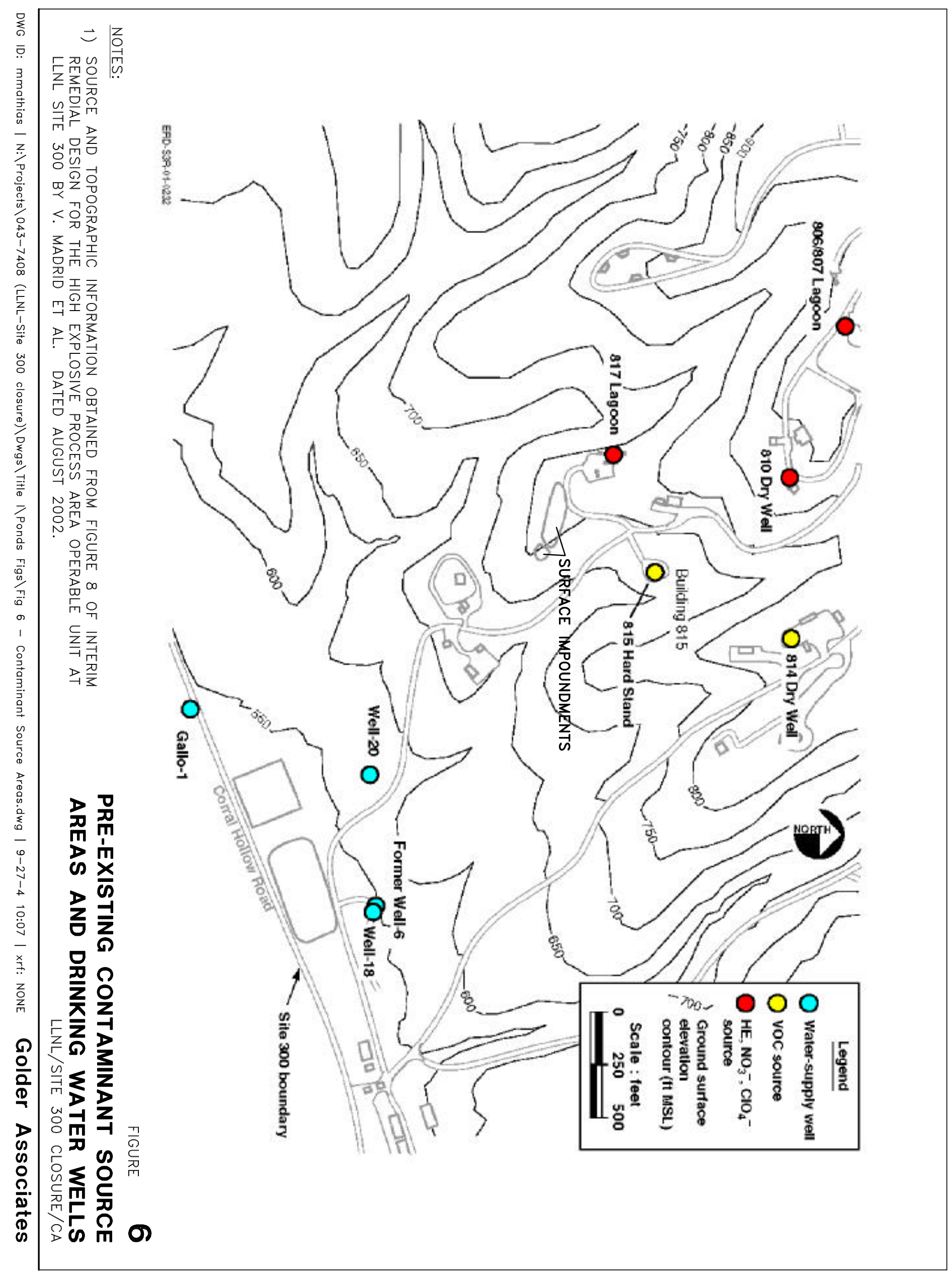




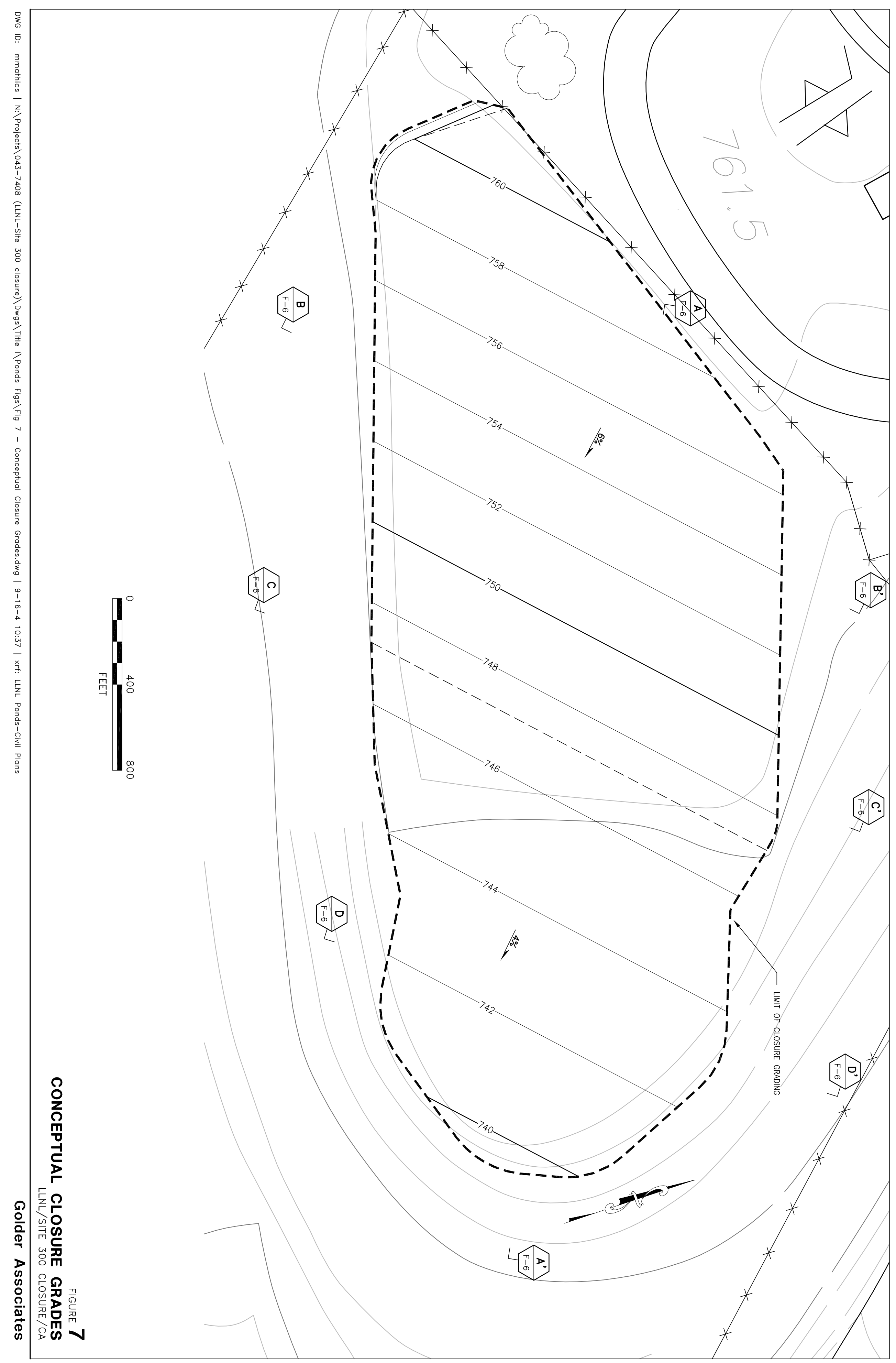




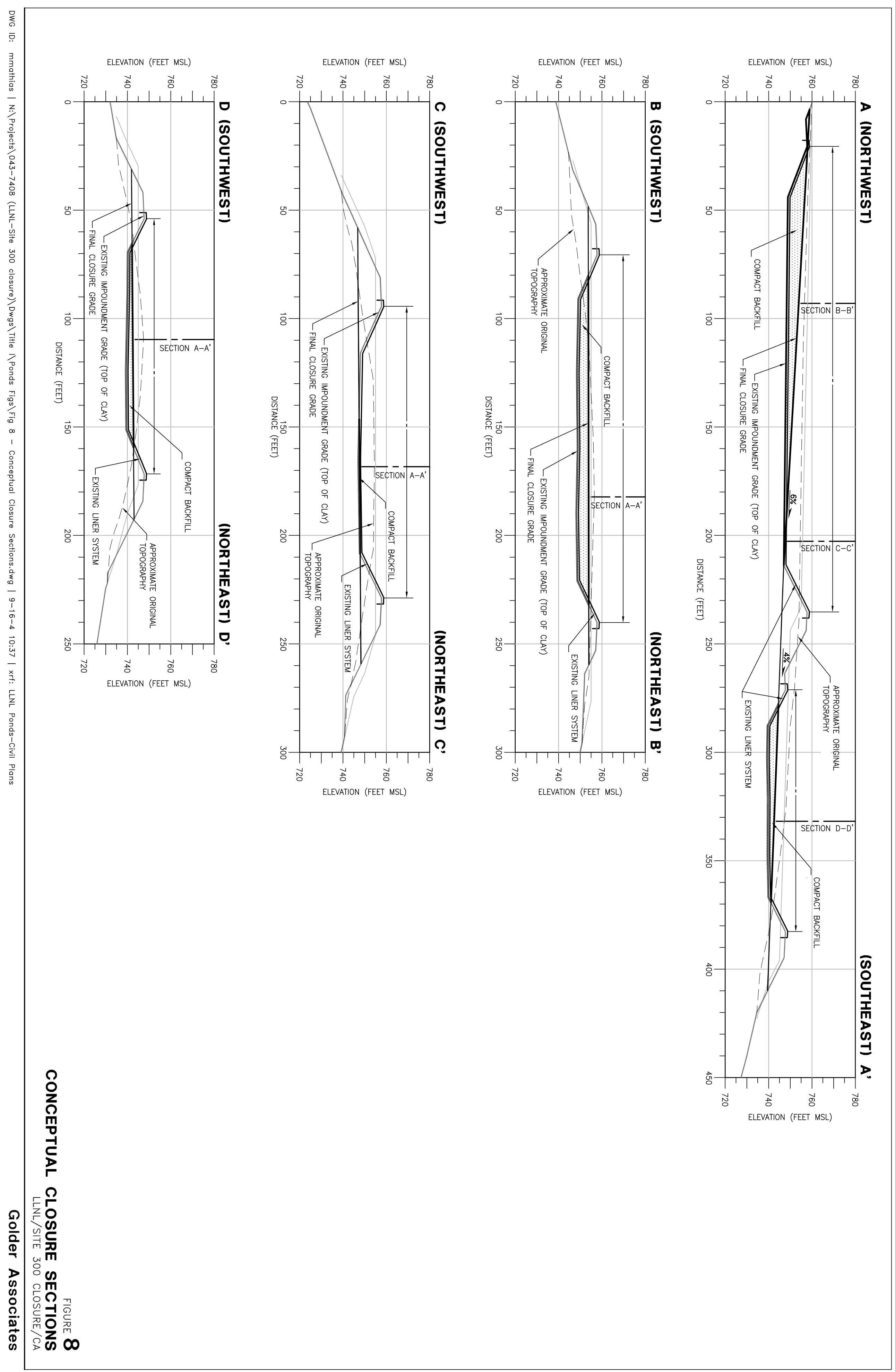




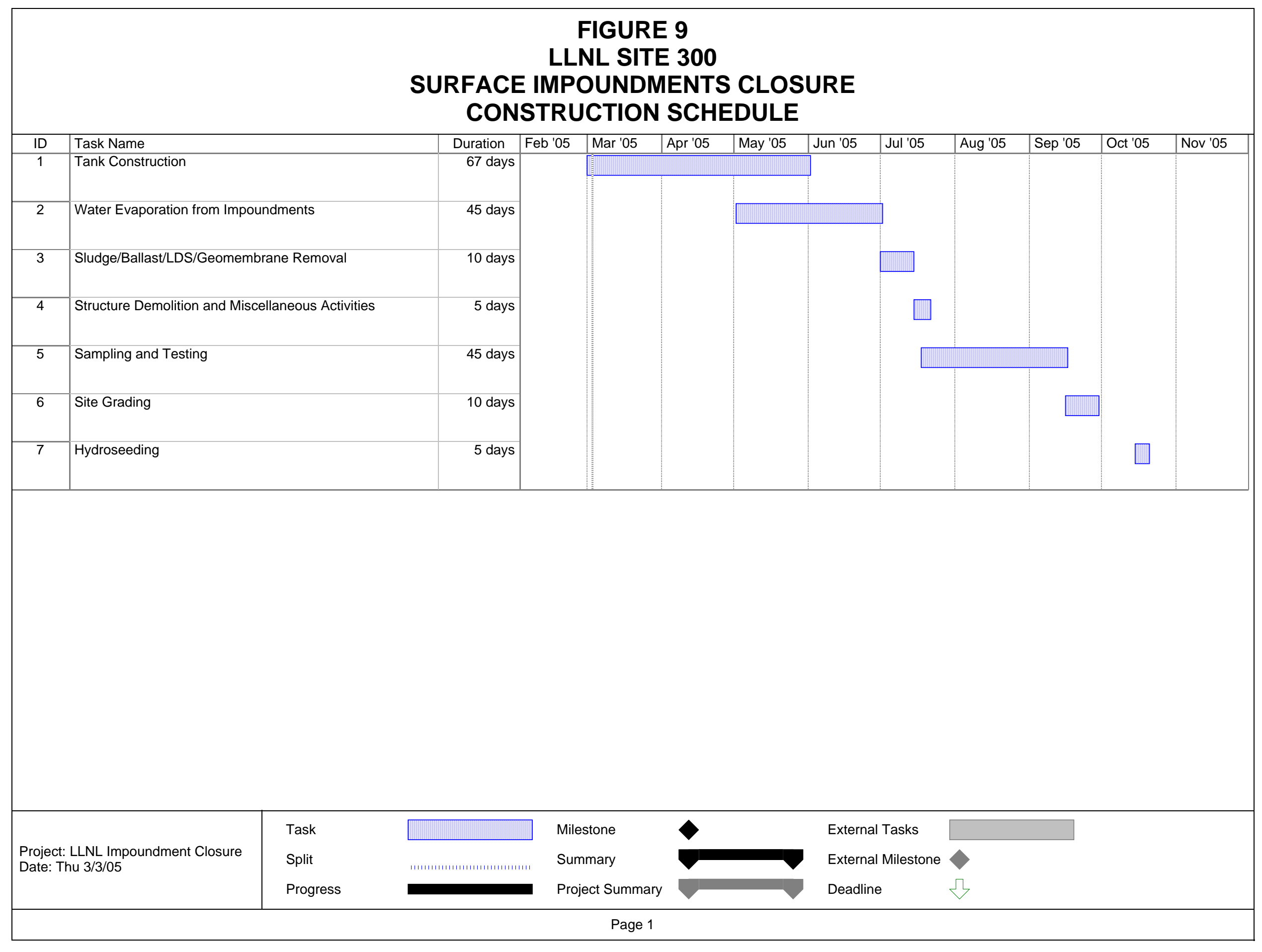




\section{APPENDIX A}

\section{DISCHARGE WASTEWATER CHEMISTRY, SPRING CHEMISTRY,}

AND CONSTITUENTS OF CONCERN 
Appendix A

Historical Analytical Results - Spring 5

Site 300 LLNL

\begin{tabular}{|c|c|c|c|}
\hline & \multicolumn{3}{|c|}{ SIte 3UU LLNL } \\
\hline & & & \\
\hline & & Sample & \\
\hline Parameter & Well & date & Result \\
\hline \multicolumn{4}{|l|}{ General } \\
\hline \multirow[t]{4}{*}{$\mathrm{pH}$ (unitless) } & SPRING5 & 13-Oct-93 & 8.20 \\
\hline & SPRING5 & 9-May-94 & $8.30 / 8.20$ \\
\hline & SPRING5 & 29-Nov-95 & 7.10 \\
\hline & SPRING5 & 25-Jun-96 & $8.60 / 7.80$ \\
\hline \multicolumn{4}{|l|}{ Halocarbons $(\mu \mathrm{g} / \mathrm{L})$} \\
\hline \multirow[t]{4}{*}{ 1,1,1-Trichloroethane } & SPRING5 & $13-$ Oct-93 & $<0.5$ \\
\hline & SPRING5 & 9-May-94 & $<0.5 /<0.5$ \\
\hline & SPRING5 & 29-Nov-95 & $<0.5$ \\
\hline & SPRING5 & 25-Jun-96 & $<0.5 /<1.0$ \\
\hline \multirow[t]{4}{*}{ Bromoform } & SPRING5 & $13-$ Oct-93 & $<0.5$ \\
\hline & SPRING5 & 9-May-94 & $<0.5 /<0.5$ \\
\hline & SPRING5 & 29-Nov-95 & $<0.5$ \\
\hline & SPRING5 & 25-Jun-96 & $<0.5 /<1.0$ \\
\hline \multirow[t]{4}{*}{ 1,2-Dichloroethane } & SPRING5 & 13-Oct-93 & $<0.5$ \\
\hline & SPRING5 & 9-May-94 & $<0.5 /<0.5$ \\
\hline & SPRING5 & 29-Nov-95 & $<0.5$ \\
\hline & SPRING5 & 25-Jun-96 & $<0.5 /<1.0$ \\
\hline \multirow[t]{4}{*}{ Freon 113} & SPRING5 & 13-Oct-93 & $<0.5$ \\
\hline & SPRING5 & 9-May-94 & $<0.5 /<0.5$ \\
\hline & SPRING5 & 29-Nov-95 & $<0.5$ \\
\hline & SPRING5 & 25-Jun-96 & $<0.5 /<1.0$ \\
\hline \multirow[t]{4}{*}{ Methylene chloride } & SPRING5 & 13-Oct-93 & $<0.5$ \\
\hline & SPRING5 & 9-May-94 & $<0.5 /<0.5$ \\
\hline & SPRING5 & 29-Nov-95 & $<0.5$ \\
\hline & SPRING5 & 25-Jun-96 & $<0.5 /<2.0$ \\
\hline \multirow[t]{4}{*}{ Tetrachloroethene } & SPRING5 & 13-Oct-93 & $<0.5$ \\
\hline & SPRING5 & 9-May-94 & $<0.5 /<0.5$ \\
\hline & SPRING5 & 29-Nov-95 & $<0.5$ \\
\hline & SPRING5 & 25-Jun-96 & $<0.5 /<1.0$ \\
\hline \multirow[t]{4}{*}{ Chlorobenzene } & SPRING5 & 13-Oct-93 & $<0.5$ \\
\hline & SPRING5 & 9-May-94 & $<0.5 /<0.5$ \\
\hline & SPRING5 & 29-Nov-95 & $<0.5$ \\
\hline & SPRING5 & 25-Jun-96 & $<0.5 /<1.0$ \\
\hline \multicolumn{4}{|l|}{ Hydrocarbons $(\mu \mathrm{g} / \mathrm{L})$} \\
\hline \multirow[t]{4}{*}{ Toluene } & SPRING5 & $13-$ Oct-93 & NS \\
\hline & SPRING5 & 9-May-94 & NS \\
\hline & SPRING5 & 29-Nov-95 & NS \\
\hline & SPRING5 & 25-Jun-96 & NS \\
\hline \multirow[t]{4}{*}{ Naphthalene } & SPRING5 & $13-$ Oct-93 & NS \\
\hline & SPRING5 & 9-May-94 & NS \\
\hline & SPRING5 & 29-Nov-95 & NS \\
\hline & SPRING5 & 25-Jun-96 & NS \\
\hline \multicolumn{4}{|c|}{ Photographic Chemicals ( $\mu \mathrm{g} / \mathrm{L}$ ) } \\
\hline \multirow[t]{4}{*}{ meta - and para-Cresol } & SPRING5 & $13-0 c t-93$ & NS \\
\hline & SPRING5 & 9-May-94 & NS \\
\hline & SPRING5 & 29-Nov-95 & NS \\
\hline & SPRING5 & 25-Jun-96 & NS \\
\hline
\end{tabular}


Appendix A

Historical Analytical Results - Spring 5

Site 300 LLNL

\begin{tabular}{|c|c|c|c|}
\hline & & Sample & \\
\hline Parameter & Well & date & Result \\
\hline \multirow{4}{*}{ Benzyl acohol } & SPRING5 & 13-Oct-93 & NS \\
\hline & SPRING5 & 9-May-94 & NS \\
\hline & SPRING5 & 29-Nov-95 & NS \\
\hline & SPRING5 & 25-Jun-96 & NS \\
\hline \multicolumn{4}{|c|}{ Volatile/semivolatile organic compounds ( $\mu \mathrm{g} / \mathrm{L})$} \\
\hline \multirow[t]{4}{*}{ Acetone } & SPRING5 & $13-$ Oct-93 & NS \\
\hline & SPRING5 & 9-May-94 & NS \\
\hline & SPRING5 & 29-Nov-95 & NS \\
\hline & SPRING5 & 25-Jun-96 & NS \\
\hline 2-Butanone & SPRING5 & 13-Oct-93 & NS \\
\hline \multirow[t]{3}{*}{ (methyl ethyl ketone) } & SPRING5 & 9-May-94 & NS \\
\hline & SPRING5 & 29-Nov-95 & NS \\
\hline & SPRING5 & 25-Jun-96 & NS \\
\hline \multirow[t]{4}{*}{ Dimethyl sulfoxide (DMSO) } & SPRING5 & $13-$ Oct-93 & NS \\
\hline & SPRING5 & 9-May-94 & NS \\
\hline & SPRING5 & $29-$ Nov-95 & NS \\
\hline & SPRING5 & 25-Jun-96 & NS \\
\hline \multirow[t]{4}{*}{ Ethyl alcohol (ethanol) } & SPRING5 & 13-Oct-93 & NS \\
\hline & SPRING5 & 9-May-94 & NS \\
\hline & SPRING5 & 29-Nov-95 & NS \\
\hline & SPRING5 & 25-Jun-96 & NS \\
\hline \multirow[t]{4}{*}{ Methyl isobutyl ketone } & SPRING5 & $13-$ Oct-93 & NS \\
\hline & SPRING5 & 9-May-94 & NS \\
\hline & SPRING5 & 29-Nov-95 & NS \\
\hline & SPRING5 & 25-Jun-96 & NS \\
\hline \multicolumn{4}{|c|}{ Additives to energetic compounds ( $\mu \mathrm{g} / \mathrm{L}$ ) } \\
\hline \multirow[t]{4}{*}{ Bis(2-ethylhexyl)phthalate } & SPRING5 & $13-0 c t-93$ & NS \\
\hline & SPRING5 & 9-May-94 & NS \\
\hline & SPRING5 & 29-Nov-95 & NS \\
\hline & SPRING5 & 25-Jun-96 & NS \\
\hline \multicolumn{4}{|l|}{ Unreactive polymers ( $\mu \mathrm{g} / \mathrm{L}$ ) } \\
\hline \multirow[t]{4}{*}{ Styrene } & SPRING5 & 13-Oct-93 & NS \\
\hline & SPRING5 & 9-May-94 & NS \\
\hline & SPRING5 & 29-Nov-95 & NS \\
\hline & SPRING5 & 25-Jun-96 & NS \\
\hline \multirow[t]{4}{*}{ Vinyl chloride } & SPRING5 & $13-$ Oct-93 & $<0.5$ \\
\hline & SPRING5 & 9-May-94 & $<0.5 /<0.5$ \\
\hline & SPRING5 & 29-Nov-95 & $<0.5$ \\
\hline & SPRING5 & 25-Jun-96 & $<0.5 /<1.0$ \\
\hline \multicolumn{4}{|l|}{ Metals (mg/L) } \\
\hline \multirow[t]{4}{*}{ Aluminum } & SPRING5 & 13-Oct-93 & $<0.2$ \\
\hline & SPRING5 & 9-May-94 & $<0.2$ \\
\hline & SPRING5 & 29-Nov-95 & $<0.2$ \\
\hline & SPRING5 & 25-Jun-96 & $<0.2 /<0.2$ \\
\hline \multirow[t]{4}{*}{ Arsenic } & SPRING5 & 13-Oct-93 & $<0.002$ \\
\hline & SPRING5 & 9-May-94 & $<0.002 /<0.006$ \\
\hline & SPRING5 & 29-Nov-95 & 0.0035 \\
\hline & SPRING5 & 25-Jun-96 & $<0.002 / 0.0025$ \\
\hline \multirow[t]{2}{*}{ Barium } & SPRING5 & 13-Oct-93 & $<0.05$ \\
\hline & SPRING5 & 9-May-94 & $<0.025 / 0.015$ \\
\hline
\end{tabular}


Appendix A

Historical Analytical Results - Spring 5

Site 300 LLNL

\begin{tabular}{|c|c|c|c|}
\hline & & Sample & \\
\hline \multirow[t]{3}{*}{ Parameter } & Well & date & Result \\
\hline & SPRING5 & 29-Nov-95 & $<0.025$ \\
\hline & SPRING5 & 25-Jun-96 & $<0.025 /<0.025$ \\
\hline \multirow[t]{4}{*}{ Cadmium } & SPRING5 & 13-Oct-93 & $<0.001$ \\
\hline & SPRING5 & 9-May-94 & $<0.0005 /<0.0005$ \\
\hline & SPRING5 & 29-Nov-95 & $<0.0005$ \\
\hline & SPRING5 & 25-Jun-96 & $<0.0005 / 0.0017$ \\
\hline \multirow[t]{4}{*}{ Chromium } & SPRING5 & $13-$ Oct-93 & $<0.01$ \\
\hline & SPRING5 & 9-May-94 & $<0.01 /<0.01$ \\
\hline & SPRING5 & 29-Nov-95 & $<0.01$ \\
\hline & SPRING5 & 25-Jun-96 & $<0.001 /<0.001$ \\
\hline \multirow[t]{4}{*}{ Cobalt } & SPRING5 & 13-Oct-93 & NS \\
\hline & SPRING5 & 9-May-94 & NS \\
\hline & SPRING5 & 29-Nov-95 & NS \\
\hline & SPRING5 & 25-Jun-96 & NS \\
\hline \multirow[t]{4}{*}{ Copper } & SPRING5 & 13-Oct-93 & $<0.05$ \\
\hline & SPRING5 & 9-May-94 & $<0.05 /<0.01$ \\
\hline & SPRING5 & 29-Nov-95 & $<0.05$ \\
\hline & SPRING5 & 25-Jun-96 & $<0.05$ \\
\hline \multirow[t]{4}{*}{ Lead } & SPRING5 & 13-Oct-93 & $<0.005$ \\
\hline & SPRING5 & 9-May-94 & $<0.005 /<0.002$ \\
\hline & SPRING5 & 29-Nov-95 & $<0.002$ \\
\hline & SPRING5 & 25-Jun-96 & $<0.005 /<0.002$ \\
\hline \multirow[t]{4}{*}{ Manganese } & SPRING5 & 13-Oct-93 & $<0.03$ \\
\hline & SPRING5 & 9-May-94 & $<0.03 /<0.005$ \\
\hline & SPRING5 & 29-Nov-95 & $<0.03$ \\
\hline & SPRING5 & 25-Jun-96 & $<0.03 /<0.03$ \\
\hline \multirow[t]{4}{*}{ Molybdenum } & SPRING5 & $13-O c t-93$ & NS \\
\hline & SPRING5 & 9-May-94 & NS \\
\hline & SPRING5 & 29-Nov-95 & NS \\
\hline & SPRING5 & 25-Jun-96 & NS \\
\hline \multirow[t]{4}{*}{ Nickel } & SPRING5 & $13-$ Oct-93 & $<0.1$ \\
\hline & SPRING5 & 9-May-94 & $<0.1$ \\
\hline & SPRING5 & 29-Nov-95 & $<0.1$ \\
\hline & SPRING5 & 25-Jun-96 & $<0.1 /<0.1$ \\
\hline \multirow[t]{4}{*}{ Potassium } & SPRING5 & 13-Oct-93 & 3.1 \\
\hline & SPRING5 & 9-May-94 & $2.9 / 2.9$ \\
\hline & SPRING5 & 29-Nov-95 & 2.8 \\
\hline & SPRING5 & 25-Jun-96 & $2.6 / 2.5$ \\
\hline \multirow[t]{4}{*}{ Silver } & SPRING5 & 13-Oct-93 & $<0.001$ \\
\hline & SPRING5 & 9-May-94 & $<0.001 /<0.001$ \\
\hline & SPRING5 & 29-Nov-95 & $<0.001$ \\
\hline & SPRING5 & 25-Jun-96 & $<0.001 /<0.001$ \\
\hline \multirow[t]{4}{*}{ Zinc } & SPRING5 & 13-Oct-93 & $<0.05$ \\
\hline & SPRING5 & 9-May-94 & $<0.02$ \\
\hline & SPRING5 & 29-Nov-95 & $<0.05$ \\
\hline & SPRING5 & 25-Jun-96 & $<0.05$ \\
\hline \multicolumn{4}{|l|}{ Salts (mg/L) } \\
\hline \multirow[t]{3}{*}{ Ammonia nitrogen (as $N$ ) } & SPRING5 & $13-$ Oct-93 & NS \\
\hline & SPRING5 & 9-May-94 & NS \\
\hline & SPRING5 & 29-Nov-95 & NS \\
\hline
\end{tabular}


Appendix A

Historical Analytical Results - Spring 5

Site 300 LLNL

\begin{tabular}{|c|c|c|c|}
\hline & & Sample & \\
\hline \multirow[t]{2}{*}{ Parameter } & Well & date & Result \\
\hline & SPRING5 & 25-Jun-96 & $<0.02$ \\
\hline Bicarbonate alkalinity & SPRING5 & 13-Oct-93 & 360 \\
\hline \multirow[t]{3}{*}{ (as CaCO3) } & SPRING5 & 9-May-94 & 280 \\
\hline & SPRING5 & 29-Nov-95 & 300 \\
\hline & SPRING5 & 25-Jun-96 & 250 \\
\hline \multirow[t]{4}{*}{ Bromide } & SPRING5 & 13-Oct-93 & NS \\
\hline & SPRING5 & 9-May-94 & NS \\
\hline & SPRING5 & 29-Nov-95 & NS \\
\hline & SPRING5 & 25-Jun-96 & NS \\
\hline \multirow[t]{4}{*}{ Chloride } & SPRING5 & 13-Oct-93 & 830 \\
\hline & SPRING5 & 9-May-94 & $490 / 540$ \\
\hline & SPRING5 & 29-Nov-95 & 670 \\
\hline & SPRING5 & 25-Jun-96 & $460 / 170$ \\
\hline \multirow[t]{4}{*}{ Nitrate (as NO3) } & SPRING5 & 13-Oct-93 & 44.3 \\
\hline & SPRING5 & 9-May-94 & $137.3 / 487.3$ \\
\hline & SPRING5 & 29-Nov-95 & 99 \\
\hline & SPRING5 & 25-Jun-96 & $94 / 102$ \\
\hline \multirow[t]{4}{*}{ Ortho-phosphate } & SPRING5 & 13-Oct-93 & NS \\
\hline & SPRING5 & 9-May-94 & NS \\
\hline & SPRING5 & 29-Nov-95 & NS \\
\hline & SPRING5 & 25-Jun-96 & $0.36 / 0.11$ \\
\hline \multirow[t]{4}{*}{ Perchlorate } & SPRING5 & $13-$ Oct-93 & NS \\
\hline & SPRING5 & 9-May-94 & NS \\
\hline & SPRING5 & 29-Nov-95 & NS \\
\hline & SPRING5 & 25-Jun-96 & NS \\
\hline \multirow[t]{4}{*}{ Sulfate } & SPRING5 & 13-Oct-93 & 29 \\
\hline & SPRING5 & 9-May-94 & $57 / 33$ \\
\hline & SPRING5 & 29-Nov-95 & 33 \\
\hline & SPRING5 & 25-Jun-96 & $36.6 / 51$ \\
\hline \multicolumn{4}{|l|}{ Energetic materials $(\mu \mathrm{g} / \mathrm{L})$} \\
\hline \multirow[t]{4}{*}{$\mathrm{HMX}$} & SPRING5 & 13-Oct-93 & $<20$ \\
\hline & SPRING5 & 9-May-94 & $<10$ \\
\hline & SPRING5 & 29-Nov-95 & $<5$ \\
\hline & SPRING5 & 25-Jun-96 & $<5$ \\
\hline \multirow[t]{4}{*}{ RDX } & SPRING5 & $13-$ Oct-93 & $<30$ \\
\hline & SPRING5 & 9-May-94 & $<10$ \\
\hline & SPRING5 & 29-Nov-95 & $<5$ \\
\hline & SPRING5 & 25-Jun-96 & $<5$ \\
\hline \multirow[t]{4}{*}{ TNT } & SPRING5 & $13-$ Oct-93 & $<30$ \\
\hline & SPRING5 & 9-May-94 & $<5$ \\
\hline & SPRING5 & 29-Nov-95 & NS \\
\hline & SPRING5 & 25-Jun-96 & NS \\
\hline \multicolumn{4}{|l|}{${ }^{a} \mathrm{MDL}=$ Method detection limit. } \\
\hline \multicolumn{4}{|l|}{ NS = Not sampled \& analyzed. } \\
\hline \multicolumn{4}{|c|}{ Note: if more than one sample result occurs in a row, duplicate sample results are represented } \\
\hline Data provided by R. Brown, LLNL. & & & \\
\hline
\end{tabular}


APPENDIX B

SAMPLING AND ANALYSIS PLAN 


\title{
Golder Associates
}

\section{SAMPLING AND ANALYSIS PLAN SITE 300 SURFACE IMPOUNDMENTS CLOSURE LAWRENCE LIVERMORE NATIONAL LABORATORY LIVERMORE, CALIFORNIA UCRL-SR-206943}

\author{
Submitted to: \\ Lawrence Livermore National Laboratory \\ 7000 East Avenue \\ L-654 P.O. Box 808 \\ Livermore, CA 94551
}

Submitted by:

Golder Associates Inc.

1009 Enterprise Way

Suite 350

Roseville, California 95678

Distribution:

(2) Copies LLNL

(1) Copy Golder Associates Inc. 


\title{
is Golder
}

\author{
SAMPLING AND ANALYSIS PLAN \\ SITE 300 SURFACE IMPOUNDMENTS CLOSURE \\ LAWRENCE LIVERMORE NATIONAL LABORATORY \\ LIVERMORE, CALIFORNIA \\ UCRL-SR-206943
}

\author{
Submitted to: \\ Lawrence Livermore National Laboratory \\ 7000 East Avenue \\ L-654 P.O. Box 808 \\ Livermore, CA 94551
}

Submitted by:

Golder Associates Inc.

1009 Enterprise Way

Suite 350

Roseville, California 95678

Golder Associates Inc.
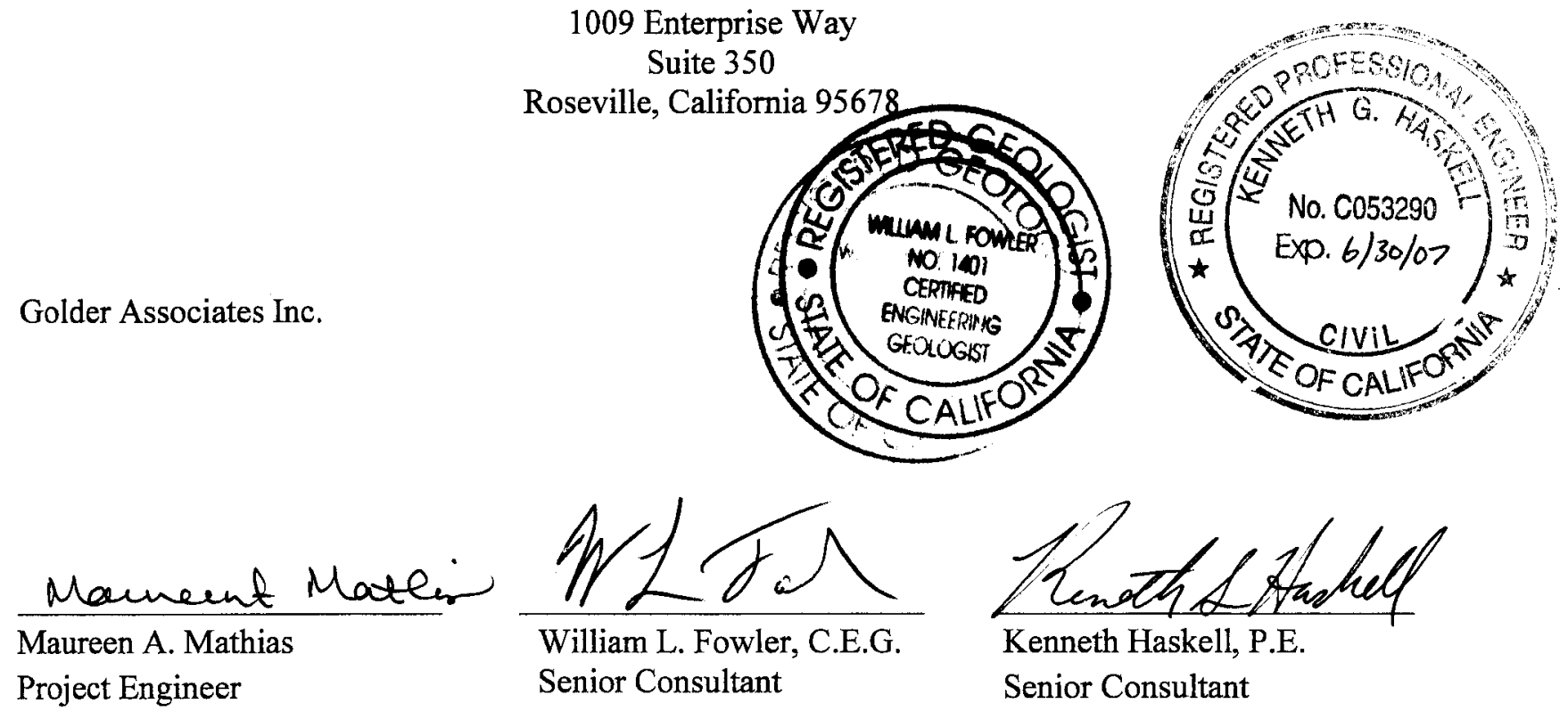


\section{SAMPLING AND ANALYSIS PLAN SITE 300 SURFACE IMPOUNDMENTS CLOSURE}

\section{TABLE OF CONTENTS}

$\underline{\text { Section }}$

$\underline{\text { Page }}$

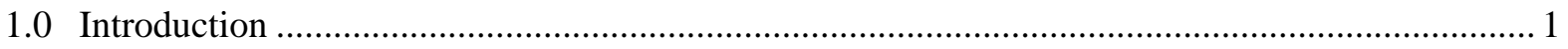

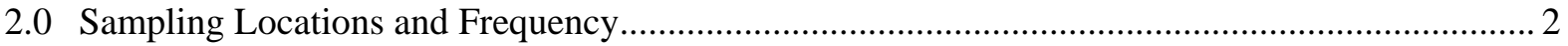

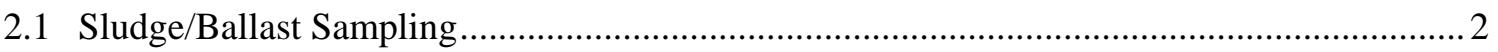

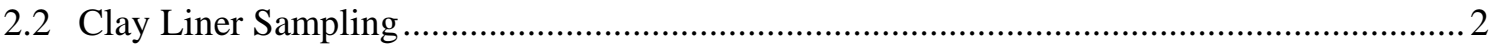

2.3 Subsurface Soils Sampling ….......................................................................................

3.0 Sample Collection and Handling Procedures ......................................................................... 4

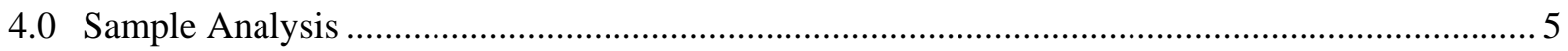

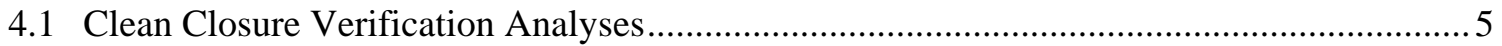

4.2 Clean Closure Contingency Sampling and Analysis ......................................................... 5

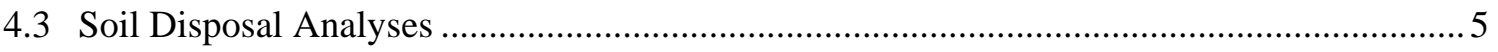

\section{Tables}

Table $1 \quad$ Clay and Soil Sampling and Analysis, Total Constituents

Table $2 \quad$ Clay and Soil Sampling and Analysis, Soluble Constituents

\section{Figures}

Figure B-1 Proposed Verification and Background Sampling Locations

Figure B-2 Liner Section Schematic 


\section{SAMPLING AND ANALYSIS PLAN SITE 300 SURFACE IMPOUNDMENTS CLOSURE}

\subsection{INTRODUCTION}

The field methods and procedures described in this Sampling and Analysis Plan (S\&A Plan) are general descriptions of environmental sampling protocols. The methods described are intended for sampling and analysis relevant to clean closure of the Site 300 Surface Impoundments located at the University of California's Lawrence Livermore National Laboratory. The results will be used to 1) determine appropriate disposal of excavated materials and, 2) to determine if the clay liner and underlying soils meet acceptable criteria for clean closure.

Sampling will be performed on materials collected from three different media associated with the closure project:

- Sampling of the sludge and sand ballast overlying the impoundment geomembrane;

- Sampling of the clay liner underlying the LCRS; and,

- Sampling of soils underlying the clay liner.

The sludge, ballast sand, and LCRS sand will be excavated and disposed of at an appropriate waste management unit. Results from the sludge/ballast sampling event will be used to characterize the LCRS. The recommended testing protocols are intended for soil disposal characterization. It is assumed based on previous testing results that these materials will meet criteria for disposal at a Class II landfill (Altamont Landfill).

The second sampling and analysis event will be on the clay liner and underlying soils to satisfy regulatory criteria for clean closure of the surface impoundments. The excavation subcontractor will provide a backhoe and operator to work with the LLNL sampling technologist to excavate test locations. The LLNL sampling technologist will obtain the samples and submit for analyses per the protocol established herein. Material from the clay liner may be incorporated in the general fill for final grading, depending on the sampling results. 


\subsection{SAMPLING LOCATIONS AND FREQUENCY}

\subsection{Sludge/Ballast Sampling}

It is anticipated that approximately 240 cubic yards (cy) of sludge will be removed from within the impoundments, along with approximately $1,050 \mathrm{cy}$ of sand ballast that lies on top of the geomembrane. Based on the estimated volume above, six (6) composite grab samples will be collected from the sludge and sand ballast (i.e., approximately four composite samples for every 750 cy). Assuming four (4) samples will be collected for each composite sample this is a total of 24 discrete samples. Sixteen (16) grab samples will be obtained from the upper pond, and eight (8) samples will be obtained from the lower pond; four (4) composite samples and two (2) composite samples will be prepared for analytical testing, respectively. The Subcontractor will need to allow time in the construction schedule for analytical testing and authorization for disposal prior to excavation of the sludge and/or ballast.

Sample locations will be determined in the field and will be spaced at approximately equal intervals throughout the floor of the impoundment. Sample locations will be documented on a field map.

\subsection{Clay Liner Sampling}

Samples will be collected from the clay layer underlying the impoundments and submitted for laboratory analysis to investigate whether leaks through the geomembrane have contaminated the clay. Samples for verification of clean closure will be collected from:

- Known leak locations;

- Areas observed to be contaminated based on visual inspection; and

- Specified locations across the clay liner.

There are six documented areas where liner defects were previously discovered and repaired by LLNL (see Section 2.1.3.1 of the Closure Plan for discussion). Two leaks occurred in approximately the same location within the western corner of the upper impoundment. Figure B-1 shows the five general areas of the leaks that will be visually inspected and sampled. In addition, other areas with visual evidence of contamination (soil discoloration, staining, etc.) will also be sampled and submitted for laboratory analysis as discussed in Section 4.0 of this S\&A Plan. Finally, general areas will also be sampled following the grid layout shown on Figure B-1.

In summary, it is anticipated that a minimum of eleven samples will be collected from the clay liner within the upper impoundment, and a minimum of five (5) samples will be collected from the lower impoundment. Five samples are located in areas of suspected leakage (four in the upper impoundment and one in the lower), and the remaining eleven (11) samples are distributed to provide areal coverage of the base of the liner. Additional samples may be collected at the discretion of field personnel based on visual evidence of leakage. This sampling plan will result in approximately 15 sample locations per acre.

Two (2) samples will be collected from each sample location within the clay liner, one at 0-to 6inches within the clay liner, and one at 12-to 18-inches within the liner. The deeper samples will be analyzed if results from the shallower samples indicate that the clay has been contaminated. 
Six (6) background samples for the clay will be collected from the clay liner at locations around the top of the impoundments above the high wastewater elevation (Figure B-1 and B-2). Four (4) background samples will be collected from the upper impoundment and two (2) samples will be collected from the lower impoundment. These samples will be analyzed for the verification sampling parameters using the test methods presented in Section 4.0. The results from these samples will serve as background data for comparing the indicator sample data and determining if leakage through the geomembrane has occurred. Background sampling will be conducted prior to the start of clean closure activities.

\subsection{Subsurface Soils Sampling}

Six (6) samples will be collected from the soils underlying the clay to determine if contaminants have leached through the liner; four (4) from the upper impoundment and two (2) from the lower impoundment. The samples will be collected from 0 - to 12-inches below the bottom of the clay liner. Deeper sampling may be required if evidence of contamination is encountered (see Section 4.6.3 of Final Closure Plan for discussion). These samples will be analyzed for the clean closure monitoring parameters using the test methods presented in Section 4.0 of this S\&A Plan. 


\subsection{SAMPLE COLLECTION AND HANDLING PROCEDURES}

All sampling activities will be conducted by LLNL personnel using LLNL procedures (SOP EO-03, Collecting Samples). Sludge and ballast materials will be collected by LLNL field personnel using a shovel, scoop, auger, or other suitable device. The bulk samples will be composited and transferred to an appropriate container. Each container will be labeled and logged on an appropriate chain-ofcustody form. Approximately 500 grams of materials will be prepared for each composite sample. Sample locations will be documented on a field map. All field equipment in contact with the sample media will be decontaminated between each sample location.

A backhoe will be used to excavate test pits from which the clay liner and native subgrade samples will be collected. Bulk samples will be retrieved from materials excavated from each depth interval using a clean stainless steel scoop, auger or other suitable device, composited, and transferred to an appropriate container. Each container will be labeled and logged on an appropriate chain-of-custody form. Approximately 500 grams of sample media will be prepared for each composite. Sample locations will be documented on a field map. All field equipment in contact with sample media will be decontaminated between each sample location.

Samples will be maintained in a cooler at 4 degrees $\mathrm{C}$, and submitted to a certified analytical laboratory at the end of each work day following standard chain of custody protocol. The samples will be kept in a dark location due to potentially photo-sensitive materials. 


\subsection{SAMPLE ANALYSIS}

\subsection{Clean Closure Verification Analyses}

Clean closure indicator parameters for the clay liner and underlying soils consist of a select list of "indicator parameters" from the existing discharge wastewater monitoring program currently required by the Waste Discharge Requirements (WDR) 96-248 (See Closure Plan Section 4.6.1). The list of indicator monitoring parameters recommended for the clean closure activities consist of:

- $\quad$ Barium, Total in Soil (USEPA Method 6010B);

- Chromium, Total in Soil (USEPA Method 6010B);

- Nickel, Total in Soil (USEPA Method 6010B);

- Zinc, Total in Soil (USEPA Method 6010B);

- $\quad$ Chloride, Total in Soil (USEPA Method 300.0);

- Sulfate, Total in Soil (USEPA Method 300.0); and,

- $\quad$ RDX/HMX (USEPA Method 8330).

The parameters, methods, and reporting limits are provided in Table 1 (attached). Quality assurance/quality control samples will consist of duplicates as specified by LLNL personnel.

\subsection{Clean Closure Contingency Sampling and Analysis}

If exceedances of background for the above listed parameters are observed in native soils underneath the liner, then additional testing for soluble constituents (STLC) will be performed to determine if there is a potential threat to groundwater (Table 2, attached). Only those parameters with exceedances over background will require further testing. The Designated Level Methodology (DLM) (CRWQCB, 1986) will be utilized to determine if water percolating through the subgrade soils will exceed the lowest water quality objective for each of the heavy metals listed above. The Designated Level Methodology entails determining extractable waste constituent concentrations using the California Waste Extraction Test (WET) procedure (Title 22, CCR, §66700). For this application, it is recommended that the extraction be performed using de-ionized water since the future source water for any percolation through the native soils is naturally occurring rainfall. Although there is no background concentration for RDX and HMX, the DLM would also be performed for RDX and HMX to determine the threat to groundwater quality if they were detected.

\subsection{Soil Disposal Analyses}

A full suite of analyses was previously performed by LLNL on sludge from the upper and lower impoundments (Table 2, Final Closure Plan). One sample was collected from each impoundment and a duplicate sample was also collected for the upper impoundment. This data showed the sludge to be non-hazardous. 
The impoundment waste materials will be considered "special waste" by landfill disposal facilities and will require a "Generator Waste Profile" along with appropriate analytical backup. The generator must certify that the materials are non-hazardous per 22CCR §66260, and must also provide representative analyses based on the nature of the waste.

For off-site disposal associated with this project, the sludge/sand ballast samples will be analyzed for:

- $\quad$ STLC CAM 17 Metals (USEPA 6000/7000 series);

- Total CAM 17 Metals (USEPA 6000/7000 series);

- TCLP ZERO Extraction (USEPA method 8021); and,

- High Explosives (USEPA method 8330).

The impoundment waste materials will be considered "special waste" by landfill disposal facilities and will require a "Generator Waste Profile" along with appropriate analytical backup. The generator must certify that the materials are non-hazardous per 22CCR §66260, and must also provide representative analyses based on the nature of the waste.

It is recommended that the Generator Waste Profile, existing backup analytical data, and proposed analytical sampling frequency and analytical methods be presented for pre-approval to the selected waste facility at least two weeks prior to the start of the construction phase of the project. Once preapproval has been obtained, the above off-site disposal analyses data verifying the non-hazardous nature of the soils should be submitted to the selected waste disposal facility for approval prior to transport of the soils to the facility. For this project, the Altamont Class II Landfill has been identified as the selected waste disposal facility. 
TABLES 


\section{TABLE 1}

\section{CLAY AND SOIL SAMPLING AND ANALYSIS \\ Total Constituents}

\begin{tabular}{|c|c|c|c|c|c|}
\hline & $\begin{array}{l}\text { LLNL's } \\
\text { Parameter } \\
\text { Code }\end{array}$ & $\begin{array}{l}\text { Preparation } \\
\text { Method }\end{array}$ & $\begin{array}{l}\text { Analysis } \\
\text { Method }\end{array}$ & $\begin{array}{l}\text { Reporting } \\
\text { Limit } \\
\text { (mg/kg) }\end{array}$ & $\begin{array}{l}\text { Site-Specific } \\
\text { Background } \\
\text { (mg/kg) }\end{array}$ \\
\hline \multicolumn{6}{|c|}{$\underline{\text { Total Metals (TTLC) }}$} \\
\hline Barium & 0475 & $3050 \mathrm{~B}^{\mathrm{a}}$ & EPA 6010B & $5-10$ & $\mathrm{tbd}^{\mathrm{b}}$ \\
\hline Chromium (total) & 2450 & $3050 \mathrm{~B}^{\mathrm{a}}$ & EPA 6010B & $5-10$ & tbd \\
\hline Nickel & 5850 & $3050 B^{a}$ & EPA 6010B & 10 & tbd \\
\hline Zinc & 9050 & $3050 B^{a}$ & EPA 6010B & $5-10$ & tbd \\
\hline \multicolumn{6}{|l|}{ Total Minerals } \\
\hline Chloride & 1950 & $\begin{array}{l}\text { EPA-approved } \\
\text { method }\end{array}$ & EPA 300.0 & 5 & tbd \\
\hline Sulfate & 8025 & $\begin{array}{l}\text { EPA-approved } \\
\text { method }\end{array}$ & EPA 300.0 & 5 & tbd \\
\hline \multicolumn{6}{|c|}{ Energetic Compounds } \\
\hline $\mathrm{HMX}$ & 4935 & $\begin{array}{l}\text { EPA-approved } \\
\text { method }\end{array}$ & EPA 8330 & 0.2 & na \\
\hline RDX & 7125 & $\begin{array}{l}\text { EPA-approved } \\
\text { method }\end{array}$ & EPA 8330 & 0.2 & na \\
\hline
\end{tabular}

TTLC $=$ Total Threshold Limit Concentration

${ }^{a}$ or approved EPA Method

${ }^{\mathrm{b}} \mathrm{tbd}=$ To be determined from site-specific clay "background" samples 
TABLE 2

\section{CLAY AND SOIL SAMPLING AND ANALYSIS}

Soluable Constituents

\begin{tabular}{|c|c|c|c|c|}
\hline & $\begin{array}{c}\text { LLNL's } \\
\text { Parameter } \\
\text { Code }\end{array}$ & $\begin{array}{l}\text { Leaching } \\
\text { Method }\end{array}$ & $\begin{array}{l}\text { Analysis } \\
\text { Method }\end{array}$ & $\begin{array}{c}\text { Reporting } \\
\text { Limit } \\
(\mathrm{mg} / \mathrm{L})\end{array}$ \\
\hline \multicolumn{5}{|c|}{ Soluable Metals (STLC) } \\
\hline Barium & 0475 & $C A W E T^{a}$ & $\begin{array}{c}\text { EPA } 6010 B \\
\text { or } 6020\end{array}$ & $0.5-1.0$ \\
\hline Chromium (total) & 2450 & CA WET & $\begin{array}{c}\text { EPA } 6010 B \\
\text { or } 6022\end{array}$ & 0.5 \\
\hline Nickel & 5850 & CA WET & $\begin{array}{c}\text { EPA } 6010 B \\
\text { or } 6024\end{array}$ & $0.5-1.0$ \\
\hline Zinc & 9050 & CA WET & $\begin{array}{c}\text { EPA } 6010 B \\
\text { or } 6026\end{array}$ & 1.0 \\
\hline \multicolumn{5}{|l|}{$\underline{\text { Soluable Minerals }}$} \\
\hline Chloride & 1950 & CA WET & EPA 300.0 & $5-10$ \\
\hline Sulfate & 8025 & CA WET & EPA 300.0 & $5-10$ \\
\hline \multicolumn{5}{|c|}{ Soluable Energetic Compounds } \\
\hline HMX & 4935 & CA WET & EPA 8330 & $0.005-0.01$ \\
\hline $\mathrm{RDX}$ & 7125 & CA WET & EPA 8330 & $0.005-0.01$ \\
\hline
\end{tabular}

STLC $=$ Soluble Threshold Limit Concentration

${ }^{a}$ California Waste Extraction Test (leached with deionized water) 
FIGURES 


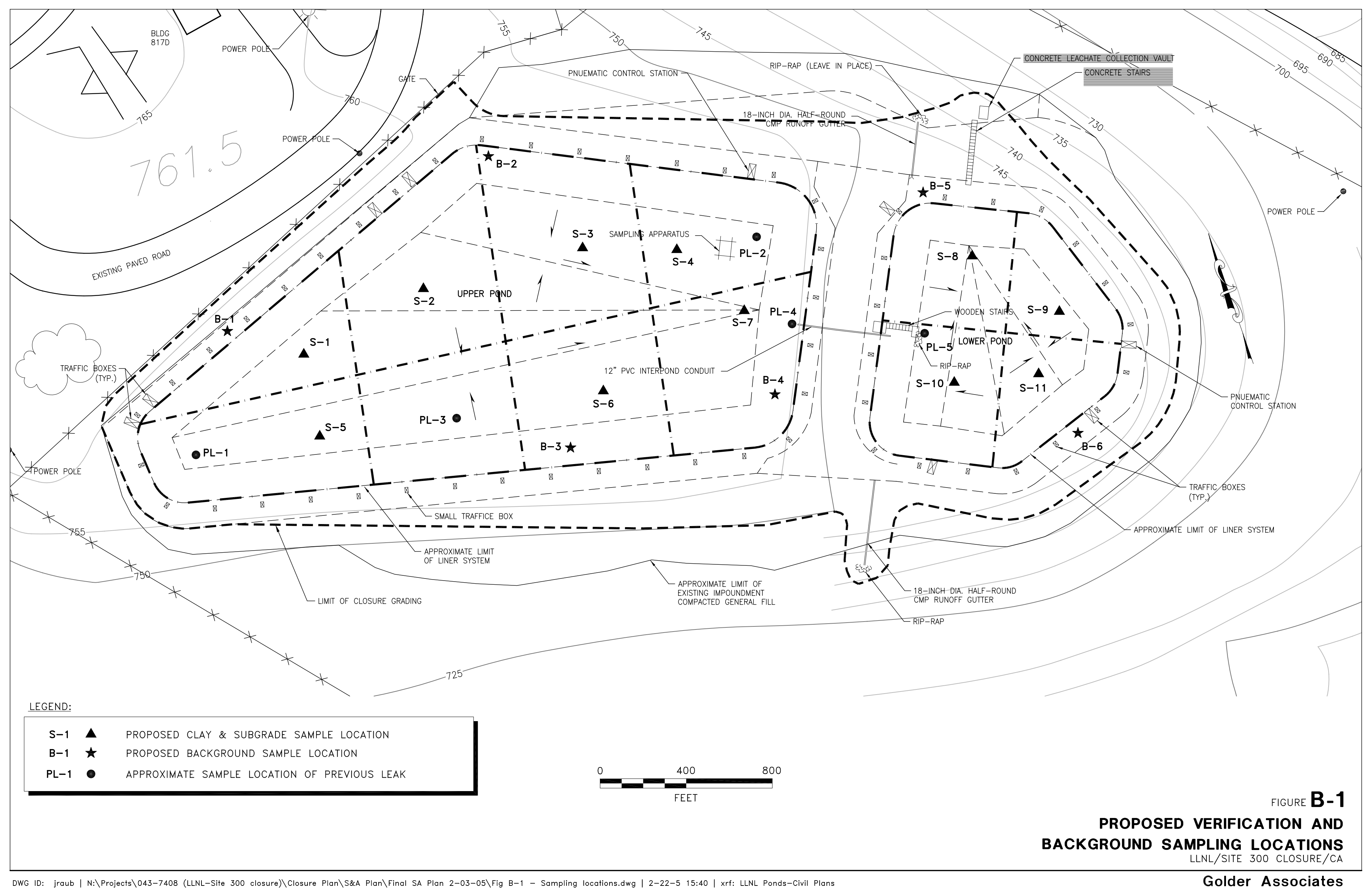




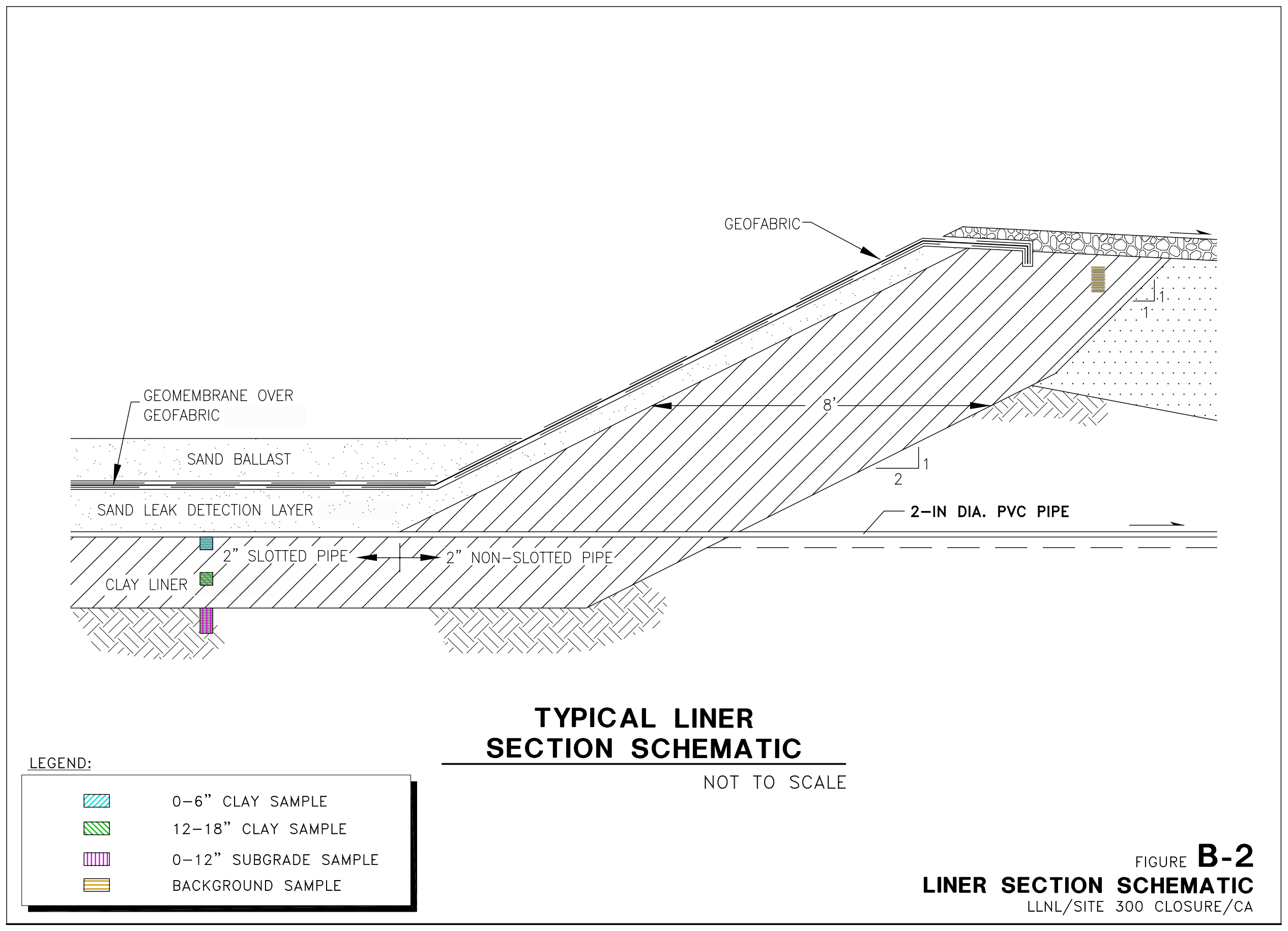

DWG ID: jraub | N:\Projects\043-7408\Closure Plan\S\&A Plan\Final SA Plan 2-03-05\Fig B-2 - Liner Section.dwg | 2-22-5 15:46 | xrf: LLNL Ponds-Civil Details Golder AsSOCiates 
APPENDIX C CONSTRUCTION PLANS 


\section{SURFACE IMPOUNDMENTS CLOSURE LLNL - SITE 300}
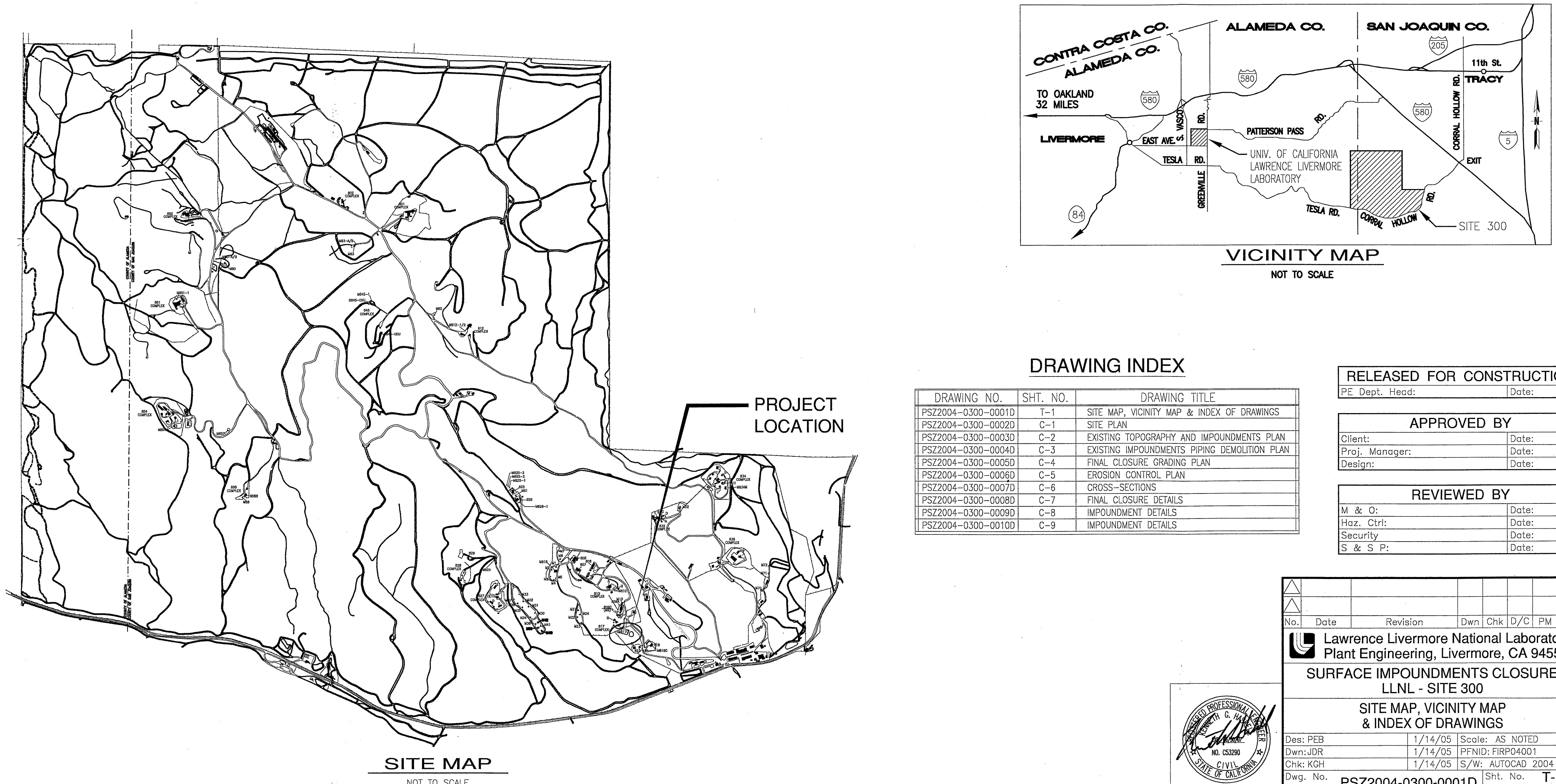

DRAWING INDEX

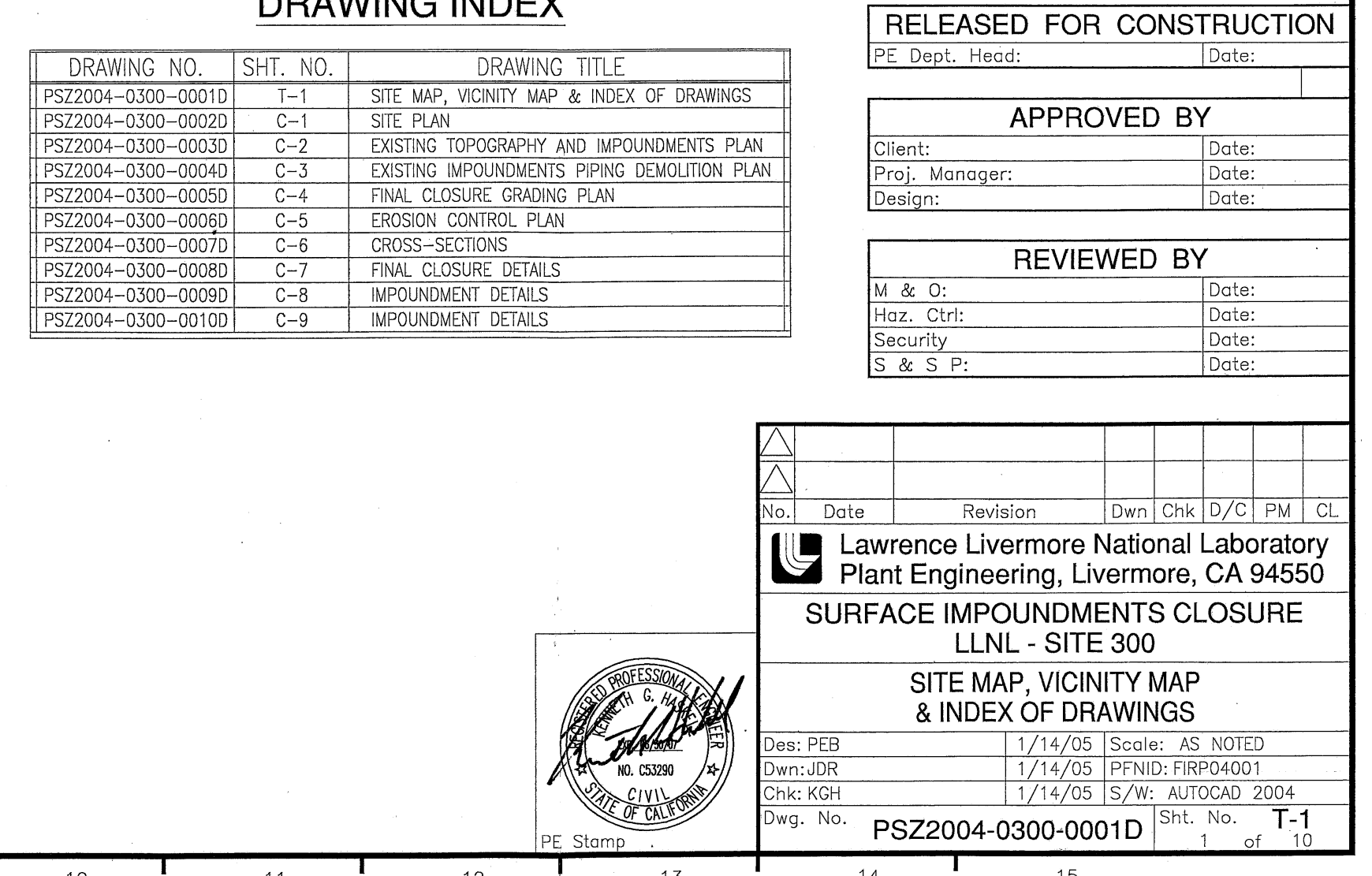




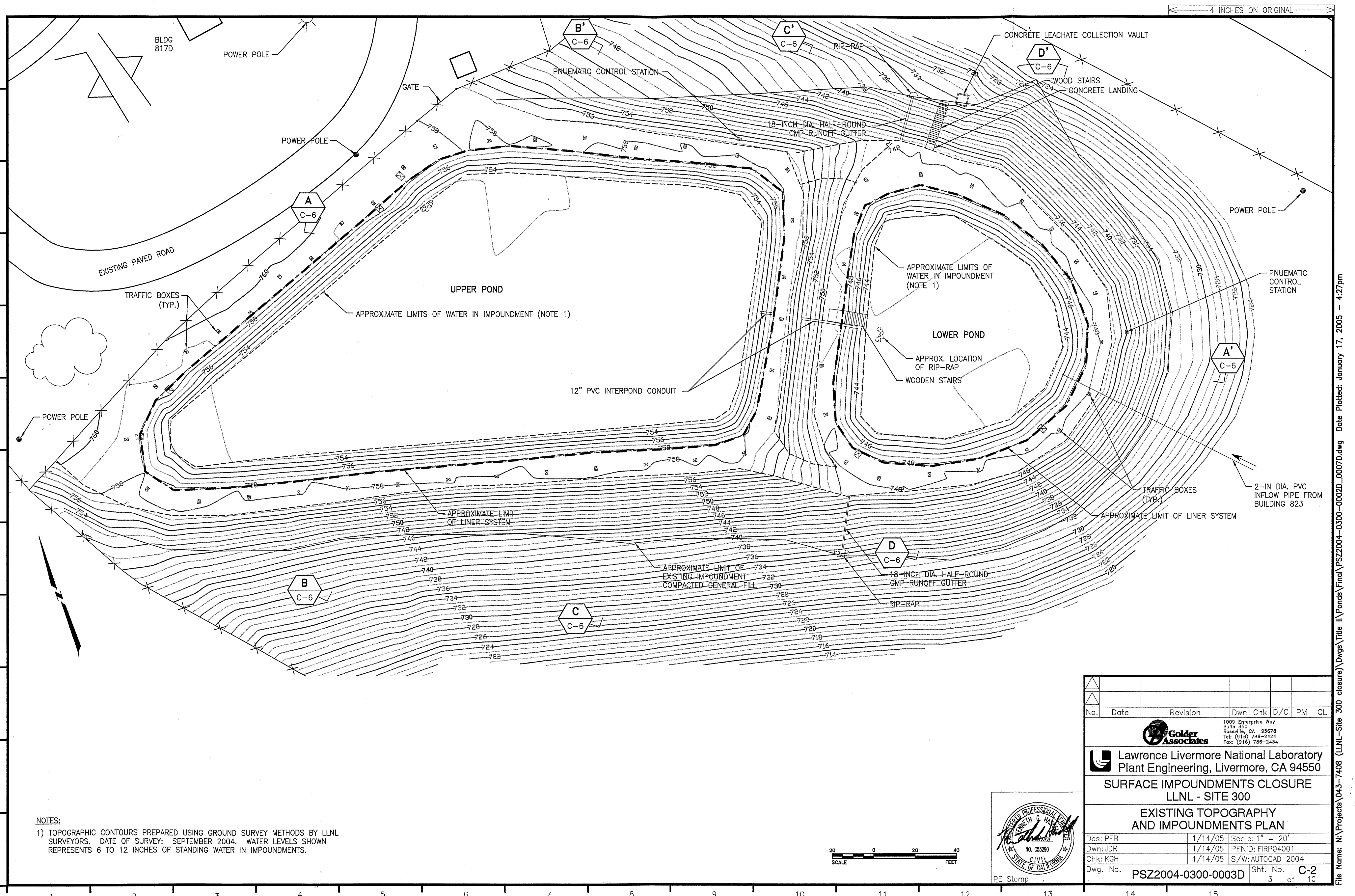




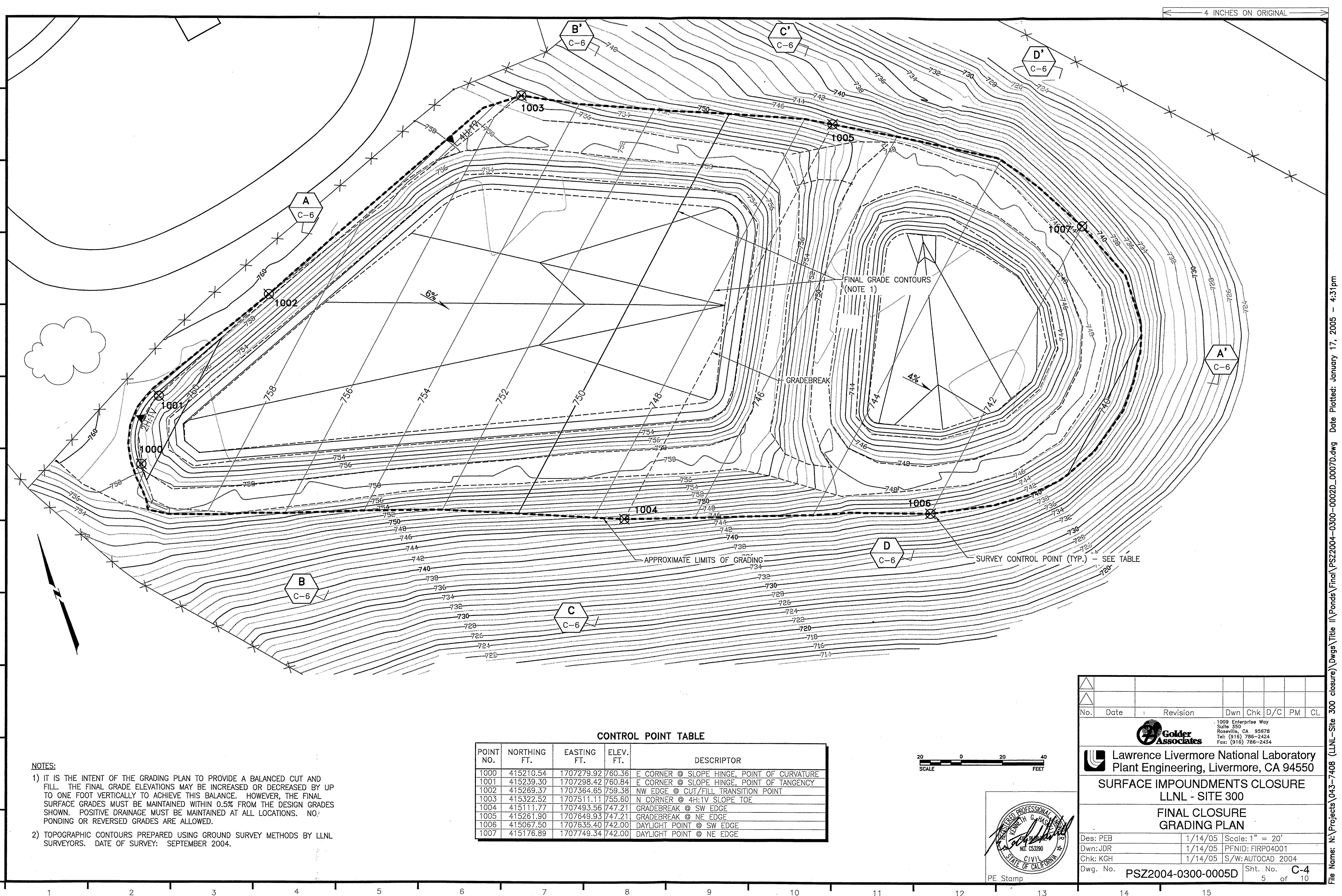




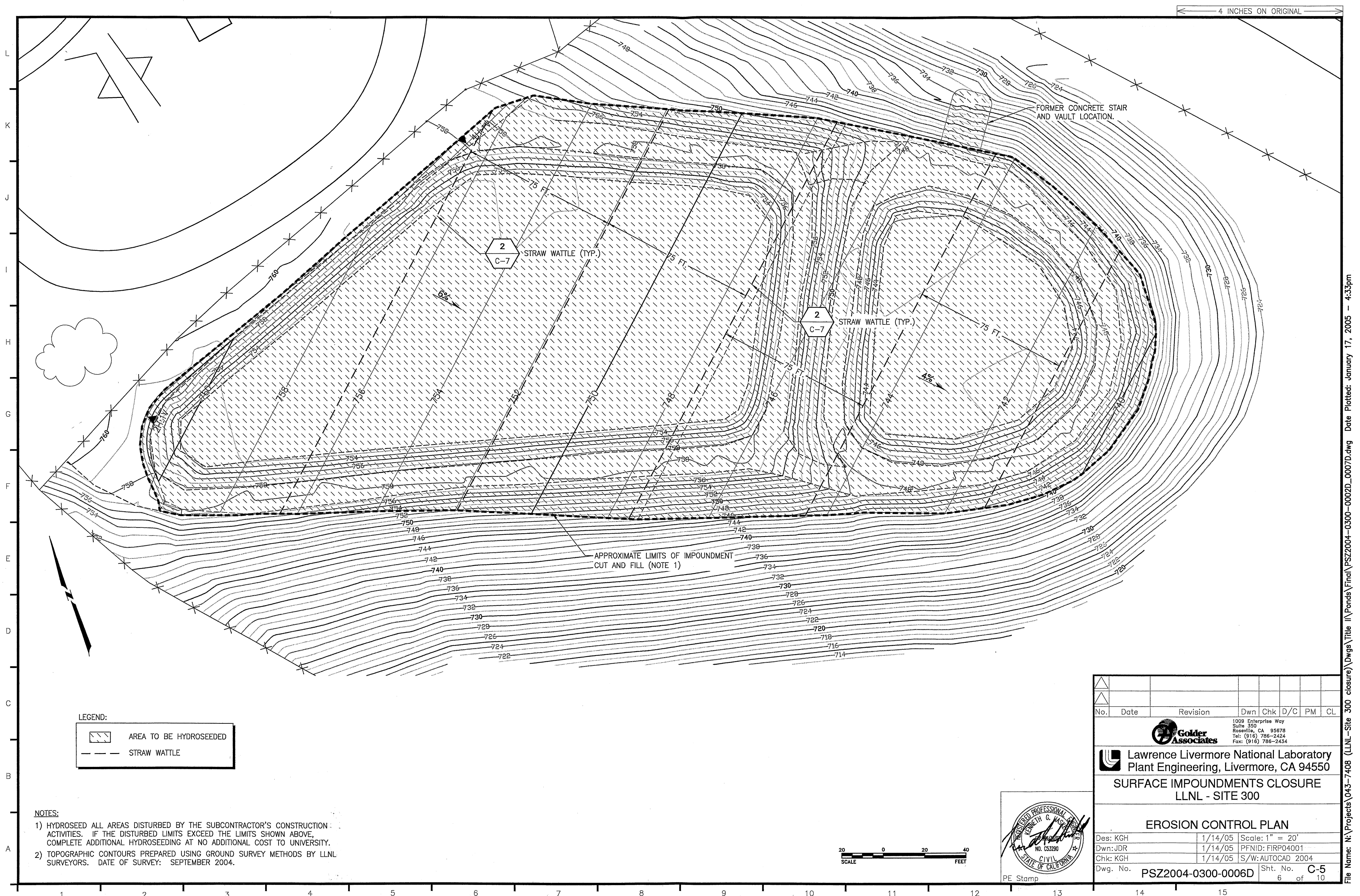


A (NORTHWEST)

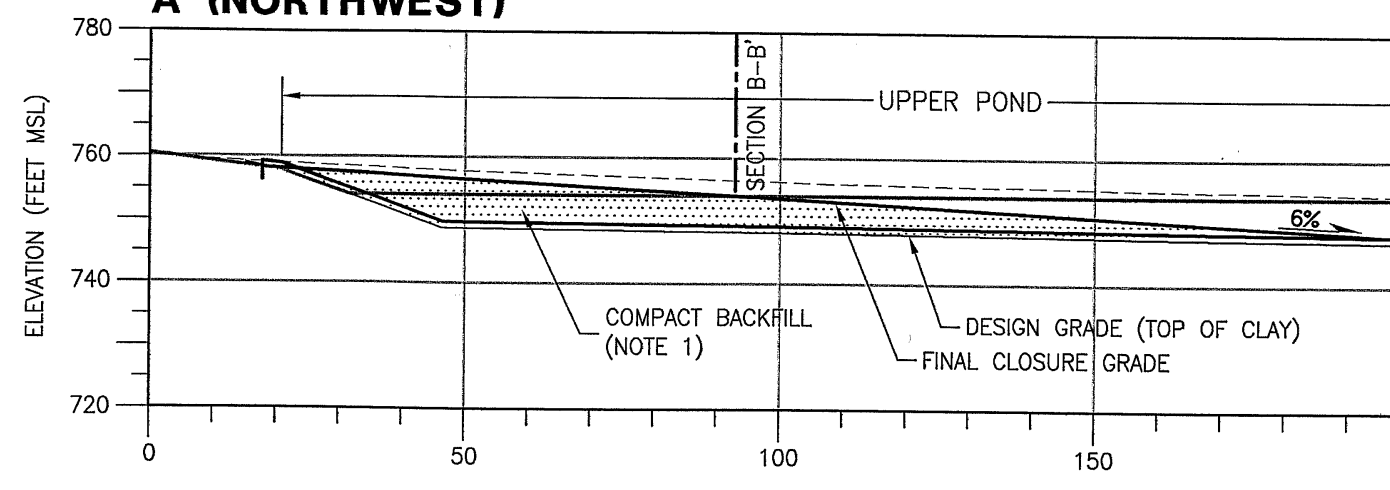

(SOUTHEAST) A'

NOTES:

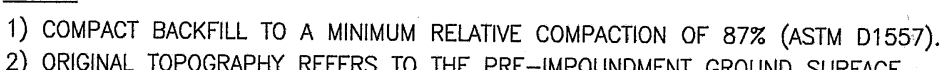
3) EXISTING LINER COMPONENTS ABOVE THE CLAY LINER SHALL BE REMOVED AND
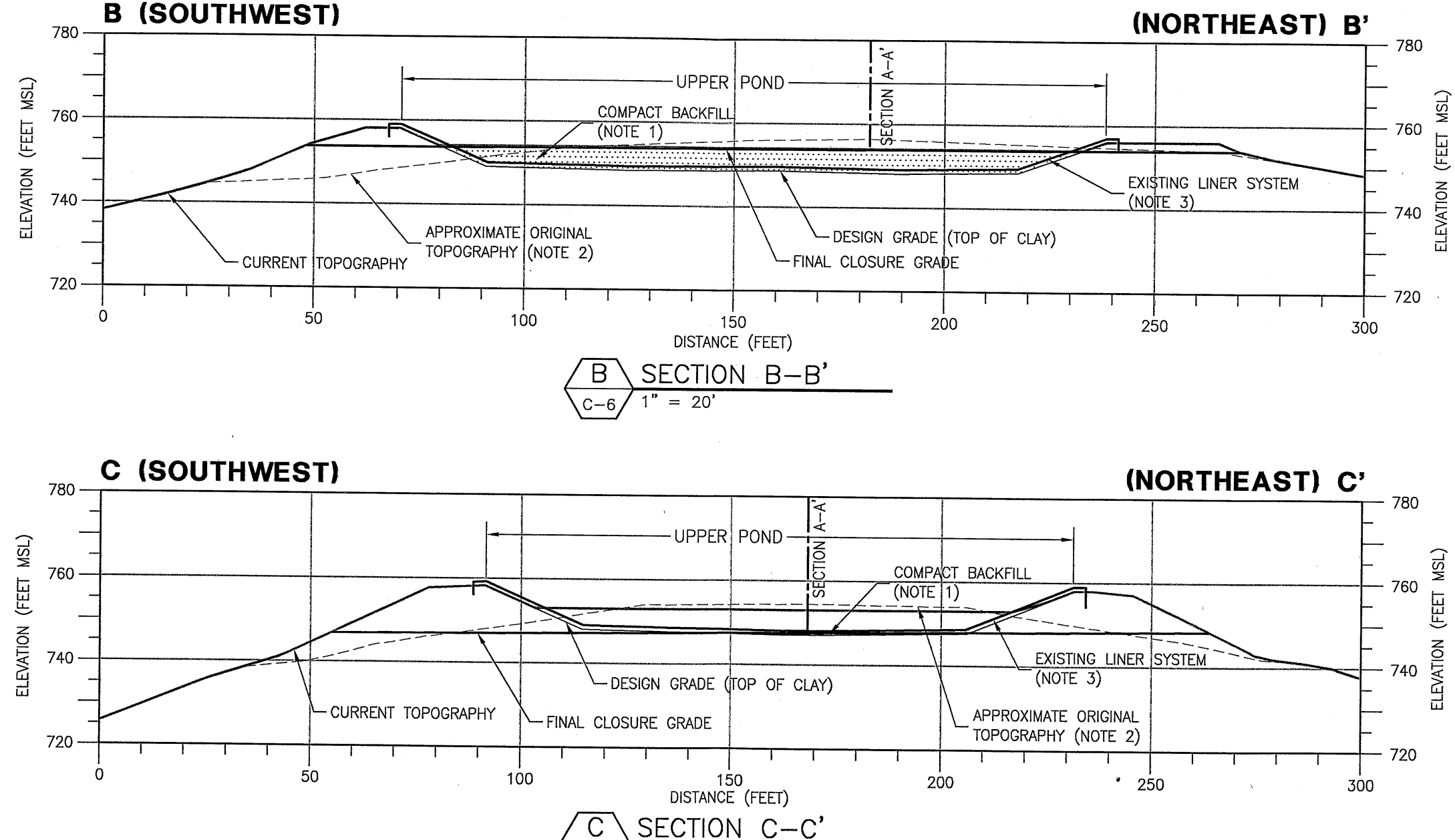

\begin{tabular}{|c|c|c|}
\hline$C$ & SECTION & C-C' \\
\hline$C-6$ & $1^{\prime \prime}=20^{\prime}$
\end{tabular}

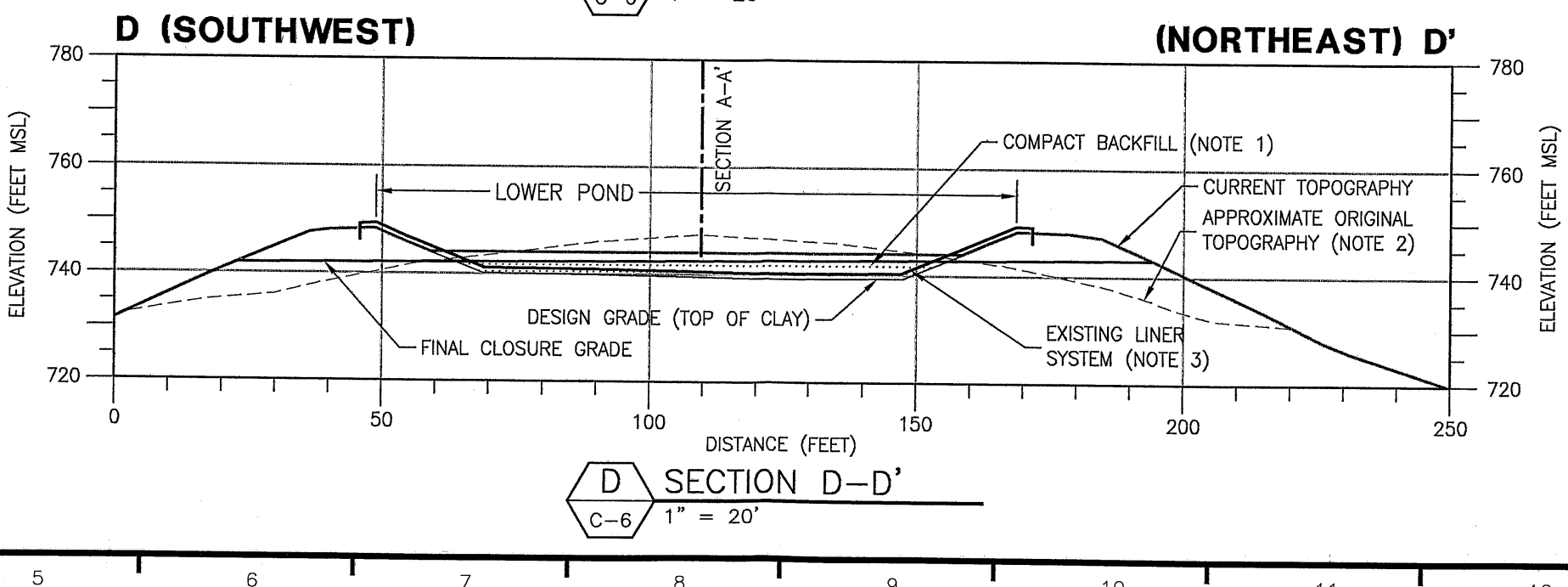

(NORTHEAST) B'
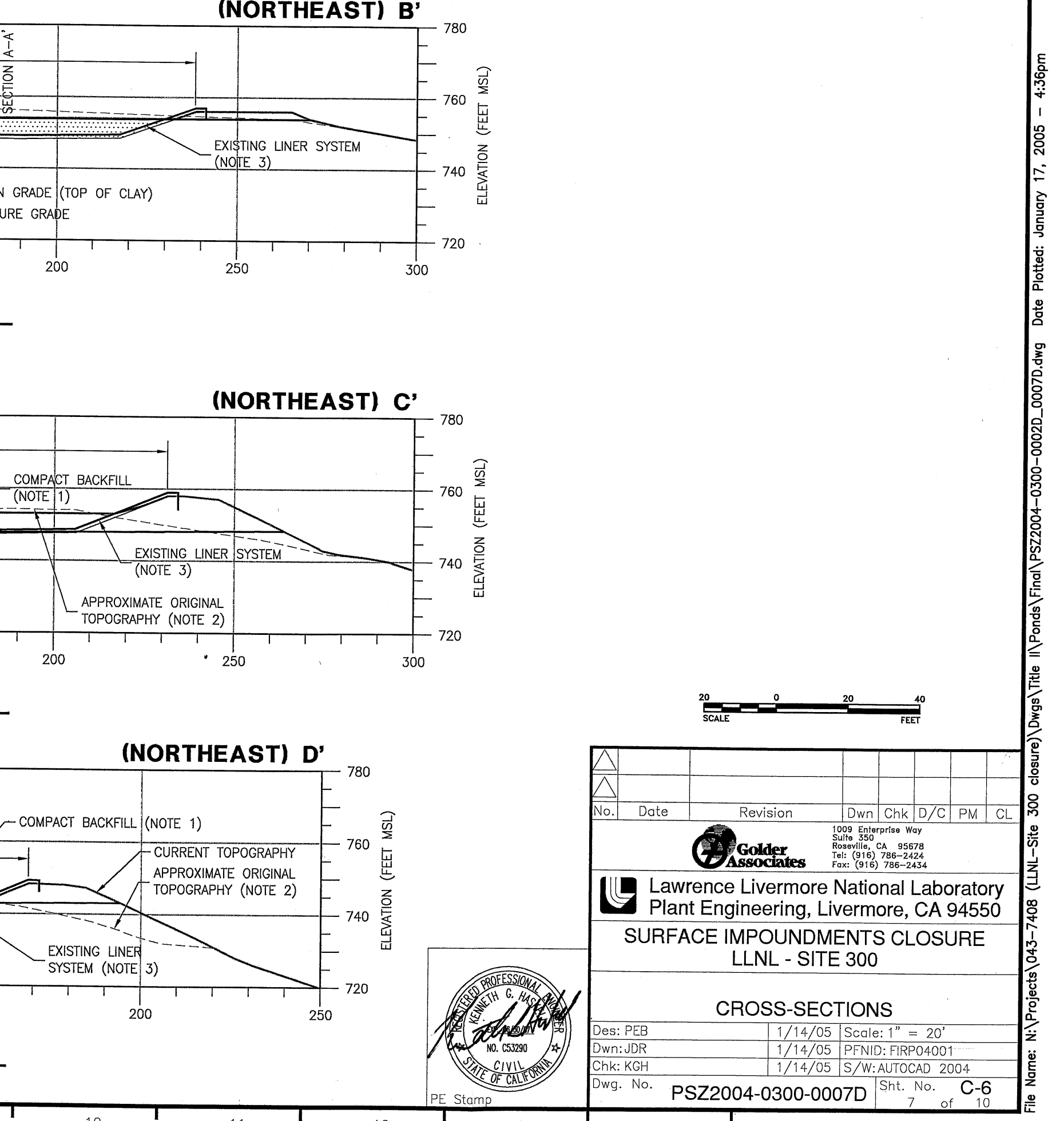


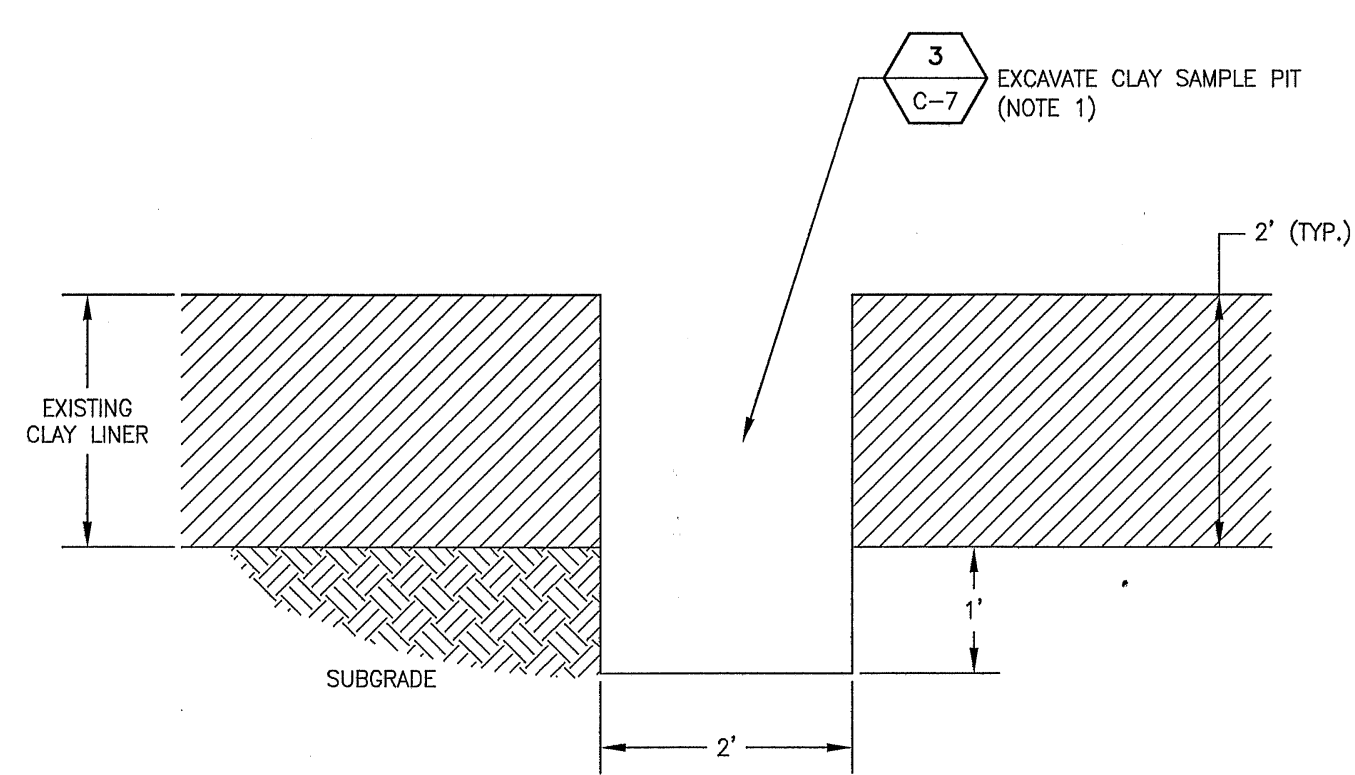

\begin{tabular}{l|l}
1 & CLAY SAMPLE PIT \\
$c-7$ & $1^{\prime \prime}=1^{1}-0^{\prime \prime}$
\end{tabular}

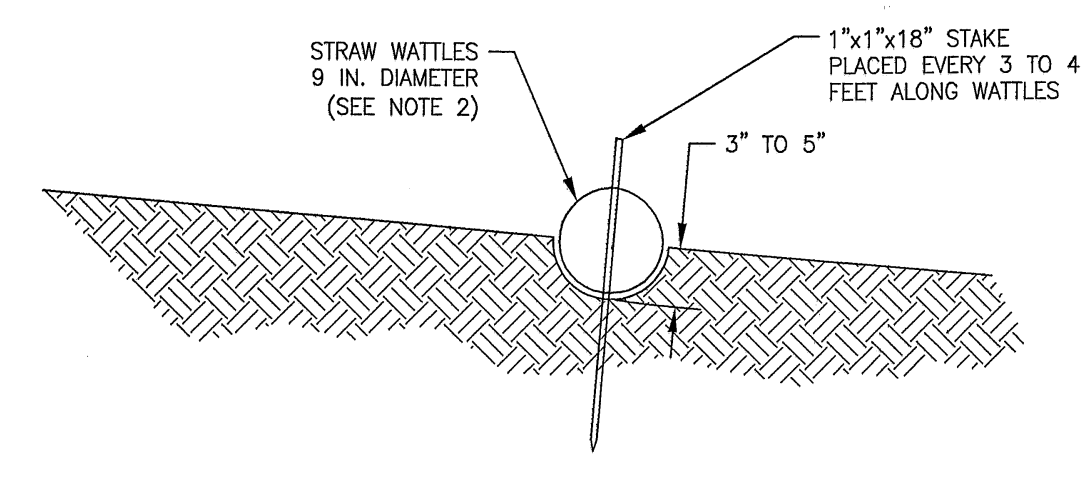

\begin{tabular}{|c|c|c|}
2 & TYPICAL STRAW WATTLE \\
\hline$c-7$ & $1^{1 n}=1^{\prime}-0^{n}$ & \\
\hline
\end{tabular}

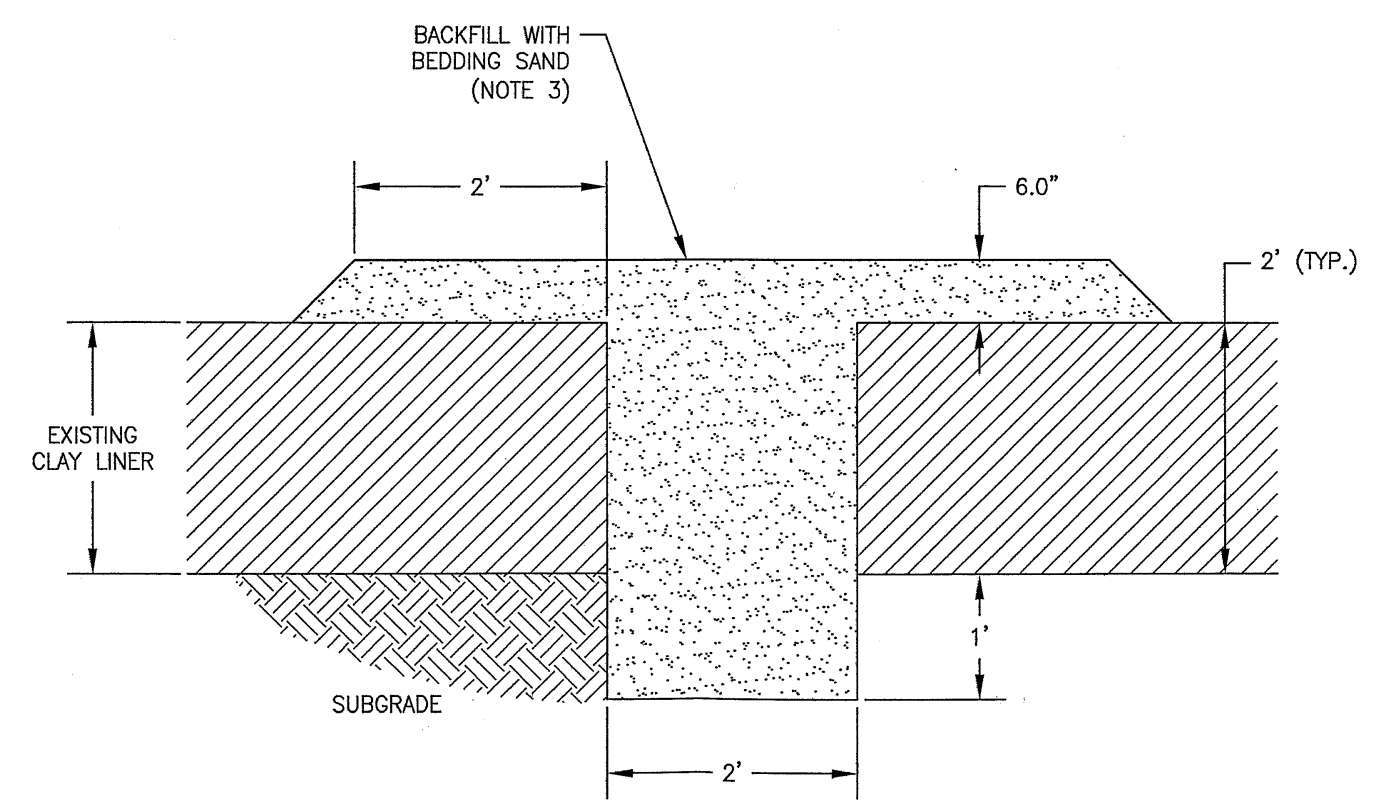

1) CLAY SAMPLE PIT SHALL MEASURE A MINMUM OF $2 \mathrm{FT}$ (WIDTH) BY

\begin{tabular}{c|c}
3 & BACKFILLED CLAY SAMPLE PIT \\
\hline$c-7$ & $1^{n}=1^{\prime}-0^{\prime \prime}$
\end{tabular}

G)

(15) Lawrence Livermore National Laboratory SURFACE IMPOUNDMENTS CLOSURE LLNL - SITE 300

FINAL CLOSURE DETAILS

PIACE STPAW WATLES GENERALLY PARALLEL TO SLOPE CONTOURS.

3) AFER UNNERSIY VERRFES CLEAN CLOSURE, BACKFILL CLAY SAMPLE
PIT WITH BEDDING SAND. COMPACT SAND BY TRACK WALKKING OVER

THE SURRAC WTH DODER, TRUCK, OR OTHER EQUUPMENT
APPROVED BY ENGINERE. 

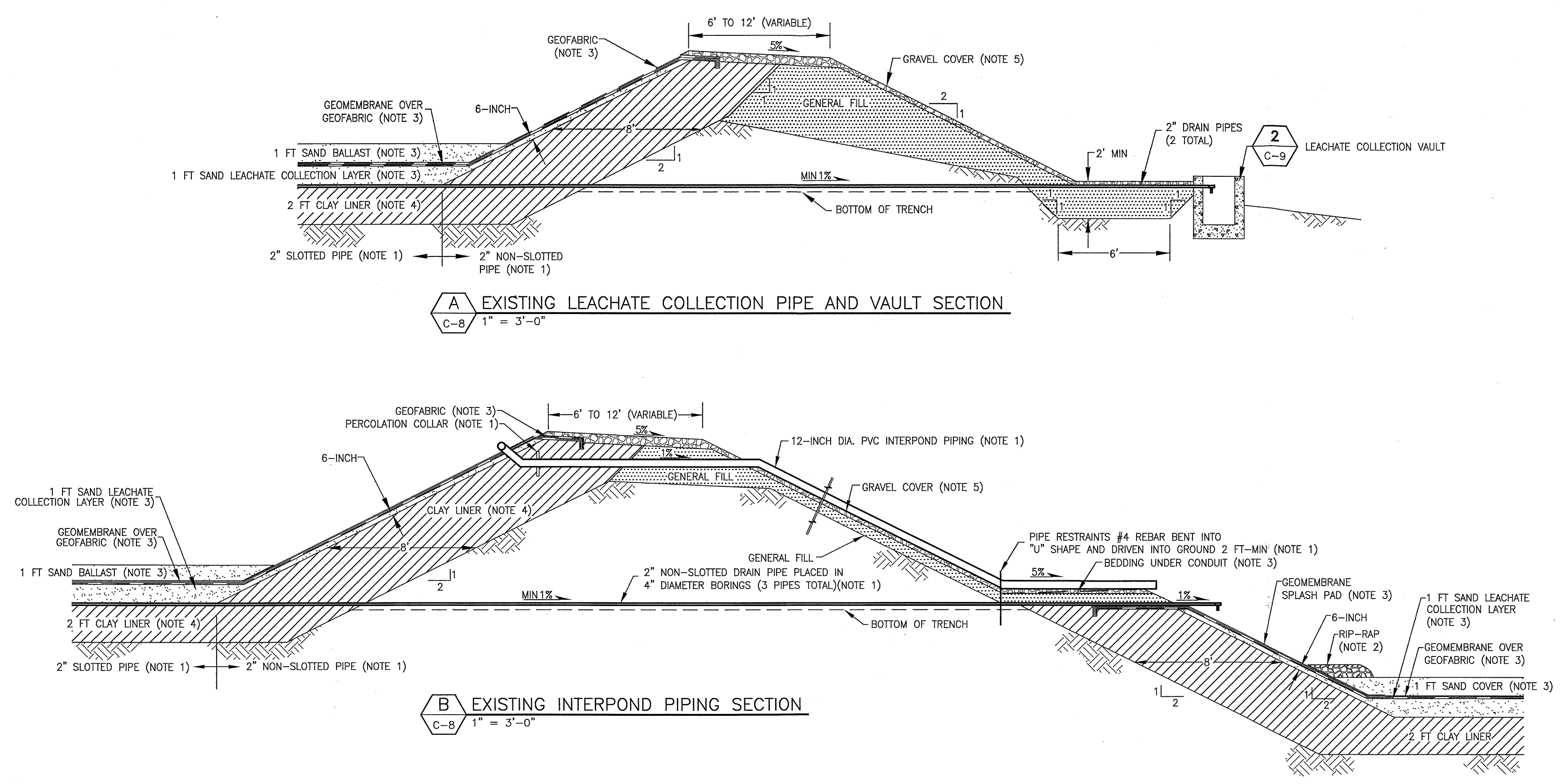

NOTES:

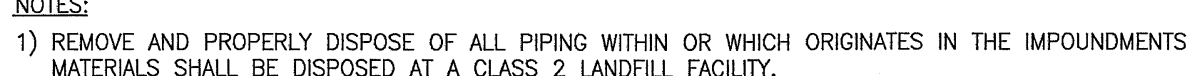

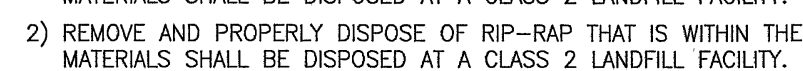

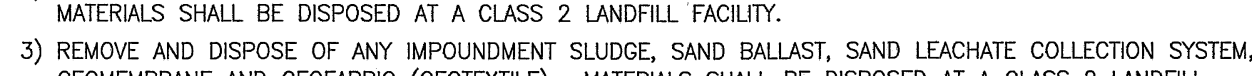

FACLITY.

4) CLAY LNER TO REMAIN UNLESS OTHERWISE DREETED BY THE
5) GRAVEL COVER MAY BE USED FOR IMPOUNDMENT BACKFILL

\begin{tabular}{l} 
A EXISTING LEACHATE COLLECTION PIPE AND VAULT SECTION \\
\hline$c-8$. \\
$1^{\prime \prime}=3^{\prime}-0^{n}$
\end{tabular} 


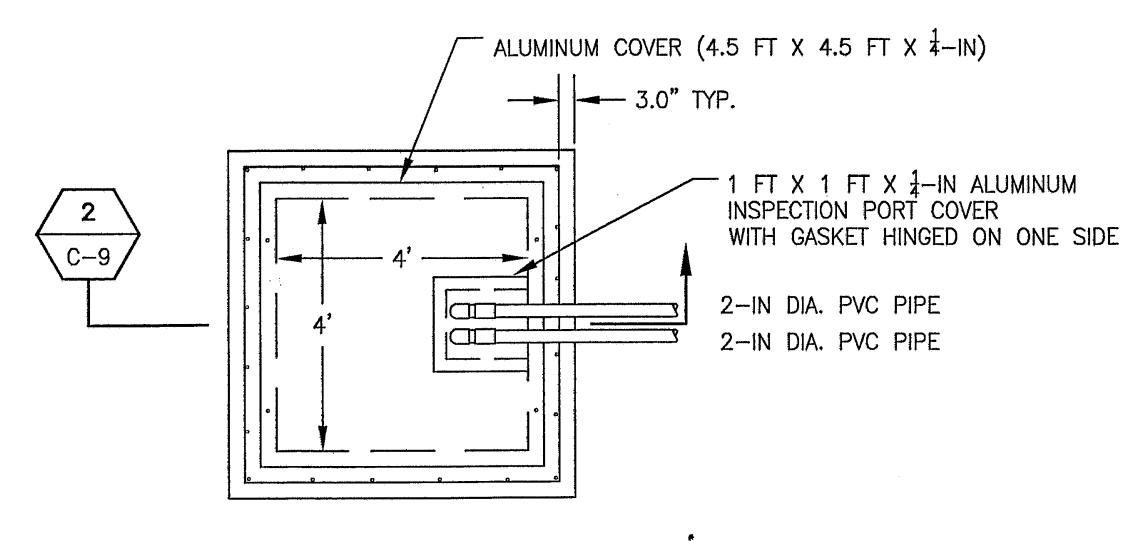

\begin{tabular}{c|c}
1 & EXISTING LEACHATE COLLECTION VAULT PLAN \\
\hline$c-9$ & $1^{\prime \prime}=1^{\prime}-0^{\prime \prime}$
\end{tabular}

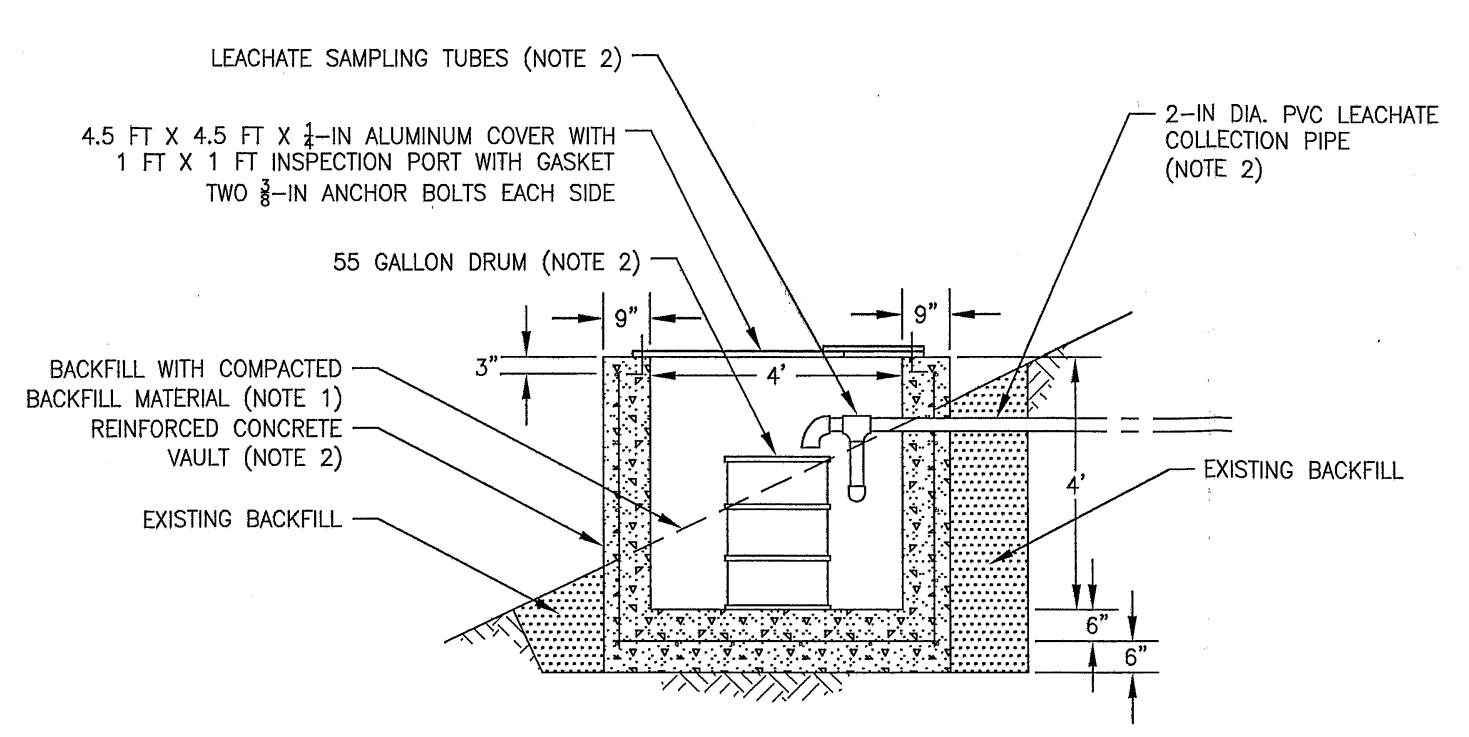

\begin{tabular}{c|c}
2 & EXISTING LEACHATE COLLECTION VAULT PROFILE \\
\hline$C-9$ & $1^{\prime \prime}=1^{\prime}-0^{\prime \prime}$
\end{tabular}

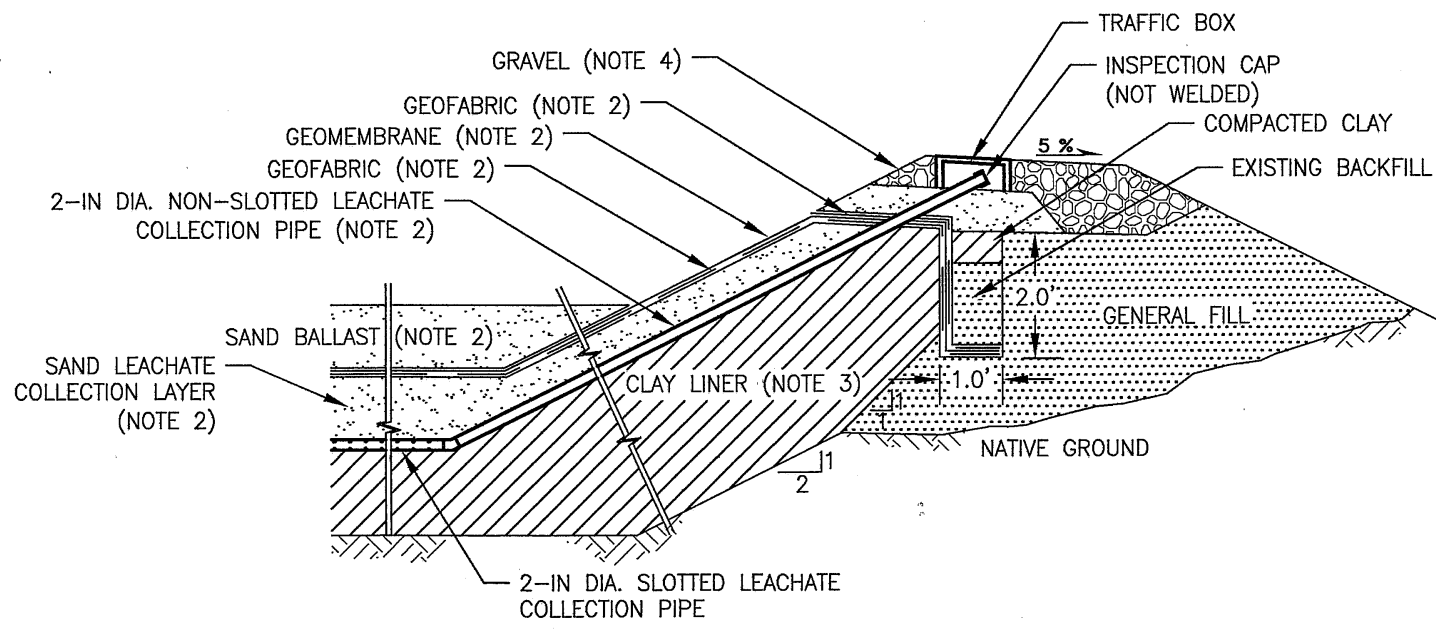

EXISTING LEACHATE COLLECTION PIPE TERMINATION 3. AND GEOMEMBRANE ANCHOR DETAIL

NOTES:

AFTER REMOING THE VAUT, FILL REMAING DEPRESSION WTH BACKFLL TO MATCH
THE SURROUNDING GRADES. COMPACT BACKFIL TO A MINIMUM. REATTIE COMPACTION OF 87\% (ASTM D1557).

2) REMOVE AND DISPOSE OF PIPES, VAULTS, DRUM, AND LINER COMPONENTS. 3) CLAY LINER TO REMAIN UNLESS OTHERWIE DIRECTED BY THE UNIVERSITY. 4) GAVEL MAY BE USED AS MPPOUNDMENT BACKFLL.

5) SUBCONTRACTOR TO LOCATE AND REMOOE LYIIIEERER AND TUBING. LYSIMETER AND
TUBING TO BE DISPOSED OF AT A CLASS 2 LANDFIL FACLIITY.

6) CLEAN SAND BEDDING, AND CONCRETE AND COMPACTED CLAY SEAL MAY BE USED
AS IMPOUNDMENT BACKFIL.

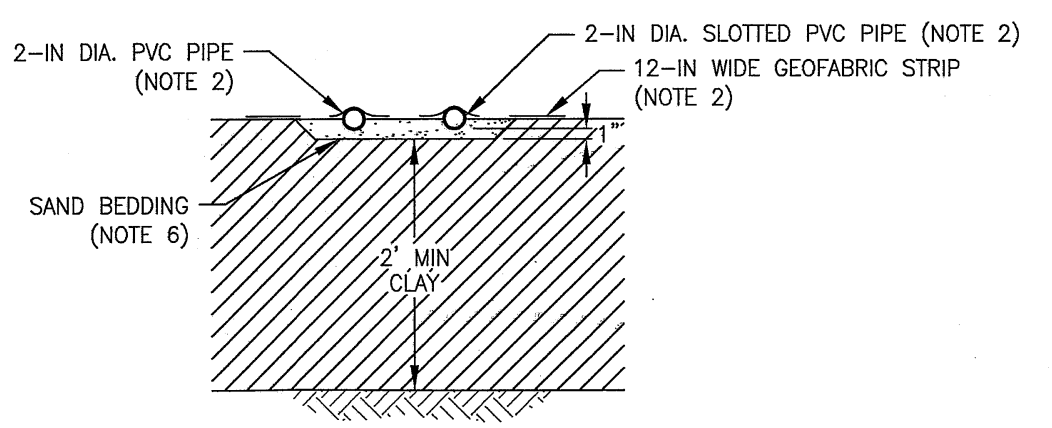

TYPICAL EXISTING LEACHATE \begin{tabular}{c|c|c|c|}
4 & COLLECTION PIPE BEDDING \\
\hline$C-9$ & $1^{n}=1^{\prime}-0^{n}$
\end{tabular}

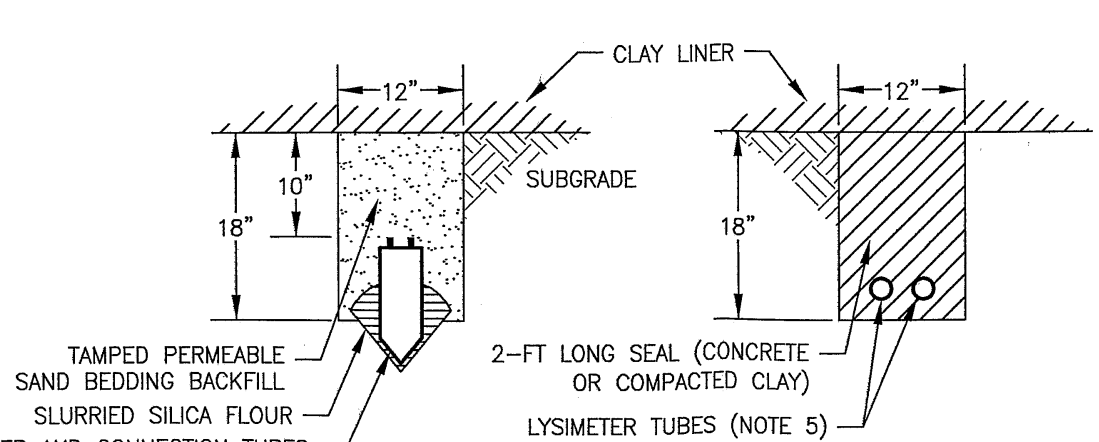
SLURRELD SILLA FLOUR -
YYSMETER AND CONNECTOOL TURES

OR COMPACTED CLAY)

(NOTE 5) LYSIMETER

IRENCH SEAL

\begin{tabular}{c|c|c|c|}
\hline 6 & TYPICAL EXISTING LYSIMETER SYSTEM \\
\hline$c-9$ & $1^{\prime \prime}=1^{\prime}-0^{\prime \prime}$
\end{tabular}

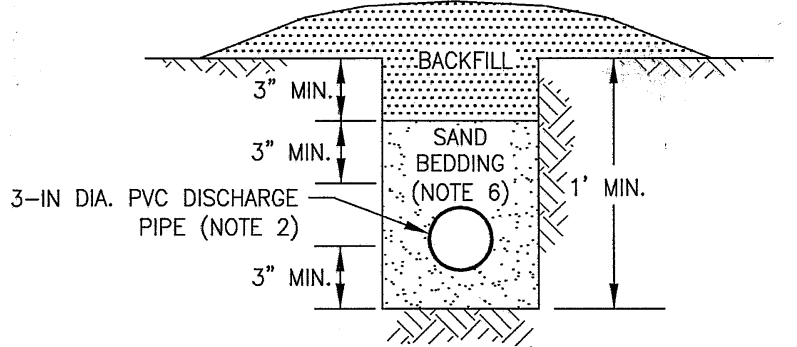

TYPICAL EXISTING 3" PVC \begin{tabular}{c|c}
5 & WASTE WATER PIPELINE SECTION \\
$c-9$ & $1^{\prime \prime}=0^{\prime}-6^{\prime \prime}$
\end{tabular}

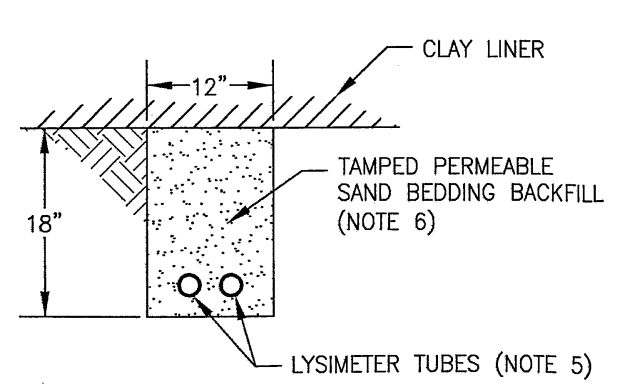

LYSIMETER TUBES (NOTE 5)

YSIMETER TUBING TRENCH

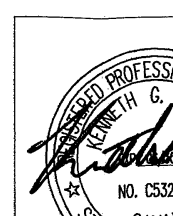

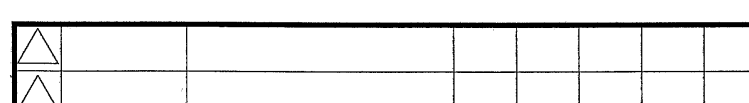

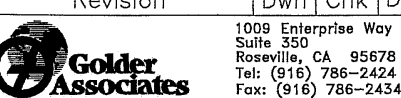

(15) Lawrence Livermore National Laboratory SURFACE IMPOUNDMENTS CLOSURE LLNL - SITE 300

IMPOUNDMENT DETAILS \begin{tabular}{l|l|l} 
& $1 / 14 / 05$ & Scale: AS SHOWN \\
& $1 / 14 / 05$ & PFNI: FIRP04001 \\
\hline
\end{tabular} 1/14/05 S/W:AUTOCAD 2004
PSZ2004-0300-0010D
Sht. No. C-9 


\section{APPENDIX D}

CONSTRUCTION SPECIFICATIONS 


\title{
SPECIFICATION OCS-0141 \\ DIVISION 2 - SITE WORK \\ SURFACE IMPOUNDMENTS CLOSURE
}

\author{
SITE 300
}

\author{
Prepared for \\ UNIVERSITY OF CALIFORNIA \\ LAWRENCE LIVERMORE NATIONAL LABORATORY \\ PLANT ENGINEERING \\ Livermore, California 94550
}

Prepared by

Golder Associates Inc.

1009 Enterprise Way, Suite 350

Roseville, CA 95678 
This page intentionally left blank 


\section{PROFESSIONAL CERTIFICATION}

The designs, specifications, and drawings comprising this subcontract have been prepared by or under the cognizance of registered professional engineers holding a valid license in the State of California issued by the State Board of Registration for Professional Engineers and/or licensed architects holding valid licenses in the State of California issued by the Board of Architectural Examiners.
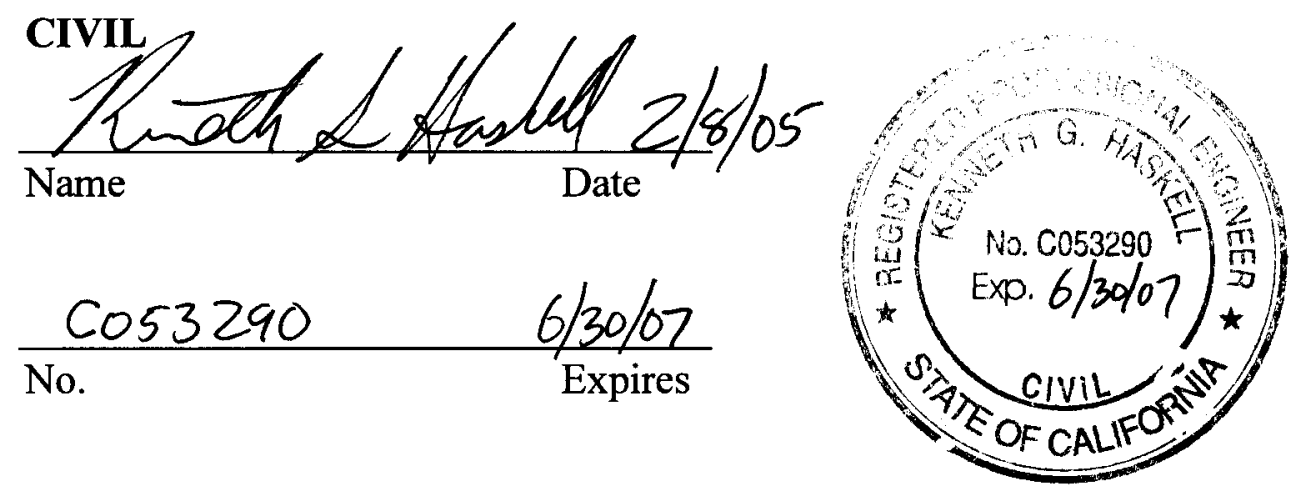
This page intentionally left blank 


\section{TABLE OF CONTENTS}

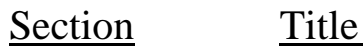

DIVISION 2 SITEWORK

$02061 \quad$ Impoundment Demolition, Salvage, and Disposal

$02200 \quad$ Earthwork

$02940 \quad$ Erosion Controls

END OF TABLE OF CONTENTS 
This page intentionally left blank 


\section{SECTION 02061 — IMPOUNDMENT DEMOLITION, SALVAGE, AND DISPOSAL}

\section{PART 1 GENERAL}

1.01 SECTION INCLUDES
A. Demolition
B. Salvage
C. Disposal

$1.02 \quad$ RELATED SECTIONS

A. Section 01400 “Quality Control”

B. Section 02200 "Earthwork"

1.03 REFERENCES

A. The following documents form a part of these specifications to the extent stated herein.

B. State of California Code of Regulations (CCR)

B.1 CCR Title 8 Industrial Relations; Chapter 4 - Division of Industrial Safety (DIS):

SubCh 4. Construction Safety Orders

SubCh $5 . \quad$ Electrical Safety Orders

SubCh $7 . \quad$ General Industry Safety Orders

B.2 CCR Title $27 \quad$ Environmental Protection

C. State of California (CAL)

C.1 CAL Labor Code Div 5: Safety in Employment

Ch 9. Miscellaneous Labor Provisions:

Sec 6705. Protection of Workers Excavating Trenches

Sec 6707. Call for Bids On Government Contracts Requiring Excavations to Contain Item for Protection of Workers

D. Sampling and Analysis Plan, Site 300 Surface Impoundments Closure, Lawrence Livermore National Laboratories, September 2004. 


\section{$1.04 \quad$ SUBMITTALS}

A. Submit project record documents under provisions of section 01300 "Submittals".

A.1 Submit records that clearly delineate the final disposition of all materials removed off-site including all materials disposed, recycled, or salvaged.

A.2 Refer to section 01720 "Project Closeout" for general project record submittal requirements.

\subsection{QUALITY ASSURANCE}

Conform to and comply with DIS Safety Orders when trenching and backfilling.

\section{PART 2 PRODUCTS}

\subsection{MATERIALS FOR DISPOSAL}

A. Materials designated for disposal must be disposed of at the Class II (or may be referred to as Class 2) Waste Management Unit at the Altamont Landfill located in Alameda County, California. Class II landfill requirements are defined by CCR Title 27. Materials for disposal include the following:

A.1 Impoundment sludge, sand ballast, and leachate collection sand layer.

A.2 Any contaminated clay liner and subgrade soils as determined by the University.

A.3 All piping designated for removal.

A.4 The concrete vault and storage drum.

A.5 All appurtenant structures within the impoundments liner limits including, but not limited to the wooden stairways, rip-rap within the impoundments, and the sampling apparatus in the upper impoundment.

A.6 Geosynthetic liner components including the geomembrane and geotextile/geofabric liners.

A.7 Lysimeters and associated tubing.

B. Submit receipts of disposal for all materials that are disposed of.

2.02 MATERIALS FOR SALVAGE

A. Materials designated for salvage may be recycled, re-used off-site, sold for reuse, or disposed of at the Class II of Class III (or may be referred to as Class 2 or 3) Waste Management Unit at the Altamont Landfill located in Alameda County, California. 
Class II or Class III landfill as defined by CCR Title 27. These materials include the following:

A.1 Traffic/utility boxes and wiring located outside of the impoundment liner limits.

A.2 Concrete stairway landing located outside of the impoundment liner limits.

A.3 CMP gutters located outside of the impoundment liner limits.

\section{PART 3 EXECUTION}

\section{$3.01 \quad$ EXAMINATION}

A. Verify that no free liquids remain in the sand ballast/sludge, concrete vault, or storage drum prior to disposal. Notify the University of the presence of any free liquids.

B. By starting the work of this section, the Subcontractor warrants that it has examined and verified that the existing conditions comply with the provisions of the preceding paragraph of subpart 3.01.

C. Notify the University of unexpected subsurface conditions, and discontinue work in affected area until notified to resume work.

\subsection{PROTECTION}

A. Protect trees, shrubs, lawns, and other features remaining as a portion of final landscaping.

B. Protect bench marks, existing structures, fences, sidewalks, paving, and curbs from equipment and vehicular traffic.

C. Maintain and protect above and below grade existing utilities scheduled to remain, which pass through or near the work area.

D. During construction, keep embankments and excavations shaped and drained. Maintain effective drainage at all times in adjacent ditches and drains.

3.03 PREPARATION

A. Identify required lines, level, contours, and datum.

B. Identify known underground utilities. Employ the services of an underground locator service to locate and mark all underground utilities before starting any excavation or trenching.

C. Notify the University 48 hours in advance when ready to abandon existing utility lines and to reconnect utilities. 
3.04 DEMOLITION, SALVAGE AND DISPOSAL

A. Do not disturb areas outside the limits of grading shown on the plans.

B. Excavate soil required for removal of utility piping following the excavation requirements of Section 02200.

C. Contain and stockpile excavated liner materials within the impoundment limits until it is loaded in trucks for disposal.

D. Prior to removal of the sludge, sand ballast and leachate collection sand layers from the site, the Subcontractor shall excavate samples of each layer at the University's direction. The University shall complete waste characterization testing of these samples prior to their removal from the site. The Subcontractor's schedule shall allow 6 weeks for the waste characterization sampling and testing to be completed after each of the samples are excavated.

E. After the Subcontractor demolishes all concrete structures, the University will sample the concrete to determine if the concrete is clean. The subcontractor shall not remove the concrete from the site until the University authorizes the removal of the concrete. The Subcontractor's schedule shall allow 2 weeks for the concrete testing to be completed after the samples are obtained.

F. After the sludge, sand ballast, and leachate collection sand layers are removed, the Subcontractor shall excavate clay sample pits as indicated in the Sampling and Analysis Plan and allow the University to obtain samples of the excavated clay and subgrade materials. The University will complete analytical testing of the clay and subgrade materials to verify that clean closure has been achieved. The subcontractor shall include a six-week period in the construction schedule to allow for sampling and analysis of the clay liner and its underlying native soils. However, the subcontractor shall not proceed with the work until the CVRWQCB has reviewed the analytical results and concurred that the surface impoundments can be clean closed.

G. Only excavate and dispose of clay and subgrade materials authorized by the University. Clay and subgrade materials removed and disposed of without the University's authorization shall not be reimbursed. The Subcontractor shall be responsible for all costs associated with the unauthorized excavation, removal and disposal of materials.

H. Do not intermix stockpiles of material to be salvaged with material designated for disposal. In the event salvaged materials are intermixed with materials designated for disposal, all intermixed salvaged materials shall be disposed of at a Class 2 Waste Management Unit as defined by CCR Title 27 at no additional cost to the University.

I. Implement dust control measures as necessary to prevent nuisance dust emissions.

J. Tarp all truck loads containing soil. 
3.05 FIELD QUALITY CONTROL

A. Provide for visual inspection of surfaces.

B. The University will employ and pay for the services of an independent testing laboratory in accordance with section 01400 "Quality Control” to collect soil samples for analytical testing necessary for clean closure certification. The proposed number and location of tests are described in the Sampling and Analysis Plan.

\subsection{CLEANING}

Remove surplus demolition materials from Site 300 in accordance with section 01010 “Administrative Requirements.”

\section{END OF SECTION}


This page intentionally left blank 
SECTION 02200 — EARTHWORK

\section{PART 1 GENERAL}

1.01 SECTION INCLUDES
A. Site excavation
B. Backfilling
C. Compaction
1.02 RELATED SECTIONS
A. Section 01400 “Quality Control”
B. Section 02061 “Impoundment Demolition, Salvage, and Disposal”
1.03 REFERENCES

A. The following documents form a part of these specifications to the extent stated herein.

B. State of California Code of Regulations (CCR)

B.1 CCR Title 8 Industrial Relations; Chapter 4 - Division of Industrial Safety (DIS):

SubCh 4. Construction Safety Orders

SubCh 5. Electrical Safety Orders

SubCh $7 . \quad$ General Industry Safety Orders

C. State of California (CAL)

C.1 CAL Labor Code Div 5: Safety in Employment

Ch 9. Miscellaneous Labor Provisions:

Sec 6705. Protection of Workers Excaving Trenches

Sec 6707. Call for Bids On Government Contracts

Requiring Excavations to Contain Item for Protection of Workers

D. State of California, Department of Transportation (CALTRANS)

D.1 CALTRANS Manual of Test

D.2 CALTRANS Standard Specifications:

Sec 19 Earthwork

Sec 26 Aggregate Bases 
E. $\quad$ ASTM International (ASTM)

E.1 ASTM C $136 \quad$ Method for Sieve Analysis of Fine and Coarse Aggregates

E.2 ASTM D 1557 Method for Laboratory Compaction Characteristics Using Modified Effort (56,000 ft-lbf/ft3)

E.3 ASTM D 2419 Method for Sand Equivalent Value of Soils and Fine Aggregate

F. Sampling and Analysis Plan, Site 300 Surface Impoundments Closure, Lawrence Livermore National Laboratories, September 2004.

\section{$1.04 \quad$ SUBMITTALS}

A. Submit project record documents under provisions of section 01300 "Submittals".

A.1 Project Record Documents: Provide as-built data, field measured in both vertical and horizontal positions to within $1 / 4$-inch.

A.2 Surface Survey: Provide a surface survey reflecting all construction changes to the design drawings and ground contours. Indicate ground surface changes at contour intervals consistent with the design drawings.

A.3 Field Points: Provide an ASCI file of all surveyed field points, including field log files in either hard or electronic copy.

A.4 Refer to section 01720 "Project Closeout" for general project record submittal requirements.

1.05 QUALITY ASSURANCE

Conform to and comply with DIS Safety Orders when trenching and backfilling.

\section{PART 2 PRODUCTS}

\section{$2.01 \quad$ FILL MATERIALS}

A. Backfill: Material free of organic or other foreign matter; graded free of lumps and rock larger than 3 inches in any dimension; and approved by the University for backfill. Subcontractor may use excavated materials that are not contaminated and which have been approved by the University. Sludge, sand ballast, leachate collection sand layer, and any contaminated clay liner and subgrade soils are strictly prohibited for reuse as backfill materials.

B. Imported Sand Bedding: Material meeting the requirements of Sand Bedding per Section 19-3.025B of the Caltrans Standard Specifications. 


\section{PART 3 EXECUTION}

\subsection{EXAMINATION}

A. Verify that earth fill and imported sand bedding are approved by the University.

B. Verify that areas to be backfilled are free of debris, ice, or water, and ground surfaces are not frozen.

C. Verify that the University has completed soil analytical testing to confirm that the demolition work under Section 02061 has resulted in clean closure by the removal of all adverse chemical constituents. No earthwork activities, exclusive of the demolition required under Section 02061, shall commence until the University has certified that the impoundments are clean-closed.

D. By starting the work of this section, the Subcontractor warrants that it has examined and verified that the existing conditions comply with the provisions of the preceding paragraphs of subpart 3.01.

E. Notify the University of unexpected subsurface conditions, and discontinue work in affected area until notified to resume work.

\subsection{PROTECTION}

A. Protect trees, shrubs, lawns, and other features remaining as a portion of final landscaping.

B. Protect bench marks, existing structures, fences, sidewalks, paving, and curbs from equipment and vehicular traffic.

C. Maintain and protect above and below grade existing utilities scheduled to remain, that pass through work area.

D. During construction, keep embankments and excavations shaped and drained. Maintain effective drainage at all times in adjacent ditches and drains.

3.03 PREPARATION

A. Identify required lines, level, contours, and datum.

B. Identify known underground utilities. Employ the services of an underground locator service to locate and mark all underground utilities before starting any excavation or trenching.

C. Notify the University 48 hours in advance when ready to abandon existing utility lines and to reconnect utilities. 


\subsection{EXCAVATION AND TRENCHING}

A. Do not disturb areas outside the limits of grading shown on the plans.

B. Machine slope banks to angle of repose or less until shored.

C. Excavate subsoil required for removal of utility piping.

D. Keep one side of the trench completely free of excavated material and on the other side, place the excavated material sufficiently far away from the trench centerline so that the toe of the pile of excavated material is at least 2 feet from the edge of the trench.

E. Correct unauthorized excavation at no additional cost to the University. Bring back excavation below that required by these specifications or indicated by the drawings to the correct grade with imported sand fill.

F. $\quad$ Stockpile excavated material in areas designated on site in accordance with section 01210 "Administrative Requirements" for University testing. Final disposition of material is dependent on test results. Refer to the subpart entitled, "Salvable and Excess Materials" in section 01010 "Administrative "Requirements" for further information.

G. At the direction of the University or its authorized representative, the Subcontractor shall excavate pits through the clay liner to a maximum depth of 4 feet as required in the Sampling and Analysis Plan. The University will obtain soil samples at 3 discrete depths for analytical testing. At the completion of the sampling, the Subcontractor shall ensure the sample pits are a minimum of 2 feet in width and 6 feet in length throughout the depth of the clay liner sample pits. The excavated clay liner shall be stockpiled adjacent to the pit until the University certifies clean closure.

H. Subcontractor is responsible for implementing dust control during all excavation and backfilling activities as necessary to prevent fugitive dust emissions.

\subsection{BACKFILLING}

A. Do not commence with any backfilling until the University certifies clean-closure.

B. Place sand bedding backfill in the clay liner pits. Sand bedding should be compacted by tamping with a backhoe bucket in 12-inch thick maximum lifts.

C. Backfill areas to contours and elevations. Use unfrozen materials.

D. Backfill systematically, as early as possible, to allow maximum time for natural settlement. Do not backfill over porous, wet, or spongy subgrade surfaces. 
E. $\quad$ Spread backfill material in layers not exceeding 0.7 feet before compaction; in trenches layers shall not exceed 0.5 feet.

F. Maintain optimum moisture content of backfill materials to attain required relative compaction density of 87\%, as determined by ASTM D 1557.

G. Employ a placement method so not to disturb or damage remaining utilities in trenches.

H. Subcontractor is responsible for implementing dust control during all excavation and backfilling activities as necessary to prevent nuisance dust emissions.

\subsection{TOLERANCES}

Top Surface of Backfilling: +/- 1.0 foot of design elevations while maintaining grades within $+/-0.5 \%$. For example, a $6 \%$ final design grade must have a final asbuilt grade of between $5.5 \%$ and $6.5 \%$ with a maximum elevation deviation of one foot from design elevation. The intent in design elevation tolerance is to provide flexibility in grading to ensure an overall soil balance is achieve such that no soil export or import is required for grading.

\subsection{FIELD QUALITY CONTROL}

A. Provide for visual inspection of bearing surfaces.

B. The University will employ and pay for the services of an independent testing laboratory in accordance with section 01400 "Quality Control” to make compaction tests at each subgrade layer to determine in-place relative density, to establish and maintain quality control of the work in progress, and to give written certification of compliance with the requirements of these specifications. The proposed number and location of tests for each subgrade layer will be determined by the University.

C. When tests made by the testing laboratory show a relative compaction below that required, the limits of inadequate compaction shall be established by the University. Remove material or scarify to the required depth and recompact. The Subcontractor shall bear the costs of recompaction and retesting of inadequately compacted fill.

\subsection{CLEANING}

Remove surplus backfill materials from Site 300 in accordance with section 01010 "Administrative Requirements."

\section{END OF SECTION}


This page intentionally left blank 
SECTION 02940 — EROSION CONTROLS

\section{PART 1 GENERAL}

1.01 SECTION INCLUDES
A. Hydroseeding
B. Straw Wattles
$1.02 \quad$ RELATED SECTIONS

A. Section 02200 "Earthwork"

1.03 REFERENCES

A. The following documents form a part of these specifications to the extent stated herein.

B. State of California Code of Regulations (CCR)

B.1 CCR Title 8 Industrial Relations; Chapter 4 - Division of Industrial Safety (DIS):

SubCh 4. Construction Safety Orders

SubCh 5. Electrical Safety Orders

SubCh $7 . \quad$ General Industry Safety Orders

C. State of California (CAL)

C.1 CAL Labor Code Div 5: Safety in Employment

Ch 9. Miscellaneous Labor Provisions:

Sec 6705. Protection of Workers Excaving Trenches

Sec 6707. Call for Bids On Government Contracts Requiring Excavations to Contain Item for Protection of Workers

D. LLNL Storm Water Pollution Prevention Plan

\section{$1.04 \quad$ SUBMITTALS}

A. Submit project record documents under provisions of section 01300 "Submittals".

A.1 Project Record Documents: Provide as-built data, field measured in both vertical and horizontal positions to within $1 / 4$-inch.

A.2 Refer to section 01720 "Project Closeout" for general project record submittal requirements. 


\section{PART 2 PRODUCTS}

\section{$2.01 \quad$ STRAW WATTLES}

A. Straw wattles shall be manufactured with rice straw and be wrapped in a biodegradable tubular wrap consisting of burlap or approved equivalent.

B. Straw wattles shall be 9-inches in diameter and supplied in continuous 25-foot segments.

\subsection{HYDROSEEDING}

A. Fertilizer shall be commercial fertilizer used in a pelleted or granular form and shall be 16 percent nitrogen, 20 percent phosphoric acid, 0 percent soluble potash, and a minimum 12 percent sulfur. Apply at a rate of 500 pounds/acre.

B. Tackifier shall be Terra Tack TR or equivalent.

C. $\quad$ Seed

C.1 Seed required to be labeled under the California Food and Agriculture Code, shall be labeled by the vendors supplying such seed. Seed shall have been tested for purity and germination not more than 15 months prior to the application of such seed. The test results from such seed testing shall be delivered to the University prior to applying the seed.

C.2 Seed labels furnished by the seed vendors supplying such seed shall indicate the purity and germination as determined by such seed testing. Seed not required to be labeled under the California Food and Agricultural Code shall be tested for purity and germination by a seed laboratory certified by the Association of Official Seed Analysts, or a seed technologist certified by the Society of Commercial Seed Technologists. The percentage of seed germination shall include the germination percentage of any hard seed.

C.3 Legume seed shall be pellet-inoculated with a viable bacteria compatible for use with that species of seed. All inoculated seed shall be labeled to show the weight of seed, the date of inoculation, and the weight and source of inoculant materials. Inoculants shall be added at the rate of 2 pounds of inoculant per 100 pounds of legume seed. 
C.4 Seed shall consist of the following:

\begin{tabular}{|l|c|c|}
\hline \multicolumn{1}{|c|}{$\begin{array}{c}\text { Vegetation } \\
\text { Name (common) }\end{array}$} & $\begin{array}{c}\text { Application } \\
\text { Rate } \\
\text { (lbs/acre) }\end{array}$ \\
\hline Regreen & Elymus X Triticum & 24 \\
\hline Three Weeks Fescue & Vulpia microstachys & 6 \\
\hline Blue Wildrye & Elymus glaucus & 6 \\
\hline Purple Needlegrass & Nassella pulchra & 4 \\
\hline California Oniongrass & Melich californica & 3 \\
\hline California Sage (brush) & Artemisia califonica & 3 \\
\hline Black Sage (bush) & Salvia mellifera & 3 \\
\hline Coyote Bush & Baccharis piluaris & 4 \\
\hline Native Pine Bluegrass & Poa scabarella/scunda & 3 \\
\hline
\end{tabular}

D. Mulch shall consist of one of the following:

D.1 Paper fiber mulch mixed at a rate of 50 pounds of material per 100 gallons of water and applied at a rate of 750 pounds per acre.

D.2 Wood fiber mulch mixed at a ratio of 30 to 33 pounds of dry material per 100 gallons of water and applied at a rate of 1,500 to 2,000 pounds per acre.

\section{PART 3 EXECUTION}

\subsection{EXAMINATION}

A. Verify that all work under section 02200 is completed prior to the installation of straw wattles or the application of hydroseeding.

\subsection{STRAW WATTLES}

A. Install as shown in the plans. Proper site preparation is essential to ensure complete contact of the wattle with the soil.

B. Install generally parallel to slope contours. Use a minimum of 8 wooden stakes per 25-foot long straw wattle segment.

C. The slope shall be prepared to receive the surface mulching/seeding treatment prior to installing the wattles.

D. Remove all rocks, clods, vegetation or other obstructions so that the installed wattles will have direct contact with the soil. 
E. A small, 3- to 5-inch deep trench shall be excavated on the slope contour and perpendicular to water flow. Soil from the excavation shall be placed down-slope next to the trench.

F. Install the wattles in the trench, insuring that no gaps exist between the soil and the bottom of the wattle. The ends of adjacent wattles shall be tightly abutted so that no opening exist for water or sediment to pass through. Alternately, wattles may be lapped 6-inches to prevent sediment passing through field joints.

G. Wooden stakes shall be used to fasten the wattles to the soil. When conditions warrant, a straight metal bar shall be used to drive a "pilot-hole" through the wattle and into the soil.

H. Wooden stakes shall be placed 6-inches from the wattle end and angled towards the adjacent wattle. Additional stakes shall be spaced 3 to 4 feet apart along the full length of each wattle. Stakes shall be driven so that less than 1 to 2 -inches of the stake is exposed above the wattle.

I. Terminal ends of the wattles may be dog-legged up the slope to ensure containment and prevent channeling of sedimentation.

J. Backfill the upslope length of the wattle with the excavated soil and compact.

K. $\quad$ Care should be taken during installation to avoid damage occurring to the wattle as a result of the installation process. Any wattles damaged during placement shall be replaced as directed by the University, at the subcontractor's expense.

L. The wattles shall be inspected after installation to insure that they are trenched-in and that no gaps exist under the wattles or between adjacent ends.

\subsection{HYDROSEEDING}

A. Straw wattles shall be installed and inspected by the University prior to the completion of hydroseeding.

B. Mix seed and fertilizer per manufacturer's recommendations and apply at the specified rates using hydraulic methods. Seed shall be applied between October 1, 2005 and October 30, 2005

C. After applying the seed, mix the mulch per manufacturer's recommendations and apply at the specified rate.

D. Apply a tackifier to mulch surface per manufacturer's recommendations.

E. Use commercially available tracers with the seed mix and tackifier. 
3.04 CLEANING

Remove surplus backfill materials from Site 300 in accordance with section 01010 "Administrative Requirements."

\section{END OF SECTION}


This page intentionally left blank 